\title{
Community Cellular Networks: An Experimental Evaluation in the Philippines
}

\author{
Pre-analysis Plan*
}

\author{
Joshua Blumenstock $^{\dagger} \quad$ Niall Keleher ${ }^{\dagger} \quad$ Arman Rezaee $^{\ddagger} \quad$ Erin Troland $^{\S}$
}

August 7, 2019

\begin{abstract}
Despite the rapid expansion of mobile coverage in the developing world, roughly $10 \%$ of the world's population still lives beyond the reach of a cell tower and all of the platforms, products, and services that cell towers make possible. This study investigates the impact of a new type of cellular connectivity designed specifically to address the "last mile" problem: the Community Cellular Network. Built on open-source technology first developed by researchers at UC Berkeley, the Community Cellular Network provides community-owned cellular infrastructure at one-tenth of the cost of traditional mobile towers.

Our goal is to develop a deeper understanding of the social and economic impacts of first-time access to a cellular network in isolated communities in the Philippines. We use a two-stage randomized control trial in which we (i) randomly assign villages to receive or not receive a new cellphone tower; and (ii) within treated villages, randomize the price that households paid to access these networks. This pre-analysis plan describes how we plan to study the impacts of cellular access on social network structure, and several social and economic outcomes.
\end{abstract}

\footnotetext{
*We are grateful to the following partners for project implemenation: Innovations for Poverty Action, University of the Philippines Diliman, and University of Washington. This project was funded by the Bill and Melinda Gates Foundation, NetHope, USAID, the Center for Effective Global Action, and University of California Berkeley Hellman Fellows Fund.

${ }^{\dagger}$ University of California, Berkeley

$\ddagger$ University of California, Davis

$\S$ Federal Reserve Board of Governors
} 


\section{Contents}

1 Introduction $\quad 4$

1.1 Research Questions . . . . . . . . . . . . . . . . . . 5

2 Experimental Design $\quad 5$

2.1 Experiment Overview . . . . . . . . . . . . . . . . . 5

2.2 Baseline Data Collection . . . . . . . . . . . . . . . . . 7

2.3 Randomization and Installation of CCN Sites . . . . . . . . . . . . . 8

2.3.1 Site Selection . . . . . . . . . . . . . . . . 8

2.3.2 CCN Tower Installation . . . . . . . . . . . . . . . . . . 9

2.3.3 Customer Registration and Tower Launch . . . . . . . . . . . . . . . 11

2.3.4 Mobile Network Data Collection . . . . . . . . . . . . . . . . . . 12

2.4 Random Assignment to Promotions . . . . . . . . . . . . . . . . . . . . . . 12

2.5 Data on Network Signal Strength . . . . . . . . . . . . . . . . . . . . . . . . . . . . . 14

2.6 Endline Data Collection . . . . . . . . . . . . . . . . . . . . . 14

3 Primary Hypotheses and Outcomes 15

3.1 Family A: Access to communications . . . . . . . . . . . . . . . 16

3.2 Family B: Social networks and communication . . . . . . . . . . . . 16

3.3 Family C: Informedness . . . . . . . . . . . . . . . . . . . . 17

3.4 Family D: Economic outcomes . . . . . . . . . . . . . . . . . . . 18

3.5 Important control variables . . . . . . . . . . . . . . . . 20

4 Empirical Analysis $\quad 21$

4.1 Balance Checks . . . . . . . . . . . . . . . . . . . . 21

4.2 Primary Outcome Treatment Effects . . . . . . . . . . . . . . . . . . . . . . . . . . . . . . . . 22

4.2.1 Village-level intent to treat . . . . . . . . . . . . . . . . 22

4.2.2 Household-level treatment-on-the-treated by cellular network access and mobile phone useage . . . . . . . . . . . . . . . . . 22

4.3 Primary Outcome Heterogeneous Treatment Effects . . . . . . . . . . . . 23

4.4 Estimating p-values . . . . . . . . . . . . . . . . . . . 23

4.5 Multiple hypothesis test corrections . . . . . . . . . . . . . . . . . . 24

4.6 Unit of analyses . . . . . . . . . . . . . . . . . . . . . . . . . . . . . . . . . . . . . . . . . . . . .

4.7 Sample attrition . . . . . . . . . . . . . . . . . . . 24

5 Testing Social Networks as a Mechanism 25

6 Demand for Community Cellular Access 26

7 Secondary Hypotheses and Analyses $\quad 27$

7.1 Secondary Family A: Political economy . . . . . . . . . . . . . . . 27

7.2 Secondary Family B: Intra-household decision-making . . . . . . . . . . . . . 28 
8 Appendix 33

8.1 VBTS Konekt Network . . . . . . . . . . . . . . . . . . . . . . . . . . . . 33

8.1 .1 Site Launch Manual . . . . . . . . . . . . . . . . . . . 34

8.1.2 Script for Registration . . . . . . . . . . . . . . . . . . . . . 42

8.1.3 Customer Agreement . . . . . . . . . . . . . . . . . . . 43

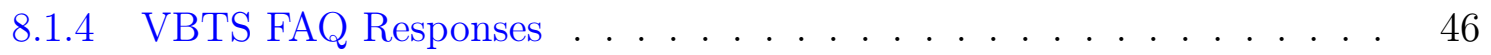

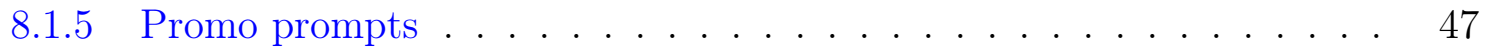

8.1.6 Promotional Materials . . . . . . . . . . . . . . . . . . 48

8.2 Baseline Household and Adult Survey . . . . . . . . . . . . . . . . . 50

8.3 Endline Household and Adult Survey . . . . . . . . . . . . . . . . . 67

8.4 Endline Community Survey . . . . . . . . . . . . . . . . . 96 


\section{Introduction}

In the past decade, over two billion individuals in developing countries have started using mobile phones for the first time; a further 710 million subscribers are projected to adopt by 2025 (GSMA, 2019). The vast majority of new mobile phone subscribers will live in developing countries, more than half will be in the Asia Pacific region (GSMA, 2018). Despite the rapid expansion, roughly ten percent of the world's population still lives without mobile phone coverage. Bridging this "last mile" connectivity gap requires innovative technological solutions and new business models since commercial operators do not see these marginalized communities as commercially viable.

To address this "last mile" connectivity gap, researchers from the University of California, Berkeley developed a new mobile phone technology — the Community Cellular Network $(\mathrm{CCN})$ - that provides local coverage at one-tenth of the cost of traditional mobile towers. The CCN is explicitly designed for rural settings with intermittent power and intended to be owned and maintained by local community members with modest technical training (Heimerl and Brewer, 2010). Over the past several years, we collaborated with developers of the CCN and researchers at the University of the Philippines-Diliman, to deploy CCNs in several remote and isolated villages in the Philippines.

A fundamental premise of this effort is that Community Cellular Networks have the power to unlock economic opportunities and reduce the economic vulnerability of historically marginalized populations. CCNs bring affordable mobile connectivity to rural, isolated regions of the world. The CCN technology, in turn, creates options for people to develop and expand their social connections within and outside of the community. With more robust social networks, these individuals may access new opportunities for social and economic interaction, including better access to information about employment and migration, entrepreneurial activities, civic engagement, and early warning about predictable adverse shocks. Platforms, products, and services built on top of cellular connections can amplify these impacts.

This particular theory of change is motivated by results described in the academic research literature. Aker and Blumenstock (2015) summarize much of this literature. In short, prior work has mainly focused on how mobile phones impact the flow of information in agricultural markets (Aker, 2010; Jensen, 2007; Muto and Yamano, 2009; Labonne and Chase, 2009). These studies thus generally indicate a positive impact of mobile phones on the efficiency of agricultural markets, and a related body of research is emerging around the economic impacts of mobile financial services (Blumenstock, Eagle, and Fafchamps, 2016; Suri and Jack, 2016). However, very little work has been done to understand how connecting communities affects social networks and broader economic activities of households.

Thus, while the existing literature motivates our work, there are significant gaps in the current state of knowledge. Critically, the premise and theory of change articulated here has never been carefully tested. To date, almost no quantitative evidence exists on the direct consequences of first-time access to cellular networks - let alone to Community Cellular Networks. Furthermore, to date, we are not aware of anyone who has performed an RCT to understand the impacts of cellular access. This is presumably due to the immense level of coordination between academic researchers, government regulators, commercial operators, and local communities that is required to manage a randomized deployment of cellular towers. 
By leveraging a new low-cost technology, and by cultivating strong local relationships, we created a truly unique opportunity to conduct a randomized control trial of Community Cellular Networks in a set of 14 geographically isolated villages in the Aurora province of the Philippines (See Section 2.1 below). The randomized control trial had two stages. The first was a village-level treatment, where a "staggered roll-out" design randomly determined which seven of the 14 villages received a CCN between September 2017 and September 2019, as well as the timing of each installation. The second stage was a household-level treatment, through which we reduced the cost of making phone calls and sending text messages to specific households. This second stage will allow us to precisely estimate the demand for cellular connectivity (and all that comes with it) and will create random household-level variation in communication costs, which we can in turn use to identify the impact of connectivity on other outcomes.

\section{$1.1 \quad$ Research Questions}

Our primary research questions are:

1. Can community cellular networks be used to increase access to communications for households?

2. What is the impact of first-time cellular connectivity on social networks and communication across these networks?

3. What is the impact of first-time cellular connectivity on informedness of households?

4. How does increased connectivity, and the networks this foster, affect key social and economic outcomes, including:

- Market access

- Migration

- Remittances and risk-sharing

- Income and expenditures

- Disaster preparedness

- Subjective well-being

5. What is household willingness-to-pay for use of a cellular network (load) conditional on having access to a cellular tower?

\section{Experimental Design}

\subsection{Experiment Overview}

Working with researchers at the University of the Philippines Diliman, we identified candidate sites for CCNs in the Philippines - areas that, as of December 2016, lacked cellular coverage but were not so remote as to make the logistics of research infeasible. We identified 


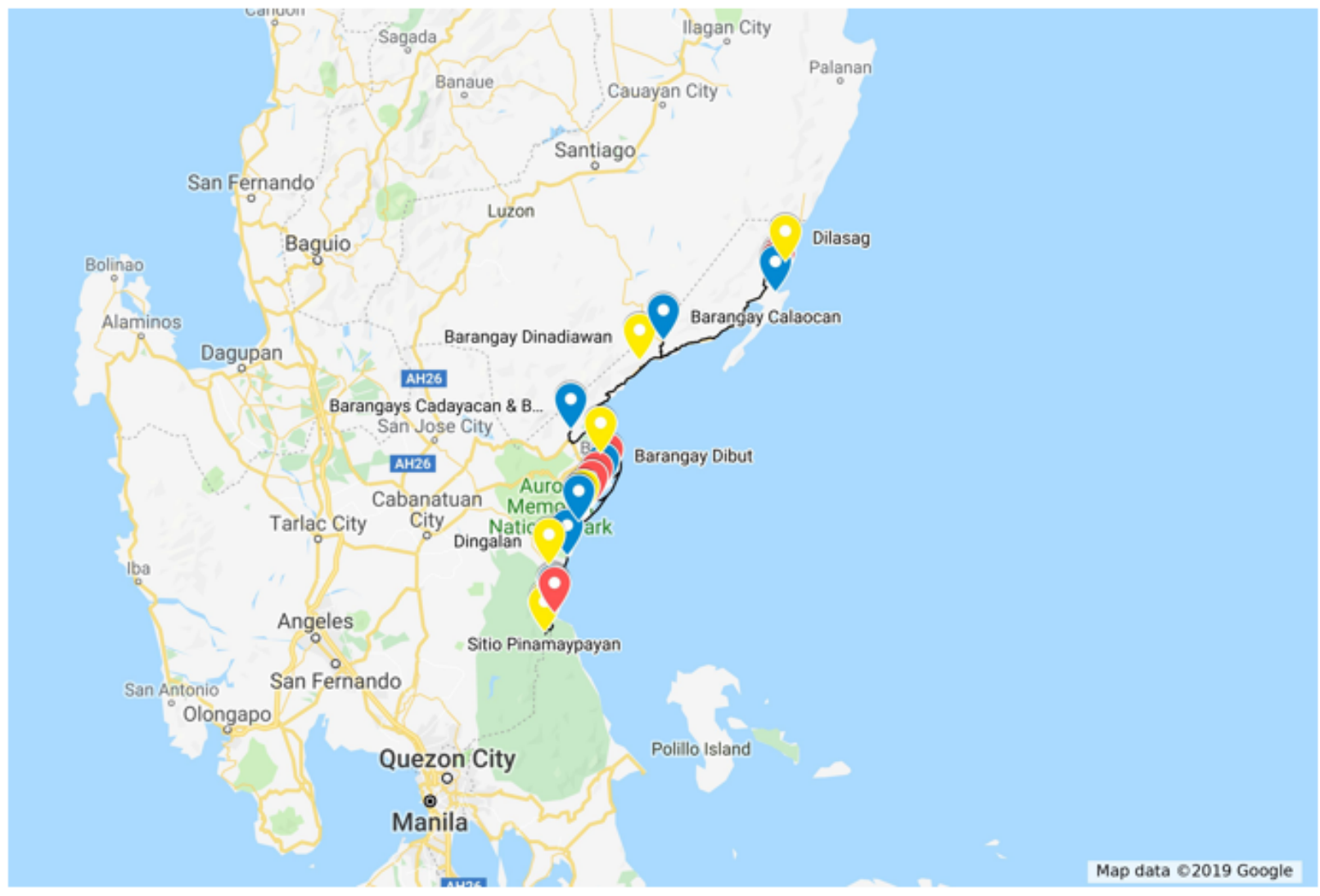

Figure 1: Location of project sites

14 candidate sites along the west coast of the largest island in the Philippines, Luzon. All sites are located in the Province of Aurora. Sites are villages, or 'sitios' using the Philippines term for the lowest-level administrative unit, located near or along the coast. Many of the potential sites are located in sea coves only accessible by boat. Typhoons frequently hit Aurora. A typhoon had badly damaged several potential sites just weeks before our first scoping visit to the area. During typhoon season, coves are often inaccessible for multiple days.

The main regional town in the area, Baler, is up to several hours away by bus or boat from the project sites. Travel to Manila requires upwards of 24 hours. Each candidate site was deemed able to support a CCN. CCN base stations transmit to a 500-meter radius, on average after accounting for variance in terrain. Field teams visited all potential sites to verify eligibility (no cellular connection at that time), determine possible logistics, and meet with local government units (LGUs). While no cellphone signal was present in the selected sites, phone communications were not entirely new to households residing in the sites. Through our baseline survey, we find that $67 \%$ of household owned a phone and a sim card. However, people needed to travel long distanced to access phone service.

Our research design consists of four stages, which are summarized in Table 1. First, we conducted a census of all households in each of the eligible 14 sites. Second, we used a matched-pairs random assignment design to select seven sites that would receive a CCN tower. The University of the Philippines team led the construction, testing, and network 
Table 1: Phases of the Experiment

\begin{tabular}{|c|c|c|}
\hline Phase & Dates & Sample Size \\
\hline Baseline & $\begin{array}{l}\text { Phase 1: } 10 \text { sites } \\
\text { July-November } 2016 \\
\text { Phase 2: } 4 \text { sites } \\
\text { March-April } 2018\end{array}$ & $\begin{array}{l}N=14 \text { sites } \\
N=2370 \text { households surveyed } \\
N=6613 \text { adults listed (age } 15-107) \\
N=3351 \text { adult surveys }\end{array}$ \\
\hline Implementation & $\begin{array}{l}\text { Phased roll out } \\
\text { September } 2016 \text { - } \\
\text { September } 2019\end{array}$ & $\begin{array}{l}N=7 \text { treatment sites } \\
N=1131 \text { eligible households } \\
N=3064 \text { eligible adults } \\
N=2653 \text { registered accounts }\end{array}$ \\
\hline Promotions & $\begin{array}{l}\text { Phased roll out } \\
\text { September } 2018 \text { - } \\
\text { March } 2019\end{array}$ & $\begin{array}{l}N=1131 \text { eligible households } \\
N_{T 0}=187-\text { No promotions } \\
N_{T 1}=191-\text { Free phone credit } \\
N_{T 3}=183-\text { Local discount } \\
N_{T 3}=186-\text { Local discount } \\
\quad \text { plus free credit } \\
N_{T 4}=191-\text { Long distance discount } \\
N_{T 5}=193-\text { Long distance discount } \\
\quad \text { plus free credit }\end{array}$ \\
\hline Endline & May - August 2019 & $\begin{array}{l}N=2370 \text { households (target) } \\
N=4740 \text { adult surveys (target) } \\
N=[\text { TBD }] \text { valid household surveys } \\
N=[\text { TBD }] \text { valid adult surveys } \\
N=14 \text { community surveys (target) }\end{array}$ \\
\hline
\end{tabular}

management in each of the seven treatment sites. Third, we carried out a household-level randomized experiment in which three promotional treatments were tested: (1) free phone credit, (2) discounts on local calls and text messages, and (3) discounts on long-distance (out-of-network) calls and text messages. We randomly assigned households to one of six experimental groups, as noted in the Promotions row of Table 1. Fourth, the study will conclude with an endline survey of all households in the 14 sites.

\subsection{Baseline Data Collection}

Before the installation of CCN towers, we conducted a socio-economic survey of all households in the 14 potential sites for a CCN. A team of surveyors made a door-to-door visit to request voluntary consent from household heads to participate in the research study. As such, we aimed to complete a full census of each site. To ensure the near-complete census of the households, we leveraged a household listing frame from community health workers and consulted with local leaders to accurately identify all unique households within a site.

Across all 14 potential sites, surveyors conducted a total of 2,370 household surveys. Some households were unavailable at the time of the initial baseline. In total, $95 \%$ of baseline surveys were conducted before the CCN launch (123 baseline surveys were conducted 
on the day of launch). ${ }^{1}$ The household survey consisted of modules about household demographic composition, asset ownership, and economic activity (see Appendix Section 8.2 for the instrument and consent form). We collected demographic, education, and labor participation information though a household roster. In total, 6,613 adults (15 years or older) were enumerated. All respondents provided voluntary consent to participate in the study.

In each household surveyed, we conducted individual-level surveys with at least one adult per household. Surveyors were instructed to attempt to complete two adult surveys, with priority given to interviews with the head of household and the spouse of the head of the household. All attempts were made to interview one woman and one man per household when at least two members of differing gender were available. The core modules contained within the adult survey were a travel diary and a social network module (pp 9-15 of Appendix Section 8.2). In total, 3,351 adult surveys were completed at the time of the baseline. Women comprise 62 percent of the baseline adult survey respondents.

As noted in Table 1, baseline data collection was conducted in two phases. An initial ten sites were identified and surveyed between July and November 2016. Later, in order to increase the number of $\mathrm{CCN}$ installations to seven, an additional four sites were identified and surveyed between March and April 2018.

\subsection{Randomization and Installation of CCN Sites}

\subsubsection{Site Selection}

Following Greevy et al. (2012), we used Reweighted Mahalanobis distance matching to isolate pairs of sites with similar characteristics. Pairwise distances were calculated using the following nine site-level characteristics:

1. Count of households

2. Mean household wealth index

3. Proportion of households that send or receive remittances

4. Proportion of households that own a cellphone

5. Mean number of social network contacts outside of the barangay

6. Proportion of households reporting fishing as their main source of income

7. Proportion of adult survey respondents that report receiving information through mobile phone on a monthly or more regular basis

8. Proportion of adults that work or attend school outside of the site

9. Municipality where the site is located

\footnotetext{
${ }^{1}$ Our primary analysis will rely on those households that were surveyed before the CCN launch.
} 
Site characteristics were given equal weight when calculating the Mahalanobis distances. ${ }^{2}$ Using the resulting distance matrix, we conducted nonbipartite matching to identify pairwise matches that minimize the sum of distances between pairs. We randomized the order of pairs then assigned one site per pair to receive a CCN tower.

Since baseline data collection occurred in two phases, we performed the treatment assignment twice. Following Phase 1 of the baseline data collection, we conducted treatment assignment using the initial ten sites surveyed in 2016 (see 2.2). This initial assignment provided four sites to receive CCN tower installations. After Phase 2 of the baseline survey, we re-ran the matching and treatment assignment using the two sites not used in the first treatment assignment plus the four sites surveyed in Phase 2.

\subsubsection{CCN Tower Installation}

A team of engineers from the University of the Philippines was responsible for installing, testing, and maintaining the CCNs. The implementation of the CCN was named the VBTS Konekt Network. ${ }^{3}$ The range of each CCN tower has an upper bound of 500-meter radius. As such, the towers were locally targeted by design. Barela et al. (2016) provides a thorough description of the VBTS Konekt Network technical design. The VBTS tower connects to a major Philippine mobile network operator's cellphone towers. We refer to this as the long-distance on-network provider. All calls and texts originating and ending on the VBTS Konekt Network are referred to as local transactions.

We provided the list of selected sites and the ordering of installations to the engineering team at the University of the Philippines (UP). The UP team then initiated the process of procuring and transporting VBTS equipment to the treatment sites to install towers. Table 2 provides the dates of installation for each site.

UP ran network tests to ensure the stability of the network before giving its authorization to launch the tower signal to the customers. In addition, to maximize the likelihood of community support and ownership, the UP team coordinated with a local cooperative as well as retailers who would be responsible for basic maintenance and selling phone credit (referred to as "load" in the Philippines). At that point, UP facilitated a registration and launch event for the site.

\footnotetext{
${ }^{2}$ We used the $\mathrm{R}$ package, nbpMatching, from Beck, Lu, and Greevy (2016) to calculate distances and perform nonbipartite matching.

${ }^{3}$ VBTS stands for Village Base Transceiver Station.
} 
Table 2: Site Information and Key Dates

\begin{tabular}{lcccc|cccc}
\hline & \multicolumn{4}{c}{ Population } & & \multicolumn{4}{c}{ Dates } \\
\hline Site & Households & Adults & $\begin{array}{c}\text { Registered } \\
\text { Accounts }\end{array}$ & $\begin{array}{c}\text { Active } \\
\text { Accounts }\end{array}$ & $\begin{array}{c}\text { Baseline } \\
\text { End Date }\end{array}$ & $\begin{array}{c}\text { CCN } \\
\text { Installation }\end{array}$ & $\begin{array}{c}\text { Account } \\
\text { Registration }\end{array}$ & $\begin{array}{c}\text { Promotions } \\
\text { Start Date }\end{array}$ \\
\hline Site 1 - tower & 88 & 220 & 98 & 68 & $2016-10-23$ & $2017-09-13$ & $2017-09-15$ & $2018-09-01$ \\
Site 1 - control & 124 & 341 & - & - & $2016-10-23$ & - & - & - \\
Site 2 - tower & 391 & 1218 & 990 & 972 & $2016-11-06$ & $2017-10-25$ & $2017-10-27$ & $2018-09-17$ \\
Site 2 - control & 180 & 500 & - & - & $2016-09-16$ & - & - & - \\
Site 3 - tower & 182 & 502 & 376 & 296 & $2016-11-21$ & $2018-02-01$ & $2018-02-01$ & $2018-10-29$ \\
Site 3 - control & 150 & 387 & - & - & $2016-07-31$ & - & - & - \\
Site 4 - tower & 176 & 354 & 326 & 300 & $2016-07-25$ & $2018-05-30$ & $2018-06-02$ & $2018-10-29$ \\
Site 4 - control & 62 & 208 & - & - & $2016-09-03$ & - & - & - \\
Site 5 - tower & 255 & 646 & 471 & 133 & $2016-10-23$ & $2018-08-29$ & $2018-09-01$ & $2018-11-27$ \\
Site 5 - control & 513 & 1531 & - & - & $2018-04-26$ & - & - & - \\
Site 6 - tower & 55 & 138 & 137 & 68 & $2018-03-19$ & $2018-10-17$ & $2018-10-20$ & $2019-02-22$ \\
Site 6 - control & 147 & 409 & - & - & $2018-04-10$ & - & - & - \\
Site 7 - tower & 104 & 255 & 255 & 137 & $2018-03-17$ & $2019-01-25$ & $2019-01-27$ & $2019-02-22$ \\
Site 7 - control & 63 & 173 & - & - & $2018-03-23$ & - & - & - \\
\hline
\end{tabular}


Table 3: VBTS Konekt Tariff Schedule

\begin{tabular}{lr}
\hline Network Interaction Type & Tariff (PHP) \\
\hline Call from a Konekt number to another Konekt number & $1.00 /$ minute \\
Call from a Konekt number to a long-distance on-network number & $3.00 /$ minute \\
Call from a Konekt number to an long-distance off-network number & $5.50 /$ minute \\
Text from Konekt number to Konekt number & $0.25 /$ message \\
Text from Konekt number to long-distance on-network number & $0.50 /$ message \\
Text from Konekt number to long-distance off-network number & $1.00 /$ message \\
All incoming calls & FREE \\
Incoming text messages (on-network local and long-distance) & FREE \\
Incoming text messages (off-network) & NOT ALLOWED \\
\hline
\end{tabular}

\subsubsection{Customer Registration and Tower Launch}

In each treatment site, we conducted customer registration events. The event was advertised to the community at least one week in advance of the event in order to encourage high attendance. At the launch event, UP technicians described the VBTS network and the services provided by the network. In addition, all adults living in the site were eligible to collect and register a SIM card under their name. We used data from the baseline household roster to confirm the identity of VBTS customers and enable linking of data between the VBTS and baseline survey database. When an interested customer was unidentified in the baseline survey database, we required a household visit to confirm that the individual was a resident of the treatment site.

For each customer, a registration staff member explained the steps to activate a SIM card (see Appendix Section 8.1.2 for the script that was followed). VBTS Konekt SIM cards were provided for free to customers. In order to be eligible for a SIM card, a customer needed to have a functioning GSM 900 or multi-band cellphone. No phones were provided to customers by the research team. Customers were read the user agreement (see Appendix Section 8.1.3) and required to accept the terms of the agreement before receiving their SIM card. Registration staff assisted customers to activate their SIM card and inform them of their unique phone number (MSISDN). SIM cards could be replaced if they were lost or malfunctioned in which case the customer would retain the same phone number in the event of a SIM replacement. Additional SIM cards could be bought for 15 Pesos.

The VBTS Konekt Network allows for calls to and from other mobile and landline phones within the Philippines. Text messages are limited to the local Konekt network and longdistance on-network phone numbers in the Philippines. Table 3 provides the schedule of tariffs for all network interaction types. Local calls and texts are the lowest cost, on-network long-distance calls and texts are billed at a higher rate than local interactions, and offnetwork interactions are the most costly. All incoming calls and texts are free of charge to the customer; however, the calling party for incoming calls and texts are charged at standard long-distance rates. Due to regulatory restrictions, texts from off-network numbers cannot be received. Similarly, international transactions are prohibited on the VBTS Konekt Network.

Customers were informed that they could purchase phone credit through retailers based 
within the site. Each site had between one and three retailers. To promote the take-up of the network and encourage customers to try the network, all customers that activated their SIM card received five free text messages. Customers were also informed that promotions might be offered to them at a later date.

Following the launch event, UP enabled the cellular network for all activated SIM cards. The network could only works through VBTS Konekt SIM cards. Customers could purchase phone credit directly through retailers.

\subsubsection{Mobile Network Data Collection}

Call Detail Records (CDR) - logs of all transactions initiated on or incoming to the CCN - were recorded by the VBTS Konekt Network. All CDR are stored on servers at the University of the Philippines and shared with the research team. CDR capture the following basic metadata:

- Date and time of transaction

- Customer SIM card identifier (IMSI)

- Antenna identifier

- Interaction type (call, text message)

- Initiating party's phone number

- Receiving party's phone number (if call)

- Call duration (if call)

- Billable duration (if call)

- Tariff (in Philippines Pesos)

- Cost (in Philippines Pesos)

- Start Balance

- End Balance

Data are stored and backed up daily. The CDR from the VBTS Konekt Network allow us to observe individual interactions on-network (local) and out-of-network (long-distance).

\subsection{Random Assignment to Promotions}

After the VBTS Konekt Network was active for at least two months, we offered promotions to customers through a second randomized experiment. Table 4 shows the matrix of treatment assignments. The first dimension was a free credit of 100 Pesos loaded directly to the customer's balance. The second dimension was a type of tariff discount provided to customers. $50 \%$ tariff discounts were applied to either local on-network calls or long-distance 
Table 4: Promotional Treatment Groups

\begin{tabular}{|l|c|c|c|}
\cline { 2 - 4 } \multicolumn{1}{c|}{} & $\begin{array}{c}\text { No } \\
\text { Discount }\end{array}$ & $\begin{array}{c}50 \% \\
\text { Local } \\
\text { Discount }\end{array}$ & $\begin{array}{c}50 \% \\
\text { Long-distance } \\
\text { Discount }\end{array}$ \\
\hline No Free Load & 187 & 183 & 191 \\
\hline Free Load & 191 & 186 & 193 \\
\hline
\end{tabular}

Note: Numbers in cells represent household counts.

calls. All customers, including those in the promo control group, received five free longdistance text messages. To account for potential sharing of phones within the household, treatment assignment was done at the household level.

We stratified promotion treatment assignment by phone use, network size, and wealth. This stratification is shown below, where each dimension was defined as the first principal component from a PCA of the covariates listed as sub-items (data source in parentheses).

1. Above median phone usage

(a) Total call minutes (call detail records)

(b) Total text messages (call detail records)

(c) Number of SIM cards owned at baseline (baseline survey data)

2. Above median social network size (baseline survey data)

(a) Number of within-barangay social network contacts

(b) Number of outside-barangay social network contacts

(c) Proportion of social network contacts that are outside barangay

3. Above median wealth index (baseline survey data)

(a) Owns sofa set

(b) Owns refrigerator

(c) Owns television

(d) Owns DVD player

(e) Owns radio

(f) Owns satellite dish

(g) Owns motor vehicle

(h) Owns gas stove

Customers were automatically enrolled in the promotional group that they were randomly assigned. However, customers were given the option to opt-out. Promotional tariff rates were available for a minimum of 30 days per site. 
At the start of the promotional period, customers received text messages describing the promotion(s) that they received, in the local language (Tagalog). English translations of these messages are provided in Appendix X

Free 5 text messages Congratulations! Maari mo nang ma-enjoy ang Free5 promo! Meron kang libreng 5 texts sa Globe at 5 texts palabas ng ibang networks! For more info, i-text ang INFO FREE5 at $i$-send sa 555. Kung ayaw mong matanggap ang promo na ito, text REMOVE FREE5 at i-send sa 555.

Free Load: Bilang pasasalamat sa pagiging VBTS subscriber, ang iyong SIM ay makakatanggap ng libreng Php 100 e-load! Maaring magamit ang load sa pangtawag/text sa kahit anong network. Ang e-load ay matatanggap sa loob ng 72 na oras.

Local Discount: Congratulations! Maari mo nang ma-enjoy ang GoLocal promo! Sa loob ng 30 days, 50\% off ang texts at calls mula VBTS to VBTS network. For more info, text INFO to 555. Kung ayaw mong matanggap ang promo na ito, text REMOVE GL at $i$-send sa 555 .

Long Distance Discount: Congratulations! Maari mo nang ma-enjoy ang GoLongDistance promo! Sa loob ng 30 days, 50\% off ang texts at calls mula VBTS palabas ng ibang network. For more info, i-text ang INFO GLD at i-send sa 555. Kung ayaw mong matanggap ang promo na ito, text REMOVE GLD at i-send sa 555.

\subsection{Data on Network Signal Strength}

We will collect data from each site (control and treatment) that estimates the strength of mobile network signal in various locations of the site. Surveyors will load an Android phone with one of three mobile network SIM cards (Globe, Smart, and VBTS). Using the Net Monitor App, ${ }^{4}$ the surveyor will begin recording available signal for the mobile network corresponding to the SIM card. The surveyor will walk along all paths in the site, while the app continuously collects data. The main data points of interest are the mobile network operator code, frequency band type, location area code (LAC), received signal strength indicator (RSSI), Cell ID, latitude, longitude, and the absolute radio-frequency channel number (ARFCN). RSSI, the main network quality measure of interest, is a measure of the strength of the radio signal from a cellphone tower to a cellphone. RSSI ranges from -130 to $0 \mathrm{dBm}$ (Decibel-milliwatts in logarithmic scale), values closer to zero indicate a stronger signal (Rogerson et al., 2004). Typically, the network signal is considered strong at values greater than $-70 \mathrm{dBm}$. Data collection will proceed for each of the three mobile networks of interest (Globe, Smart, and VBTS). We will use spatial kriging techniques to interpolate network signal at the location of each household (Cressie, 1990).

\subsection{Endline Data Collection}

We will return to all 14 study sites between May and August 2019. Surveyors will attempt to interview all households interviewed at the time of the baseline survey. Additionally, if new households have been added to the sites since baseline, these households will also be

\footnotetext{
${ }^{4}$ https://vavsoftware.000webhostapp.com/en
} 
interviewed. The content of the endline survey can be found in Appendix Section 8.3. The household module will be administered with the head of household or the spouse of the household head. As in the baseline, we will attempt to survey two adults per household through the adult module. Priority will be placed on interviewing the same individuals surveyed at the time of the baseline. Where those individuals are unavailable, a replacement adult of the same gender will be selected at random from the same household. All respondents must provide voluntary consent to participate in the study.

\section{Primary Hypotheses and Outcomes}

\section{Overview}

First-time access to a cellular network could plausibly impact a wide range of outcomes for households in our sample. Based on our qualitative experiences interacting with villagers, and after a review of the relevant literature, we designed our survey to test four families of hypotheses. These families broadly reflect our theory of change: Provision of the CCN should dramatically lower the cost of communications, which in turn should enable people to build and strengthen their social networks. This, in turn, should increase access to information. Strengthened networks and better information, we hypothesize, should then impact economic outcomes.

To summarize, we will test four families of hypotheses: (i) access to communications, (ii) social networks, (iii) informedness, and (iv) economic outcomes. Each family contains one or more specific outcomes that we hypothesize are likely to be impacted by treatment.

Within the family access to communications, we have one hypothesis:

1. Increased access to communications

Within the family social networks, we have two hypotheses:

2. Increased social connectedness - local

3. Increased social connectedness - long-distance

Within the family informedness, we have two hypotheses:

4. Increased informedness

5. Increased disaster preparedness

Finally, within the family economic outcomes, we have five hypotheses:

6. Increased market access

7. Changed migration

8. Changed remittances and risk sharing

9. Changed income and expenditures 
10. Changed subjective well-being

Each of these 10 hypotheses will be tested with different questions from our survey instrument. These specific questions are provided below. For each question, we repeat the wording. In parenthesis, we also include the question number in the endline survey (See Appendix 8.3), the variable name that will be used in the data, and either $\beta>0, \beta<0$, or $\beta=0$ to designate whether our priors suggest a one-sided or two-sided hypothesis test for the outcome. Finally, we include any additional information about how survey responses will be coded if such is unclear from the question. Indicators where panel data is available from baseline and endline survey data are indicated with an asterisk $\left(^{*}\right)$. Our estimation strategy and approach to (multiple) hypothesis testing is discussed in Section 4.

\subsection{Family A: Access to communications}

\section{Hypothesis 1: Increased access to communications}

- Can you make a phone call from this dwelling?

(question: B6;variable: call_from_dwelling; $\beta>0$ )

- How many cell phones does your household own? (question: B8; variable: cellphonesowned; $\beta>0$ )*

- How many SIM cards does your household own? (question: B13; variable: numbersimcards; $\beta>0$ )*

\subsection{Family B: Social networks and communication}

\section{Hypothesis 2: Increased social connectedness - local}

- How many different people, within the barangay, do you speak to on a regular basis? (question: L1; variable: total_contacts_bgy; $\beta=0$ )*

- In the past 12 months, how often have you communicated with [bgy_nickname]? (questions: L12, L13, L14; variables: bgy_comm_inperson, bgy_comm_phone, bgy_comm_socialmedia; $\beta=0$; create dummy variable for "Daily" or "Weekly" response to any of these three variables)*

- Eigenvector centrality (question: L12; variables: eigenvector_c as calculated using within-site edges, bgy_comm_inperson, from the social network module; $\beta>0$; will calculate following Jackson (2010))*

\section{Hypothesis 3: Increased social connectedness — long distance}

- How many different people, outside the barangay, do you speak to or see at least once a year? (question: L2; variable: total_contacts_nonbgy; $\beta=0$ )* 
- In the past 12 months, how often have you communicated with [nonbgy_nickname]? (questions: L33, L34, L37; variables: nonbgy_comm_inperson,nonbgy_comm_phone, nonbgy_comm_socialmedia; $\beta=0$; create dummy variable for "Daily" or "Weekly" response to any of these three variables)*

- Count of people outside barangay talked to about NEWS, POLITICS, WEATHER, JOBS, or FINANCIAL MATTERS

(questions: L47, L48, L49, L53, L54; variables: contact_talknews, contact_talkpolitics, contact_talkweather, contact_talkjobs, contact_talkfinances; $\beta>0$; code as the total number of contacts)*

- When [hhmbr_fullname] ([hhmbr_nickname]) is away from the barangay, how frequently do they communicate with members of the household here in the barangay? (question: A38; variable: hhmbr_away_comm; $\beta>0$; create dummy variable for "Daily" or "Weekly" responses)

- On a scale of 1 (very isolated) to 5 (in very close contact), how connected do you feel to your friends and family who live outside of the barangay?

(question: F5, variable: feels_connected; $\beta>0$ )*

- Social network diversity (questions: L12, L13, L14, L33, L34, L37; variables: all social network module variables; $\beta>0$; calculate as geographic entropy of the network following Eagle, Macy, and Claxton (2010).)*

\subsection{Family C: Informedness}

\section{Hypothesis 4: Increased informedness}

- Knowledge of current events (questions: H1, H2, H3, H4, H5, H6, H7, H8, H9, H10; variables: know_q_prez, know_q_gov, know_q_tax, know_q_typhoon, know_q_pubhealth, know_q_inflation, know_q_wage_manila, know_q_wage_aurora, know_q_universe, know_q_bball; $\beta>0$; create count of the number of questions answered correctly.)

- People learn what is going on in the Philippines and the world from various sources. For each of the following sources, please indicate whether you use it to obtain information (1) daily, (2) weekly, (3) monthly, (4) less than monthly, or (5) never: Daily newspaper or printed magazines, TV news, Radio news, Mobile phone, Email, Facebook, Twitter, or other social media, Talk with friends and colleagues (questions: I1i, I1ii, I1iii, I1iv, I1v, I1vi, I1vii; variables: learn_newspaper, learn_tv, learn_radio, learn_mobile, learn_email, learn_socialmedia, learn_talk; $\beta>0$; create a count of the total number of sources for which the respondent selects "Daily" or "Weekly" response.)

- Did you know the price at the market before you sold it there?

(questions: K20, K33; variables: fish_last_knowprice, agric_last_knowprice; $\beta>$ 0 ; average across all fish or crops for which respondent answered; only include in sample those respondents about fish and crop prices from those who report fishing or farming as their primary occupation, respectively.) 


\section{Hypothesis 5: Increased disaster preparedness}

- How prepared do you feel your community is if a natural disaster were to hit your barangay? (question: E1; variable: disasterprepcomm; $\beta=0$; create dummy for "Very prepared" or "Prepared responses")

- If a typhoon were approaching this region, how much advanced warning do you expect you would have? (question: E2; variable: disasterwarning; $\beta>0$; create dummy for "Minutes" or "Hours" response)

- If evacuation were necessary, do you think you would be able to evacuate in time? (question: E3; variable: disasterevactime; $\beta>0$ )

\subsection{Family D: Economic outcomes}

\section{Hypothesis 6: Increased market access}

- Do you feel that you receive a fair price for the [crop_name or fish_name]? (questions: K22, K35; variables: fish_last_fairprice, agric_last_fairprice; $\beta>$ 0 ; create dummy variable for "more than fair" or "very fair" responses; average across all fish and crops for which respondent answered)

- Of the people that you mentioned, which people do you talk to about the PRICES of fish, rice, coconut, and/or bananas in nearby sitios?

(question: L52; variable: contact_talkcroppricefreq; $\beta=0$; code as the total number of contacts)*

- Of the people that you mentioned, from which people do you BUY GOODS?

(question: L57; variable: contact_buygoods; $\beta=0$; code as the total number of contacts)*

- Of the people that you mentioned, to which people do you SELL GOODS?

(question: L58; variable: contact_sellgoods; $\beta=0$; code as the total number of contacts)*

\section{Hypothesis 7: Changed migration}

- During the last 12 months, approximately how many separate times did [hhmbr_fullname] ([hhmbr_nickname]) leave the barangay for more than one week?

(question: A23; variable: hhmbr_away_times ${ }^{5} ; \beta=0$ )

- During the last 12 months (52 weeks), how many complete weeks did [hhmbr_fullname] ([hhmbr_nickname]) spend away from this dwelling?

(question: A24; variable: hhmbr_away_weeks; $\beta=0$ )

\footnotetext{
${ }^{5}$ Note for all household roster questions, we also asked identical questions of new household members (since baseline) under different varibale names (i.e. new_hhmbr_away_times). When cleaning data we will merge these into one set of variables and consider all respondents.
} 
- Household member away for work

(questions: A27, A28, A29, A30, A31; variables: hhmbr_away_weeks_const, hhmbr_away_weeks_agric, hhmbr_away_weeks_fish, hhmbr_away_weeks_otherwork, hhmbr_away_jobsearch; $\beta=0$; create dummy for any of these variables being equal to one)

- Does [hhmbr_fullname] ([hhmbr_nickname]) plan to travel outside of the barangay for any reason in the next 12 months? (question: A43; variable: hhmbr_plantotravel; $\beta=0$; create dummy if "Yes, definitely" or "Uncertain, but probably" responses)*

- Location of work (or school) (question: A41; variable: hhmbr_worklocation; $\beta=0$; create dummy variable if response $\neq$ "In the same sitio/barangay")*

\section{Hypothesis 8: Changed remittances and risk sharing}

- In the past 12 months (since May 2018), did you or a member of your household receive any remittance or gift of cash from friends or family member? (question: D7; variable: remitreceiveyesno; $\beta=0$ )*

- In the past 12 months (since May 2018), did you or a member of your household provide any remittance or gift of cash to friends or family members not living in the household? (question: D9; variable: remitgiveyesno; $\beta=0$ )

- In the past 12 months, have you received loans from any of the sources you mentioned? (question: D13; variable: loan_receive; $\beta=0$ )*

- In the past 12 months, have you sent loans to any of the people you mentioned? (question: D16; variable: loan_send; $\beta=0$ )

- During the weeks that [hhmbr_fullname] ([hhmbr_nickname]) was away from the barangay over the past 12 months, how much did /hhmbr_fullname] ([hhmbr_nickname]) send in remittances to members of the household?

(question: A34; variable: hhmbr_away_remit_amount; $\beta=0$ )

\section{Hypothesis 9: Changed income and expenditure}

- In the past 12 months, what was the estimated income your household received from [incomesource_namel?

(questions: D2, D4, D6; variable: total_income; $\beta=0$; create by summing incomeamount1, incomeamount2, and incomeamount3 variables)

- The last time [hhmbr_fullname] ([hhmbr_nickname]) was away from the barangay over the past 12 months, how much did he/she earn in total wages, benefits, self-employment profits, or other income sources? (questions: A32, A33; variable: hhmbr_away_income; $\beta=0)$

- Over the past 30 days, how much total income did /hhmbr_fullnamel ([hhmbr_nickname]) earn in wages, benefits, self-employment profits, or other income sources? (question: A42; variable: hhmbr_30day_income; $\beta=0$ ) 
- About how much did your household spend on /category/ in the past 7 days? (questions: C1i, C1ii, C1iii, C1iv, C1v, C1vi, C1vii, C1vii; variable: total_expend; $\beta=0$; create by summing across expend_food, expend_school, expend_business, expend_health, expend_energy, expend_clothing, expend_transport, expend_communication)

- Concerning your family's food consumption over the past one month, which of the following is true? (question: C2; variable: food_availability; $\beta=0$; create dummy variable for "Just adequate" or "More than adequate" responses)

\section{Hypothesis 10: Changed subjective well-being}

- Do you see yourself as part of your local community?

(question: I2; variable: agreepartof community; $\beta=0$; create dummy variable for "Definitely" and "Perhaps" responses)*

- Do you feel isolated from the rest of your country?

(question: I3 ; variable: agreeisolated; $\beta=0$; create dummy variable for "Perhaps not" or "Definitely not" responses)*

- All things considered, how satisfied are you with your life as a whole these days? Using this card on which 1 means you are "completely dissatisfied" and 10 means you are "completely satisfied" where would you put your satisfaction with your life as a whole? (question: F1;variable: life_satisfaction; $\beta=0$ )

- Comparing your quality of life these days to how it was 12 months ago, would you say that your quality of life is better now, the same as before, or worse now?

(question: F2; variable: life_quality_12mo; $\beta=0$; create dummy for "Better now" response)

- Comparing your quality of life these days to how it was 5 years ago, would you say that your quality of life is better now, the same as before, or worse now?

(question: F3; variable: life_quality_5yr; $\beta=0$; create dummy variable for "Better now" response)

- How satisfied are you with the financial situation of your household?

(question: F4; variable: $\mathrm{fin}_{\text {_satisfaction; } \beta=0 \text { ) }}$

\subsection{Important control variables}

Where available (outcomes with '*'s above), baseline outcome measures will be used as control variables when testing for treatment effects on endline measures using an ANCOVA specification. For outcome indices (described below), we will not control for baseline indices but rather each component of the baseline index separately (to allow for the possibility that some variables were not collected at baseline). For households administered baseline surveys in treatment sites during site launches, we will verify that they are no different on average from original baseline respondents through balance checks like those described in Section 4.1 
below. If the joint F-test finds significant differences between these groups, we will only use original baseline households in our sample. If the joint F-test does not find significant differences between these groups, we will use all households in our sample.

In addition, we view several variables as important potential controls to increase precision, which we will now list. All treatment effect estimates will be shown with and without these controls, where we will employ machine-learning techniques to choose a precision-maximizing control set from amongst these controls for each regression. This is consistent with the recommendation of Ludwig, Mullainathan, and Spiess (2019). We will control at the level of the same respondent as each outcome if possible (i.e. if we are considering a migration outcome that is asked of every adult household member, we will control for the gender of that same household member), though some controls are only measured at the household or primary adult respondent level. These latter controls will still be considered in all regressions as they may affect responses. Finally, in the case of controls for regressions with householdlevel outcomes in which controls are recorded for multiple adults, we will use the household average.

Candidate control variables:

- Respondent gender (Available for all household members)

- Respondent age (Available for all household members)

- Respondent education (Available for all household members)

- Household asset index (This will be calculated by taking the first principal component of those assets in the HH survey asset module from baseline)

- Respondent cognitive ability (Only available for primary adult respondents)

- Household size (Household-level)

- Number of cell phones owned by HH (Household-level)

- Number of sim cards owned by HH (Household-level)

- Household's primary income source (Create dummies for each category)

\section{Empirical Analysis}

\subsection{Balance Checks}

We will conduct two sets of baseline balance tests: (i) balance on all variables used for randomization stratification, and (ii) balance on other important covariates, which includes all baseline measures of outcomes and important controls that are available. For each group of covariates, a standard balance table will be reported, including the mean for the treatment condition, difference relative to the control condition, and t-tests of the null hypothesis of zero difference. The table for variables used in stratification is merely a check on whether stratification were conducted properly, so it will appear in the appendix. The table for other 
variables is potentially more interesting and will appear in the body of the paper. Should any of the t-tests for a covariate in this table reveal imbalance, that covariate will be used as a potential control in all regression analyses (see above for discussion of how we will select controls).

In addition, we will regress treatment on all variables in (i) and (ii) simultaneously and report the F-statistic for joint significance.

We will conduct two analogous balance tests for our promotion treatment assignment, except for the fact that we will check balance between all possible groups - each of the five treatment groups and the control group. For these treatments, we will also regress each separate treatment indicator on all covariates simultaneously and report the F-statistic for joint significance.

\section{$4.2 \quad$ Primary Outcome Treatment Effects}

Define $Y_{i}$ as one of the above outcomes measured at endline for individual $i$ living in household $h$ in village $v$ and $Y_{i}^{b}$ as the baseline value of the outcome, if available. ${ }^{6}$

We denote village-level treatment (installation of a cell tower) by $T_{v}$, and village level exposure (in months, prior to endline), by $E_{v}$. Stratum (i.e. matched pair) dummies are indicated by $\nu_{s}$.

\subsubsection{Village-level intent to treat}

We will estimate two village-level ITT specifications:

$$
Y_{i}=\beta^{I T T} T_{v}+\rho Y_{i}^{b}+\nu_{s}+\epsilon_{i}
$$

and

$$
Y_{i}=\beta^{I T T E} E_{v}+\rho Y_{i}^{b}+\nu_{s}+\epsilon_{i}
$$

Standard errors and p-values for this and all specifications are discussed below (Section 4.4).

\subsubsection{Household-level treatment-on-the-treated by cellular network access and mobile phone useage}

We want the krigged signal strength to be our variable of interest, $r_{i}$, the first stage is to regress $r_{i}$ on $T_{v}$ (and other controls, $Y_{i}^{b}, X_{i}$ ). Then use the fitted values, $\widehat{r}_{i}$, in the second stage, rather than $T_{v}$.

$$
\begin{aligned}
& r_{i}=\eta * T_{v}+X_{i} \gamma_{i}+\zeta Y_{i}^{b}+\mu_{s}+\psi_{i} \\
& Y_{i}=\beta^{\text {TOTSIGNAL }} \widehat{r}_{i}+X_{i} \alpha_{i}+\rho Y_{i}^{b}+\nu_{s}+\epsilon_{i}
\end{aligned}
$$

\footnotetext{
${ }^{6}$ In the case that $Y_{i}$ is a hypothesis index, $Y_{i}^{b}$ will be a vector of available baseline values of each of the variables that make up the index. Also, if $i$ was not interviewed at baseline, and if $Y_{i}$ is a household-level outcome, we replace $Y_{i}^{b}$ with $Y_{h}^{b}$.
} 
In this specification, we will use a two-staged least squares approach to measuring household-level treatment effects. In our first stage, Equation 3, we will instrument for network signal, instrument for the krigged signal strength, our variable of interest, $r_{i}$, using treatment assignment, $T_{v} \cdot{ }^{7}$ In our second stage, Equation 4, we will use the fitted values, $\widehat{r}_{i}$, from the first stage regression, rather than $T_{v}$ in our estimates of the treatment effect.

In treated villages, we directly observe phone use from the Call Detail Records. We therefore estimate a version of Equation 4 on the sample of households in the treated villages, in which we exploit household-level variation in mobile phone usage, $P_{i}$, induced by random assignment of price discounts $D_{i}$. We instrument for $P_{i}$ with $D_{i}$ in addition to $T_{v}$ :

$$
Y_{i}=\beta^{T O T P} \hat{P}_{i}+\rho Y_{i}^{b}+\nu_{s}+\epsilon_{i}
$$

\subsection{Primary Outcome Heterogeneous Treatment Effects}

We will test for heterogeneous effects on our primary outcomes in two ways.

First, following standard regression-based approaches, we will look for differential (linear) effects of treatment on outcomes by subgroup. For a subgroup defined by $X_{i}, X_{h}$, or $X_{v}$, we will test for heterogeneous effects by interacting our treatment variables with the heterogeneity variable. For instance, the heterogeneous version of specification (1) would estimate:

$$
Y_{i}=\beta_{1} T_{v}+\beta_{2} X_{i}+\beta^{H I T T} T_{v} * X_{i}+\rho Y_{i}^{b}+\nu_{s}+\epsilon_{i}
$$

where $\beta^{H I T T}$ is a test for heterogeneity. In this "standard" approach, we will test for heterogeneity along all of the characteristics listed as important control variables in Section 3.5.

Second, we will use machine learning approaches that use cross-validation to discover primary axes of heterogeneity. We will do this by applying two related techniques: (i) the sorted effects method of Chernozhukov et al. (2018), which calculates a collection of estimated partial effects sorted in increasing order and indexed by percentiles; and (ii) the tree-based approaches of Wager and Athey (2018) and Athey and Imbens (2016), which provide non-linear approaches for estimating heterogeneity in causal effects in experimental and observational studies and for conducting hypothesis tests about the magnitude of differences in treatment effects across subsets of the population. With these methods, we intend to provide the full set of $X_{i}, X_{h}$, and $X_{v}$ collected in our baseline survey, to allow the unsupervised algorithms to discover the primary directions of heterogeneous effects in our data.

\subsection{Estimating p-values}

Equations (1), (2), and (4) rely on village-level variation. As we only have 14 villages in our sample, we do not expect standard errors that rely on asymptotic assumptions to be correct. For all hypothesis tests using these specifications, instead, we will use the wild bootstrap cluster-t procedure using 1000 simulations (Brooks and Donovan, 2017; Cameron, Gelbach, and Miller, 2008). As a robustness check, we will also report p-values derived from

\footnotetext{
${ }^{7}$ In this case we mean access to any cellular signal for the VBTS network or other major carrier. Mobile network signal measurement is described above in Section 2.5.
} 
randomization inference for robustness (we will draw all 1000 possible counterfactual treatment assignments, estimate treatment effects in each case, and determine what percentage of counterfactual treatment effect coefficients lie above the observed treatment effect coefficient to obtain a p-value) (Fisher, 1960).

For specifications relying on household-level randomization (i.e. random price promotions), we will estimate standard errors clustered at the household level and we will report p-values derived from randomization inference as a robustness check.

\subsection{Multiple hypothesis test corrections}

To address multiple hypothesis testing within each hypothesis, for each hypothesis we will create an outcome index that is the z-score average of each of the outcomes associated with the hypothesis, following Kling, Liebman, and Katz (2007). This index will serve as our "primary" outcome for each hypothesis. We will then correct for multiple hypothesis testing across all of the hypothesis indices within each family by controlling for the False Discovery Rate following Anderson (2008).

We will also create an index for each family by averaging across outcome indices for all of the hypotheses in a family. These indices will serve as our "primary" outcome for each family. We will not create an index across families nor will we correct for multiple hypothesis testing across families as we view each family as a distinct step in our theory of change.

We will use an analogous procedure to correct for multiple hypothesis testing within each dimension by which we measure heterogeneity, but not across dimensions of heterogeneity nor between our primary hypothesis tests and our tests for heterogeneity.

\subsection{Unit of analyses}

Some of our outcome variables are measured at the household level, some at the adult respondent level, ${ }^{8}$ and some at the household roster level. ${ }^{9}$ We will always conduct analysis at the most disaggregated level possible. In the case of creating indices when outcomes are at different levels, we will aggregate to the most disaggregated level possible by taking means (i.e. if three outcomes are at the household level and one at the adult respondent level for a hypothesis, we will average across two adult respondents' response first to make all outcomes at the household level and then will form the index).

\subsection{Sample attrition}

First, attrition rates will be reported for households in treatment and control villages as well as for households in each of the promotion treatment or control arms. The difference between these rates will not be formally tested, as rejecting the null hypothesis of zero difference does not necessarily imply bias in our estimators. Second, attritors and non-attritors will be compared on observables following an analogous procedure as for experimental balance, outlined above: we will regress a dummy for attriting on all variables in (i) and (ii)

\footnotetext{
${ }^{8}$ At baseline, $41.7 \%$ of households had 2 adult respondents, $58.3 \%$ had two respondents.

${ }^{9}$ The mean number of adults in a household at baseline was $2.78($ mean $=2$, mode $=2, \max =12)$
} 
simultaneously and report the F-statistic for joint significance, where (i) are all variables used for randomization stratification and (ii) are other important covariates, which includes all baseline measures of outcomes and important controls that are available.

Lee bounds for estimated effects on primary outcomes will appear in the appendix if the F-statistic for joint significance is significant.

\section{Testing Social Networks as a Mechanism}

Our theory of change posits that the social and economic impacts of access to cellular networks will be mediated by expansion in social network structure, where such expansion is enabled by the phone network.

To test this specific mechanism, we will conduct analogous hypotheses tests to those for hypotheses $4-10^{10}$ except, rather than testing the hypothesis that cellular access leads to increased informedness, we will test the hypothesis that social network expansion - as driven by cellular access - leads to increased informedness, etc.

Empirically, we will consider a special case of Equation (1), where $S_{i}$ indicates the social connectedness of $i$ :

$$
Y_{i}=\beta^{N E T} S_{i}+\rho Y_{i}^{b}+\nu_{s}+\epsilon_{i}
$$

and $S_{i}$ is instrumented with $T_{v}$. Likewise, we test an analogous versions of specification (2) that instruments for $S_{i}$ with $E_{v}$. We will also estimate analogous versions of both TOT specifications - Equations 4 and 5 - which replace $C \hat{N}_{i}$ and $\hat{P}_{i}$ with $S_{i}$ (and $S_{i}$ is instrumented by $C \hat{N}_{i}$ and $\hat{P}_{i}$, respectively).

We will construct $S_{i}$ in two ways: as local social connectedness (an index of outcomes of hypothesis 2 in Section 3) and as long distance social connectedness (an index of outcomes of hypothesis 3). If these two measures of social connectedness are found not to be correlated with each other, we will test for the impacts of local and long distance social connectedness separately. If these two measures are found to be strongly correlated with each other, we will test for their impacts jointly.

In these specifications, we are particularly concerned with a violation of the exclusion restriction - that treatment could directly impact outcomes (not only through social networks). We will include household income and time use as additional potential controls in an attempt to control for all of the direct effects of treatment.

Note we will treat these additional hypotheses about the mechanism as distinct from and in parallel to our main hypotheses about impacts for the purposes of multiple hypothesis test corrections, as we do with all tests for heterogeneous impacts, i.e. we will correct for multiple hypothesis testing within our mechanism hypothesis tests by family, but not across these tests and the tests for our main impacts.

\footnotetext{
${ }^{10}$ Hypothesis 1 , we believe, is a pre-cursor to changes in social networks so will not consider it as being impacted by social network expansion. Hypotheses 2 and 3 are tests of social network expansion itself.
} 


\section{Demand for Community Cellular Access}

Demand for community cellular access is an important policy outcome that we are well-suited to measure using our random CCN price variation. More specifically, we will estimate and report the price elasticity of cellular network usage in our treatment sites. Let $U_{i t}$ be the usage, in terms of pesos of expenditure, of individual $i$ during week $t$. Let Price ${ }_{i t}$ be a vector of prices that individual $i$ faces during week $t$. Given the fact that we will have many zeros in usage, we will use an inverse hyperbolic sine transformation to estimate a price elasticity, following Bellemare and Wichman (2019). We will first estimate the equation:

$$
\operatorname{arcsinh}\left(U_{i t}\right)=\beta^{D E M A N D} \operatorname{Price}_{i t}+\nu_{s}+\gamma_{h}+\gamma_{w o f m}+\gamma_{m}+\epsilon_{i t}
$$

where arcsinh is the inverse hyperbolic sine transformation. To improve precision, $\nu_{s}$ are stratification fixed effects as above, $\gamma_{h}$ are household fixed effects, $\gamma_{w o f m}$ are week and week of the month fixed effects, and $\gamma_{m}$ are month fixed effects. We will not consider in our sample individuals that never purchased a SIM card nor those that purchased a SIM card but never purchased any load.We will then directly estimate the elasticity of demand following Bellemare and Wichman (2019) equation (7):

$$
\hat{\xi}_{y x}=\hat{\beta} x \frac{\sqrt{y^{2}+1}}{y}
$$

We will use $\beta^{D E M A N D}$ for $\hat{\beta}$ and mean values of $y$ and $x$ for our elasticity estimation.

As a secondary specification, we will conduct the same regression as above but with price as the dependent variable and will directly report $\beta^{D E M A N D}$ as an elasticity. According to Clemens and Tiongson (2017), regression coefficients on variables transformed with the inverse hyperbolic sine can be interpreted identically to those using the traditional log transformation (as approximating percent changes) for any peso quantity encountered in practice.

As a robustness check, we will also estimate using a log-log specification, throwing out zero usage observations.

There are two ways we can calculate $U_{i t}$-we can include only costs born by the CCN household, or we can include both costs born by the CCN household for calls and texts and those born by those calling the CCN household (calls are paid for by those placing the call). As both of these measures are policy relevant (the latter, for example, may be what mobile network operators care more about if lower prices spurs more incoming calls and those calls are paying higher rates on the same network), we will report results on both separately. Note in both cases we will also calculate usage using pre-promotion prices, not post-promotion prices, to make treatment and control group usage comparable.

Note we do not consider the test that the price elasticity is not equal to zero as a primary research hypothesis and will not include our estimate of demand in multiple hypothesis test corrections. 


\section{Secondary Hypotheses and Analyses}

We have several secondary hypotheses that we plan to address in separate academic papers from the one described up to this point. This is because (i) we view these outcomes as distinct from the primary outcomes, and (ii) each of these secondary outcomes can speak to separate, policy relevant research questions.

We have two secondary families. The first is political economy, which has hypotheses:

1. Increased political participation

2. Increased political manipulation

3. Increased political economic knowledge

The second is intra-household decision-making, which has hypotheses:

4. Increased role of women in income decisions

5. Increased role of women in fishing/agriculture decisions

6. Increased role of women in control of resources

7. Decreased spousal difference in reported fish/crop prices

As with our primary survey outcomes, each hypothesis has several specific outcomes on which we will measure causal impacts, which we will now outline. For each outcome, we write out the exact question from our endline survey, attached. In parenthesis, we also include the variable name in the survey for easy reference, and we include either $\beta>0, \beta<0$, or $\beta=0$ to designate whether our priors suggest a one-sided or two-sided hypothesis test for the outcome. Finally, we include any additional information about how survey responses will be coded if such is unclear from the question.

\subsection{Secondary Family A: Political economy}

\section{Secondary Hypothesis 1: Increased political participation}

- Did you vote in the 2019 election? (question: M2; variable: vote2019; $\beta=0$ )*11

- In the last 6 months, how many times did you talk to the barangay captain? (question: M1; variable: freqspeakbgycap_6m; $\beta=0$; create dummy variable for "Often" or "Sometimes" responses)

\section{Secondary Hypothesis 2: Increased political manipulation}

- Did someone offer you money (or something of value) for your vote? (question: M3; variable: vote_buy; $\beta=0$ )

- Which of the these people know how you voted? (question: M4; variable: brgy_knowsvote; $\beta=0$; create $0-5$ count of the number of people that were selected)

\footnotetext{
${ }^{11}$ Baseline question: Did you vote in the 2016 election?
} 


\subsection{Secondary Family B: Intra-household decision-making}

\section{Secondary Hypothesis 4: Increased role of women in income decisions}

- In your household, who decides what to buy in the market or what to cook for the family? (question: J1; variable: decidemarket; $\beta=0$; create dummy if a woman decides)

- In your household, who decides when buying expensive things for the household such as radio, $T V$, etc.? (question: J2; variable: decideexpensive; $\beta=0$; create dummy if a woman decides)

- In your household, who decides how to manage the household budget? (question: J3; variable: decidesavings; $\beta=0$; create dummy if a woman decides)

- How much input did you have in decisions on the use of income generated from fishing? (question: K14; variable: fishing_decisions_income; $\beta=0$; limit to sample of woman respondents and create dummy for "Input into some decisions" or "Input into most or all decisions" responses)

- How much input did you have in making decisions about farming? (question: K25; variable: agric_decisions_income; $\beta=0$; limit to sample of woman respondents and create dummy for "Input into some decisions" or "Input into most or all decisions" response)

\section{Secondary Hypothesis 5: Increased role of women in fishing/agriculture decisions} 12

- Did you yourself participate in fishing in the past 12 months?

(question: K10; variable: fishing_participate; $\beta=0$; limit to sample of women respondents)

- When decisions are made regarding fishing, who is it that normally makes the decision? (question: K11; variable: fishing_decisions_who; $\beta=0$; create dummy if a woman decides)

- How much input did you have in making decisions about fishing?

(question: K12; variable: fishing_decisions_input; $\beta=0$; limit to sample of woman respondents and create dummy for "Input into some decisions" or "Input into most or all decisions" responses)

- To what extent do you feel you can make decisions regarding fishing if you wanted to? (question: K13; variable: fishing_decisions_ability; $\beta=0$; limit to sample of woman respondents and create dummy for "Medium extent" or "To a large extent" responses)

\footnotetext{
${ }^{12}$ Note for the index of outcomes for this hypothesis, instead of following the same z-score average as with other indices, the above variables will be coded into an index following the Abbreviated Women's Empowerment in Agriculture Index available at https://weai.ifpri.info/weai-resource-center/guides-and-instruments/
} 
- Which household members conducted the sale of [fish_name]?

(question: K16; variable: $\mathbf{f i s h} \_$last_who; $\beta=0$; create dummy if a woman conducted sale and average over different fish type)

- Did you yourself participate in farming in the past 12 months?

(question: K23; variable: agric_participate; $\beta=0$; limit to sample of women respondents)

- When decisions are made regarding farming, who is it that normally makes the decision?

(question: K24; variable: agric_decisions_who; $\beta=0$; create dummy if a woman decides)

- How much input did you have in making decisions about farming?

(question: K25; variable: agric_decisions_input; $\beta=0$; limit to sample of woman respondents and create dummy for "Input into some decisions" or "Input into most or all decisions" response)

- To what extent do you feel you can make decisions regarding farming if you wanted to? (question: K26; variable: agric_decisions_ability; $\beta=0$; limit to sample of woman respondents and create dummy for "Medium extent" or "To a large extent" response)

- Which household members conducted the sale of [crop_name]?

(question: K29; variable: agric_last_who; $\beta=0$; create dummy if a woman conducted sale and average over different crop types)

\section{Secondary Hypothesis 6: Increased role of women in control of resources}

- Who in your household has a bank account, either alone or jointly?

(question: D18; variable: bankaccountwho; $\beta>0$; create dummy for a woman having a bank account, either alone or jointly)

- Who in your household owns a cell phone? (question: B12; variable: cellphoneswho; $\beta>0$; use as outcome proportion of simowning adults in $\mathrm{HH}$ who are women)

- Who in your household owns a SIM card?

(question: B15; variable: simcardwho; $\beta>0$; use as outcome proportion of sim-owning adults in $\mathrm{HH}$ who are women)

\section{Secondary Hypothesis 7: Decreased spousal difference in reported fish/crop prices}

- What was the price per kilogram that you received when you last sold the [fish_name]? (question: K21; variable: fish_last_price difference; $\beta<0$; create variable that is the difference between reported last price of fish between head of household and spouse of head of household adult respondents, averaged over fish breeds [note both respondents will be answering about the same sales]) 
- What was the price per kilogram that you received when you last sold the [crop_name]? (question: K34; variable: agric_last_price difference; $\beta<0$; create variable that is teh difference between reported last price of crops between head of household and spouse of head of household adult respondents, averaged over crops [note both respondents will be answering about the same sales]) 


\section{References}

Aker, Jenny C. (2010). "Information from Markets Near and Far: Mobile Phones and Agricultural Markets in Niger". American Economic Journal: Applied Economics 2(3): 4659.

Aker, Jenny C. and Joshua E Blumenstock (2015). "The Economic Impacts of New Technologies in Africa". In: The Oxford Handbook of Africa and Economics: Policies and Practices. Ed. by Célestin Monga and Justin Yifu Lin. Vol. 2. The Oxford Handbook of Africa and Economics. Oxford University Press.

Anderson, Michael L (2008). "Multiple Inference and Gender Differences in the Effects of Early Intervention: A Reevaluation of the Abecedarian, Perry Preschool, and Early Training Projects". Journal of the American statistical Association 103(484): 1481-1495.

Athey, Susan and Guido W. Imbens (2016). "Recursive Partitioning for Heterogeneous Causal Effects". Proceedings of the National Academy of Sciences 113(27): 7353-7360.

Barela, Mary Claire, Mae Sincere Blanco, Philip Martinez, Miguel Carlo Purisima, Kurtis Heimer, Matthew Podolsky, Eric Brewer, and Cedric Angelo Festin (2016). "Towards Building a Community Cellular Network in the Philippines: Initial Site Survey Observations". Proceedings of the Eighth International Conference on Information and Communication Technologies and Development. ICTD '16. New York, NY, USA: ACM, 55:155:4.

Beck, Cole, Bo Lu, and Robert A. Greevy (2016). nbpMatching: Functions for Optimal Non-Bipartite Matching. R Package Version 1.5. 1.

Bellemare, Marc F and Casey J Wichman (2019). "Elasticities and the Inverse Hyperbolic Sine Transformation": 26.

Blumenstock, Joshua E., Nathan Eagle, and Marcel Fafchamps (2016). "Airtime Transfers and Mobile Communications: Evidence in the Aftermath of Natural Disasters". Journal of Development Economics 120: 157-181.

Brooks, W. J. and Kevin Rjb Donovan (2017). "Eliminating Uncertainty in Market Access: The Impact of New Bridges in Rural Nicaragua".

Cameron, A Colin, Jonah B Gelbach, and Douglas L Miller (2008). "Bootstrap-Based Improvements for Inference with Clustered Errors". The Review of Economics and Statistics 90(3): 414-427.

Chernozhukov, Victor, Mert Demirer, Esther Duflo, and Iván Fernández-Val (2018). Generic Machine Learning Inference on Heterogenous Treatment Effects in Randomized Experiments. Working Paper 24678. National Bureau of Economic Research.

Clemens, Michael A and Erwin R Tiongson (2017). "Split Decisions: Household Finance When a Policy Discontinuity Allocates Overseas Work". Review of Economics and Statistics 99(3): 531-543.

Cressie, Noel (1990). "The Origins of Kriging". Mathematical Geology 22(3): 239-252.

Eagle, Nathan, Michael Macy, and Rob Claxton (2010). "Network Diversity and Economic Development". Science 328(5981): 1029-1031.

Fisher, Ronald Aylmer et al. (1960). "The Design of Experiments." The design of experiments. (7th Ed 1960).

Greevy, Robert A., Carlos G. Grijalva, Christianne L. Roumie, Cole Beck, Adriana M. Hung, Harvey J. Murff, Xulei Liu, and Marie R. Griffin (2012). "Reweighted Mahalanobis Dis- 
tance Matching for Cluster-Randomized Trials with Missing Data". Pharmacoepidemiology and Drug Safety 21(S2): 148-154.

GSMA (2018). The Mobile Economy: Asia Pacific 2018. GSMA Intelligence.

GSMA (2019). The Mobile Economy 2019. GSMA Intelligence.

Heimerl, Kurtis and Eric Brewer (2010). "The Village Base Station". Proceedings of the 4th ACM Workshop on Networked Systems for Developing Regions. NSDR '10. San Francisco, CA: ACM, 14:1-14:2.

Jackson, Matthew O. (2010). Social and Economic Networks. Princeton University Press. $519 \mathrm{pp}$.

Jensen, Robert (2007). "The Digital Provide: Information (Technology), Market Performance, and Welfare in the South Indian Fisheries Sector". The Quarterly Journal of Economics 122(3): 879-924.

Kling, Jeffrey R, Jeffrey B Liebman, and Lawrence F Katz (2007). "Experimental Analysis of Neighborhood Effects". Econometrica 75(1): 83-119.

Labonne, Julien and Robert S. Chase (2009). "The Power of Information: The Impact of Mobile Phones on Farmers' Welfare in the Philippines". World Bank Policy Research Working Paper No. 4996.

Ludwig, Jens, Sendhil Mullainathan, and Jann Spiess (2019). "Augmenting Pre-Analysis Plans with Machine Learning". AEA Papers and Proceedings 109: 71-76.

Muto, Megumi and Takashi Yamano (2009). "The Impact of Mobile Phone Coverage Expansion on Market Participation: Panel Data Evidence from Uganda". World Development 37(12): 1887-1896.

Rogerson, Peter A., Eric Delmelle, Rajan Batta, Mohan Akella, Alan Blatt, and Glenn Wilson (2004). "Optimal Sampling Design for Variables with Varying Spatial Importance". Geographical Analysis 36(2): 177-194.

Suri, Tavneet and William Jack (2016). "The Long-Run Poverty and Gender Impacts of Mobile Money". Science 354(6317): 1288-1292.

Wager, Stefan and Susan Athey (2018). "Estimation and Inference of Heterogeneous Treatment Effects Using Random Forests". Journal of the American Statistical Association 113(523): $1228-1242$. 


\section{Appendix}

\subsection{VBTS Konekt Network}

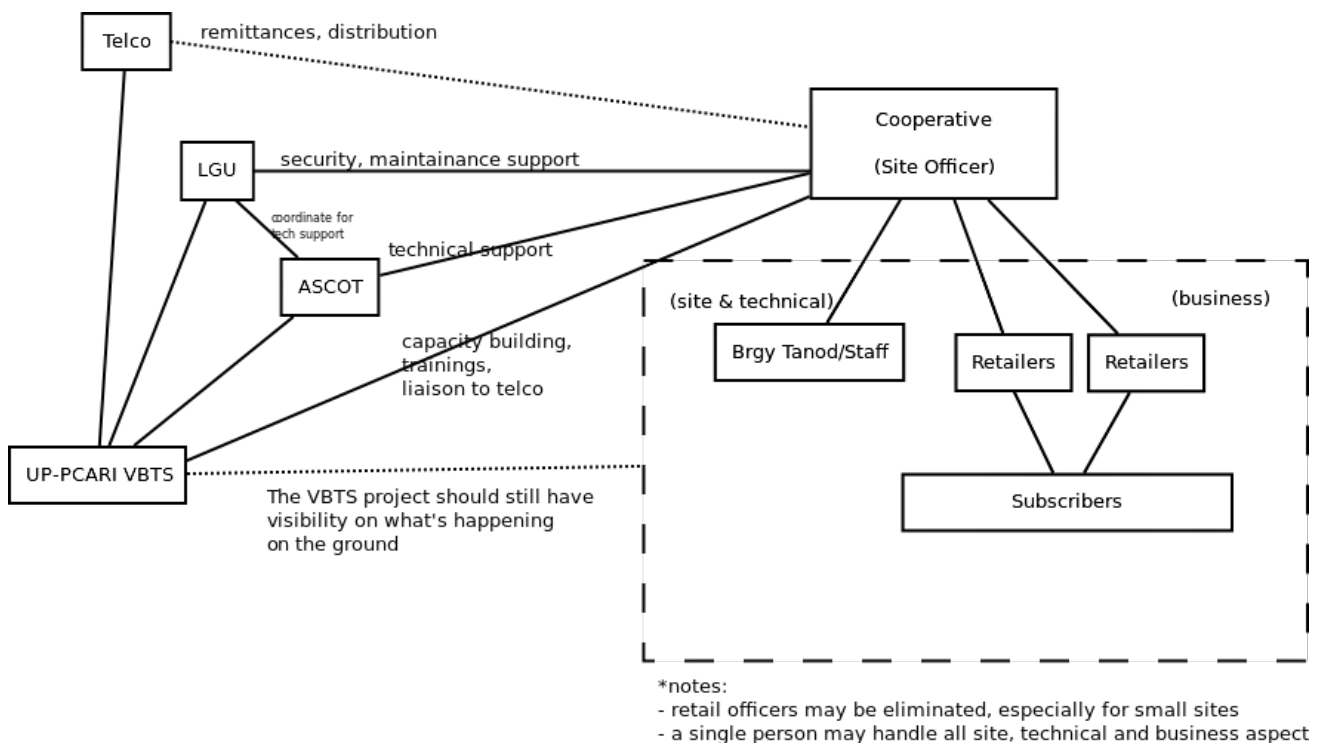

Figure 2: VBTS Konekt Organizational Structure 


\subsubsection{Site Launch Manual}

This document serves as an instruction manual for the registration of SIM cards for the Village Base Station cell tower project. Members of the cooperative recruited for the registration should use this document as a step-by-step guide for the registration process. It is critical that all steps are followed as outlined in this manual. As such it is important that you read this document in its entirety and become familiar with all of the stages of SIM card registration. All team members are expected to know their own responsibilities as well as expectations for other team members. Each section of this manual includes a table with tasks covered at each stage of the registrations process. You will also find a guide for who is responsible and accountable for each task as well as who needs to be consulted or informed prior to and after a task is completed. Make sure that you know what is assigned to you and who you should consult or inform.

\section{Team Composition}

Our team consists of members with specific roles and responsibilities. In order to carry out an effective SIM registration process, it is important that each member of the team know their role, understand who they should work with, and who to inform if questions arise.

- Barangay/Sitio Representatives - local leaders (tanods, barangay tribal leaders, etc.)

- Electronic Load (E-Load) Vendors - Nominated through cooperatives (sari sari vendors, check on capacities). Aside from selling e-load, will also handle follow-up registration.

- Registration Supervisor - IPA-hired staff member acting as supervisor to team of Registration Staff. Performs last check to ensure that the SIM is matched to the correct person on the database. Someone accountable and proficient in our processes.

- Registration Staff - Manage the SIM card registration, from matching of registrants to names in the baseline survey database, to giving out SIM cards. Conducts household survey for registrants who were not surveyed in initial baseline.

- UPD Registration Manager - Lead representative from UP who is familiar with the technical details as well as the registration details. Handles customer service questions/issues.

- Cooperative Representatives - Representatives of the multipurpose cooperatives tasked to oversee the cell phone tower's operations.

- IPA Project Manager - Responsible to overall research project management and monitoring of research protocols. 


\section{Pre-Registration: Local Authorization and Information Drive}

Approximately three days before the launch of the network, IPA enumerators will be assigned to a network site. All registration team members must attend a training prior to participating in the Pre-Registration process. The IPA Project Manager is responsible for ensuring that all team members are properly trained. During the pre-registration phase, there will be two principal activities: getting approval from the barangay officials and other local leaders to hold a public event for the official registration of SIM cards, and a public information drive to invite people to the event.

During this period, the community should be informed of the scheduled launch of the new cellular network. Prior to doing so, it is important to obtain local authorization and agreement on the date and time of the community registration event. With assistance from local officials such as kagawads, barangay tanods, sitio/purok, leaders, or tribal council members, establish a date, time and location for the community registration event. The local leaders should be asked to help identify Barangay Representatives to assist in spreading the word about the community registration event.

All relevant local officials need to be informed prior to beginning activities in the barangay. For most areas, this will require simply talking to the barangay council, represented by the barangay captain, kagawads, or other authorized officials. However, in some other areas, this may require getting permissions as well from tribal council officials (particularly for areas with a large presence of indigenous peoples or IPs) or even the local military contingent. The barangay officials can tell you which additional groups you will need to contact.

While obtaining permissions, inform the officials that you would like to arrange a meeting with the entire community in which you will be announcing the activation of a new cell phone network. By this time, the barangay officials should be aware of the installation of the network, so the event will be the official launch. The Cooperative Lead, with the support of the UPD Engineering Team, is responsible for ensuring that the officials understand the structure and scope of the VBTS cellular network.

The community meeting should be held in a public space, easily accessible for most of the community's residents. Tell them that at this meeting, you will be distributing SIM cards to the community's residents, up to one free SIM card per adult individual (15 years old and up). You will also be recording various identification details about the residents such as their name, surname, the name of their household head, as well as some additional demographic information. Tell them that the SIM card users' identification details will be kept confidential, but we will need to collect this data so as to ensure that we can limit one SIM card to each user and trace the usage to each person in order to carry out research and better improve the services provided to customers.

Once you have obtained permission, you can now go around the community informing the residents of the meeting. The Barangay Representatives should be expected to help the registration team in spreading word to all members of the community. We want to ensure high attendance at the community registration event. You should make sure that all residents are properly informed of the date, time, and location of the community event. In order to assist with the information drive, be sure to distribute brochures showing the date and location of community meeting. In addition, ask them to collect the names and phone numbers of seven contacts that they will likely contact the most frequently. These details 
will also be included in the registration.

Some of the target communities may have households located far from the center of town which could be overlooked (this is sometimes the case in areas with indigenous peoples that are culturally separate from the majority population; these households should be informed of the meeting as well).

Be sure that all households are informed of the community registration event at least several days in advance of the event.

\section{Community Registration}

The community registration event is a critical step in launching the community cellular network. We want to ensure that the community event has near-universal attendance from adults living in the Barangays and Sitios encompassed by a given network site. Note that you will remain in the barangay for about one week after launch to continue registering residents who were unable to attend the community registration event SIM cards (See Follow-up Registration).

\section{Step 1: Set-up registration booth}

Set up a publicly-accessible and central location within the barangay (such as the barangay hall, health center, etc.) for registration and distribution of SIM cards.

At least two tables need to be set up for the registration process, each to be manned by at least two Registration staffers. The different tables can handle separate and simultaneous registrations in order to speed up the process for registrants. Each staffer at each table will handle recording of names and other identification details of individuals. Leading up to each table, arrange chairs in a line so that registrants can rest while waiting for their turn to register and be given a SIM card. The tables can be separated according to the first letter of the last name of the registrant so that attendees can know where they should line up. Staffers can also transfer to different tables depending on the length of the line, with the decision to switch tables to be made by the supervisor. A separate line should also be created for special groups, such as senior citizens, the handicapped or disabled, etc.

Using the database entry software, individuals will be connected to a database with household data that was previously collected by IPA. After completion of the registration, the staffer will distribute the correct SIM card to the registrant and assist them with any questions regarding the registration. At the same time, they will be closely monitored by the Registration Supervisor.

The registration team should also purchase or prepare food for the attendees of the meeting in order to encourage attendance. You can ask the barangay leaders or other local officials for help in finding the best way to do this, whether by assigning a member of the community to prepare and serve the food for a fee or by providing the food yourself.

\section{Step 2: Community meeting}


Before the start of the meeting, the protocol often used for meetings organized by the barangay is to have people sign an attendance sheet upon entering the meeting hall. UPD will also likely have an attendance sheet. We should assist both in collecting the names of individuals who attend the meeting.

The welcoming remarks can be given by Barangay Representatives. The SIM card registration team should introduce themselves and announce the launch of the new cellular phone network. The Cooperative Representatives are responsible for explaining the community cellular network in a such a manner that all attendees of the community registration event can understand the scope and structure of the network rollout. Our research partners from UPD will also assist in explaining the technical aspects of the cellular network. It is important to stress that the network is part of a research project and is being rolled out for an experimental.

Most of the attendees will have likely heard of the construction of the cellular tower in advance. Inform the attendees that the meeting marks the official launch of the tower. The tower is not directly provided by Globe or Smart and therefore will require users to use a separate SIM card and phone number. Users of this SIM card, however, can make texts and calls to other networks as ordinary SIM cards do. This is also a good opportunity to explain the features of the network, such as the price of ordinary texts and calls, as well as its limitations. Emphasize that the tower is still being piloted and that they should not expect the same level of reliability of services as they get in cities.

Explain that in order to register to receive a SIM, they will need to line up and wait for their turn to be registered. Following verification, individuals will then receive a free SIM card and sign a waiver agreeing that this is an experimental service. A member of the registration team will also provide the customer with his/her unique phone number. A final step at the table will involve verifying the information and ensuring that the customer is knowledgeable of how to use the SIM card.

After all of this information has been shared, the meeting facilitators will open the floor to questions from the community. One member of the registration must be assigned to take notes of any comments or questions that members of the community have. If you are unsure of the answer to the question, inform the audience that the questions will be addressed at a later date.

Once all of their questions have been answered or noted and preparations for the registration have been finished, inform the community that the registration may begin. Refer them to the lines corresponding to the first letter of their last name, and.tell them that they will need to line up in the correct line. Members of the same household can register at the table together, though each will be given separate SIM cards. Food can be served during the registration process so that people can eat and socialize while waiting for their turn.

Lastly, inform the community that those who are unable to register on the day of the meeting can return within the next few days while the registration team is still in the community.

As a part of the rollout of the cellular network, we will be offering promotions to customers of the network to discount calls and texts. Selected users will be automatically enrolled in promotions offering discounted texts and calls to people that they frequently contact, such as friends and family. The users who will receive these promotions will be randomly selected once the network is launched. The promotions are only scheduled to begin some weeks after 
the initial launch of the network; moreover, registering for a SIM card is not a guarantee that they will receive a promotion.

\section{Step 3: Recording personal information}

Registration Assistants will be provided with a tablet containing a brief survey filled out through the SurveyCTO application. The survey asks you for identification details of the customer and matches these with names in a central database containing all the barangay residents interviewed in a community-wide survey in 2016. The details to be entered into the survey are below:

- First name

- Last name

- Nickname

- Age

- Gender

- Municipality of residence

- Barangay of residence

- Sitio of residence

After entering these details, the survey form will automatically search for the names of the registrant in the database. If the name of the registrant is found, it will display on the screen of the tablet. However, if there are multiple names in the database that are similar to the name entered, you will need to select the correct name from the list. The form should display the unique identifiers available: first name, last name, and particularly age, to confirm the registrant's identity.

If the name is not found, then the registration staffers must first confirm with barangay representatives or other members of the community that this individual genuinely resides in the site assigned a cell phone tower. Only residents of this site will be allowed to receive a SIM card.

If this information is verified, the form will then allow you to record the name and other details as a new entry in the database before assigning it a unique cell phone number. Inform the IPA Project Manager of all individuals that were not found in the database. We will require that an IPA Enumerator carry out a survey with that individual.

Some promotions may be available to certain contacts that the household designates. Ask the user for the following details for the seven contacts that he/she would most like to be able to contact if discounted texts and calls are made available:

- Last name

- First name 
- Nickname

- Gender

- Cell phone number

- Location

Record these details in the survey form. If they do not know the cell phone number of this contact, inform them that the numbers are needed as much as possible if they would like to avail of these promotions. The registrant will not need to fill out seven contacts, but you should encourage them to try to register the maximum number of seven.

As before, the form will automatically search for the names of the seven contacts in the database provided. If the name is not in the database, you will be given the option to create a new entry for the name and enter all the details provided.

Note that each individual subscriber may be given only one (1) SIM card. If additional household members intend to get SIM cards, then these individuals must register as well.

\section{Step 4: Verification}

At the table, a final review of the information provided must be conducted. Additionally, a member of the registration team should ensure that all individuals are familiar with how to use their SIM card and have information about where to obtain top-up credit.

\section{Step 5: Baseline Survey}

If any households are unable to be identified in the baseline database, a Registration Staffer must carry out a household survey with the head of the household or the spouse of the head of the household. It is preferable that the household survey is conducted on the day of the community registration event. However, if time is short an appointment can be made to conduct the baseline survey at a later date. As with the baseline census, the enumerator should carry out the survey in a manner that ensures the privacy and confidentiality of the respondent. A visit to the dwelling of the household will be necessary in order to obtain GPS coordinates.

Note that these baseline surveys will only be conducted for households that were not included in the baseline surveys in 2016 and 2018, and therefore cannot be found in our database. If there are individuals who cannot be located in the database, but can be traced to existing households, then we will register these individuals and provide them with SIM cards, but there is no need to conduct a baseline survey.

\section{Follow-up Registration}

After the initial registration process, E-Load Vendors will be responsible for handing out SIMs to eligible members of the community. They will be recording the details of registrants, asking them to fill out a paper form containing all the information that registrants 
filled out in Phase 1. The retailers will be requested to keep these forms for periodic collection by a member of the cooperative. The cooperative will then periodically send the forms to town and to Manila in order for the personal identification data to be entered manually. Members of the research team will eventually return to the community to conduct the online registration manually with these individuals.

\section{Step 1: Training the vendors}

There will be about 1-2 vendors per site which will be the official retailers of e-load and SIM cards in the community. These vendors will be trained in how to collect data using paper forms.

The registration team from IPA will then instruct the vendors that having the registrant fill out the form is crucial to the operation of the project. The vendors must be instructed before the staff leaves the SIM cards with them. If paper forms, we need a method of collection and verification Managing non-treatment households.

\section{Step 2: Turnover of SIM cards}

After the community event, any preassigned and unclaimed SIM cards will be handed over to one vendor who has been selected in advance, and who ideally lives in an area that is most accessible to the greatest number of residents. Make sure that there are control mechanisms for the transfer of the SIM cards to the vendor. Provide the vendor with an acknowledgement receipt that he/she has received the SIM cards.

\section{Step 3: Customer claims SIM card}

In this step, we assume that a customer has visited the vendor to claim a SIM card. The vendor must first get the customer's name and household head and cross-check with the vendor's inventory or list to see if there is a pre-assigned SIM card for the customer.

If the customer was part of the baseline, then there will be a pre-assigned SIM attached to their name, and the vendor must first collect information from the customer using the survey form (same as Table 1 during the community event). The vendor will then hand over the SIM to the customer. Finally, the vendor will ensure that the customer has signed the waiver/subscriber conforme form.

If the customer was not part of the baseline, then the vendor would need to inform the customer that he will be visited by an IPA enumerator to verify his residential status. If possible, get information from the customer on when would be the best time for the IPA visit. If the customer is eligible, the IPA enumerator will give the SIM on the same day as the visit.

\section{Step 4: IPA due diligence}

If the customer is not part of the baseline, an IPA enumerator will visit the household to verify the residential status. If customer is eligible, IPA will conduct a survey of the 
household. After the survey, the IPA staff will give the SIM cards and assist the customer in the SIM activation process. The IPA staff will then record the customer's assigned phone number and ensure that the customer has signed the waiver/subscriber conforme form.

\section{Providing E-Load and Working with Vendors}

In order to maintain a properly functioning cellular network, customers need to be able to add credit to their account. E-Load will be sold through local vendors. Customers can purchase E-Load from participating vendors in their community. When necessary, vendors can assist customers to load the top-up credit to the customer's account.

Local E-load vendors will also be introduced during the event so that people will be familiar where they can top-up their accounts. 


\subsubsection{Script for Registration}

Hello! We're going to give you your new SIM and we'll help you activate it as well. First, as part of the NTC regulatory requirements, we are informing you that this is a test and an experimental network and the grade of service may NOT be the same as those of conventional networks. Here's a copy of the waiver/subscriber conforme, kindly affix your name and signature below.

(Customer signs. There should be two copies. Give one copy to the customer)

Here is your new SIM card! Please insert it into your phone.

(Staff would then assist the customer to follow the step-by-step instructions stated in this SIM provisioning guide)

You have now activated your SIM! As stated in the text message, your number is 09XXXXXXX.

(Staff will input the number on the form)

Finally, to celebrate the launch of the new network, we will be offering several different promos in the coming months. Subscribers will be selected through a lottery system for the opportunity to avail of one specific promo each. Please refer to this flyer for more information on the promo opportunities. Some of subscribers will receive promos for a certain number of free text messages, some will receive promos to use for a select group of friends and family members, some will receive promos to contact people living outside the network. In the coming months, look for a text message on your phone notifying you of your promo.

Thank you. Please proceed to the next table for the final step. 


\subsubsection{Customer Agreement}

Rules and Guidelines on using the KONEKT Barangay Promo SIM (English Translation)

1. To be able to use the services offered by the Konekt Barangay Promo SIM, you must have the following:

(a) A working GSM 900 or multiband cellphone

(b) A working Konekt Barangay Promo SIM

(c) Konekt Barangay Promo SIM prepaid load credit

2. The Konekt Barangay Promo SIM is a promo of GK Mabuhay and may not provide the same quality of service as the conventional Globe or TM Prepaid SIM. The Konekt Barangay Promo SIM will only work within a $300-500 \mathrm{~m}$ radius from the location of the Konekt Barangay base station site. The Konekt Barangay Promo SIM allows you to:

(a) Call to other mobile and landline numbers within the Philippines

(b) Receive calls from other mobile numbers within the Philippines

(c) Send texts (SMS) from any Globe or TM mobile number within the Philippines. Texts from other operators (non-Globe/TM) will not be received.

(d) The Konekt Barangay Promo SIM will not work if you are outside the $500 \mathrm{~m}$ radius from the base station

(e) You cannot make or receive calls from outside the Philippines

(f) You cannot avail any Globe/TM value added services and promotions such as ring-back tones, etc.

3. The Konekt Barangay Promo SIM is a promo that may start anytime from [START DATE] until [END DATE]. Globe reserves the right to terminate the promo and selling of the Konekt Barangay Promo SIM and load at any time and date after the promo period. Because this is a promo service, Globe may terminate the service at any time and Globe is not obliged to finish the promo period.

4. The Konekt Barangay Promo SIM can be bought at its suggested retail price (SRP) of Php 15.00 from your local retailer.

5. The use of the services of the Konekt Barangay Promo SIM has a corresponding cost. Globe may change the service rates, with the approval of the National Telecommunications Commission (NTC), without any notifications to its subscribers.

6. The Konekt Barangay Promo SIM has its own retails and load sellers. Prepaid load for the Konekt Barangay Promo SIM is not available from the Globe/TM loading outlets. You cannot also buy prepaid load using Globe Autoload Max. 
Network Interaction Type

Tariff (PHP)

Call from a Konekt number to another Konekt number

$1.00 /$ minute

Call from a Konekt number to a long-distance on-network number

$3.00 /$ minute

Call from a Konekt number to an long-distance off-network number

$5.50 /$ minute

Text from Konekt number to Konekt number

$0.25 /$ message

Text from Konekt number to long-distance on-network number

$0.50 /$ message

Text from Konekt number to long-distance off-network number

All incoming calls

$1.00 /$ message

FREE

Incoming text messages (on-network local and long-distance)

FREE

Incoming text messages (off-network)

NOT ALLOWED

7. It is the responsibility of the SIM and phone owner to protect his/her own mobile phone, SIM and its corresponding PIN/PUK from load theft and unauthorized load usage. All calls, SMS and other transactions will be charged accordingly.

8. You shall not use the Konekt Barangay SIM or Load for any unlawful, fraudulent, elicit or abusive purpose. The Konekt distributor or partner may terminate the service of any subscriber who shall exhibit abusive usage.

9. The Konekt Barangay load of any subscriber who deliberately violates the terms and conditions stated in this document will be voided. The Konekt partner will not return any value or load to the offending subscriber.

10. Globe Telecom reserves the right to amend these terms and conditions at any time, with or without prior notice.

11. The Konekt Barangay Promo SIM is owned by Globe and uses new technology to provide cellular access to previously unserved sites.

12. By using the Konekt Barangay Promo SIM, the following information will be stored in a cloud server owned by a third-party:

(a) Konekt barangay number and all called or texted numbers

(b) Details of all calls, SMS, and data made/used through the Konekt Barangay Promo SIM

(c) Details of sending/receiving load

13. You will continue to enjoy your Konekt SIM card by ensuring that your SIM card is loaded. The Konekt SIM card will expire if you fail to reload within 60 days from the initial activation and use. The Konekt SIM card will also expire if you fail to load within 120 days after the date you had a zero account balance. Once a SIM card expires, it is automatically deactivated and the phone number cannot be used anymore.

14. Since the network and services of the Konekt Promo service is powered by experimental technology, Globe cannot ensure 24/7 operation and fast network restoration in the event of typhoons, rains, earthquakes and other acts of God. 
15. Globe will not be responsible for any service disruptions caused by any untoward incidents like typhoons, earthquakes, fire, terrorism, or force majeure.

Subscriber:

Name, Signature, Date 


\subsubsection{VBTS FAQ Responses}

What is the KONEKT Barangay SIM?

The KONEKT Barangay SIM is a SIM for currently unserved barangays that do not have cellular access.

How to activate the Konekt Barangay SIM?

Type in the keyword 'Barangay' and send to 101.

Ex: Barangay (send to: 101)

Afterwards, you will receive a text with the following message: "You can now use your KONEKT barangay SIM. Your number is 0936-1xxxxxx."

Where can I top-up my prepaid load?

You can top-up your credit at accredited KONEKT Barangay load retailers.

How can I send load to another mobile subscriber?

You can also Share-a-Load via text:

STEP1: Type in $<$ destination mobile number $><$ space $><*$ amount $>$

STEP2: Send to 102.

Example: $09361234567 * 10$ (Send to: 102)

\section{How do I check my load balance?}

Type BAL and send to 103.

Ex: BAL (send to: 103)

Afterwards, you will receive a text with the following message: "Your balance is Php xx."

\section{How do I check my phone number?}

Type NUM and send to 104

Ex: NUM (send to: 104)

Afterwards, you will receive a text with the following message: "Your number is 0936XXXXXX"

How does the service compare to commercial operators such as Globe/Smart? The VBTS network is a pilot network that is being tested in your barangay. The technical capabilities of the VBTS system are [less robust] than a fully operational commercial tower.

\section{Will VBTS be offering any promos like Globe/Smart?}

As part of the piloting process, the VBTS network will offer certain pilot promos to a limited number of families living in the same household. These promos will be randomly assigned to some (but not all) families in the barangay/sitio, and will be available for a limited time only. Should you be selected for a pilot promo, you will be contacted via SMS.

Which texts and calls are considered on and off network?

Text and calls placed from a user from within the VBTS network on a VBTS SIM to other 
SIMs within the VBTS networks [list sitios?] are considered on network. Both the sender and receiver must both have VBTS SIMs and be physically located within the VBTS network at the time of the text/call. Any calls/texts placed from within the VBTS network to people with non-VBTS SIMs (i.e. Globe/Smart) are considered off network. Any calls/texts placed from VBTS SIMs when the sender is physically located outside the VBTS network (for example, in Baler) are also considered off-network.

\subsubsection{Promo prompts}

Free 5 text messages Congratulations! You are eligible for the Free5 promo. You have free 5 texts to Globe and 5 texts to other networks. To learn more, text INFO FREE5 to 555. To opt out, text REMOVE FREE5 to 555. (Congratulations! Maari mo nang ma-enjoy ang Free5 promo! Meron kang libreng 5 texts sa Globe at 5 texts palabas ng ibang networks! For more info, i-text ang INFO FREE5 at $i$-send sa 555. Kung ayaw mong matanggap ang promo na ito, text REMOVE FREE5 at i-send sa 555.)

Free Load: Thank you for being a VBTS subscriber. As a one-time promotion, your account has been credited with Php 100 free e-load! You may use the e-load however you wish. The eload will be credited to your account within 72 hours.(Bilang pasasalamat sa pagiging VBTS subscriber, ang iyong SIM ay makakatanggap ng libreng Php 100 e-load! Maaring magamit ang load sa pangtawag/text sa kahit anong network. Ang e-load ay matatanggap sa loob ng 72 na oras.)

Local Discount: Congratulations! You are eligible for the GoLocal discount. For the next 30 days, all local calls and text messages will be discounted by $50 \%$. To learn more, text INFO GL to 555. To opt out, text REMOVE GL to 555. (Congratulations! Maari mo nang ma-enjoy ang GoLocal promo! Sa loob ng 30 days, 50\% off ang texts at calls mula VBTS to VBTS network. For more info, text INFO to 555. Kung ayaw mong matanggap ang promo na ito, text REMOVE GL at i-send sa 555.)

Long Distance Discount: Congratulations! You are eligible for the GoLongDistance discount. For the next 30 days, all long-distance calls and text messages will be discounted by $50 \%$. To learn more, text INFO GLD to 555. To opt out, text REMOVE GLD to 555. (Congratulations! Maari mo nang ma-enjoy ang GoLongDistance promo! Sa loob ng 30 days, $50 \%$ off ang texts at calls mula VBTS palabas ng ibang network. For more info, $i$-text ang INFO GLD at $i$-send sa 555. Kung ayaw mong matanggap ang promo na ito, text REMOVE GLD at i-send sa 555.) 


\subsubsection{Promotional Materials}
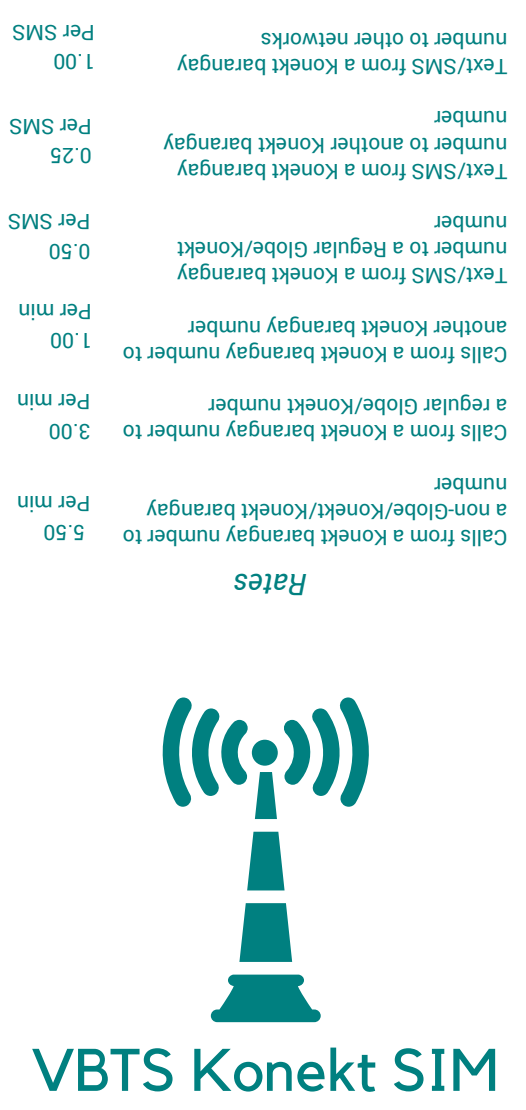

[ The Village Base Station Project ]

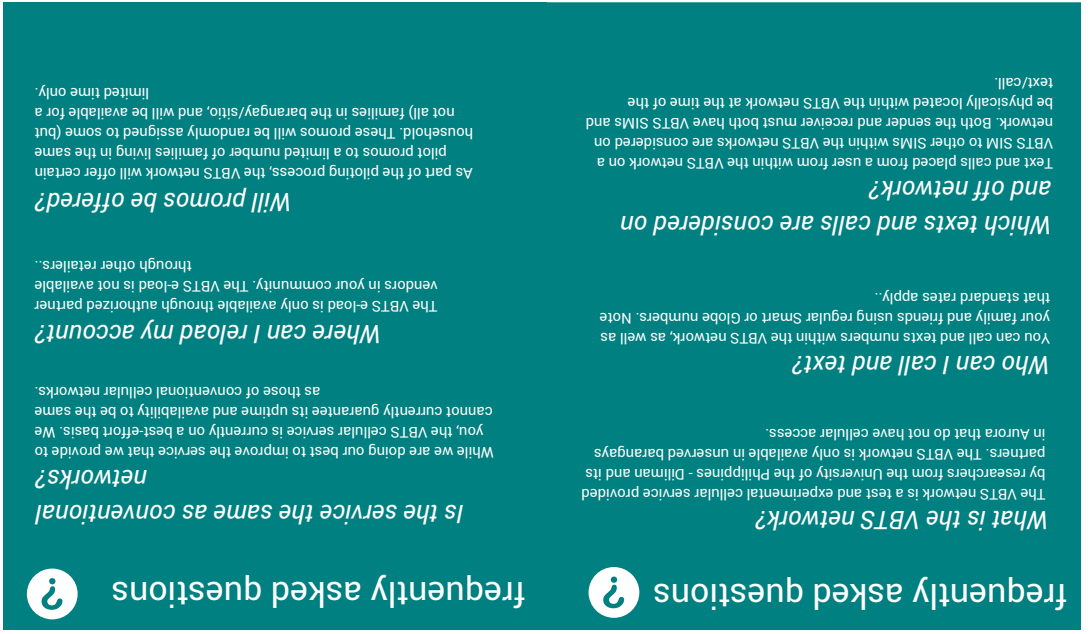

How to activate your SIM

- Type the keyword "BRGY" and send to 101

- You will receive a

confirmation along with your number via text

Balance Inquiry

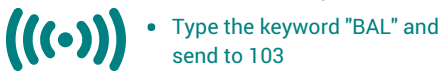

Number Inquiry

- Type the keyword "NUM" and send to 104

Promo Information

- Type the keyword "PROMO" and send to 555

How to send Load

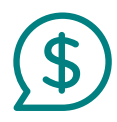

- Type in <destination mobile number $><$ space $><* a m o u n t>$ and send to 102

- Example "09361234567 *10" (send to 102)

\section{Emergency Contacts}

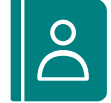

Samahan +63-91234567890

Pamana +63-91234567890

VBTS +63-91234567890

hotline $\quad+63-91234567890$

+63-91234567890

Figure 3: VBTS Konekt Flyer 


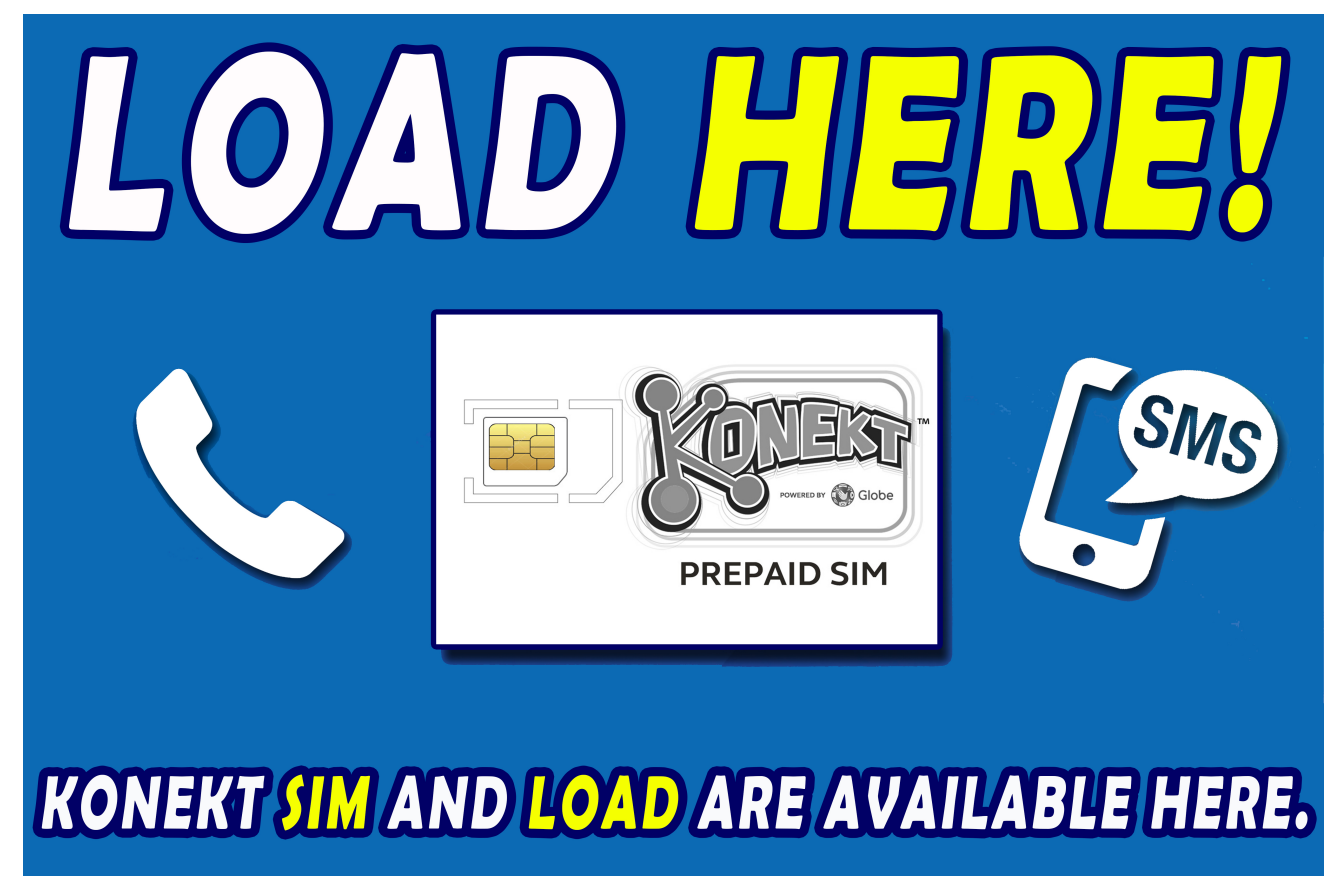

Figure 4: VBTS Konekt Retailer Poster

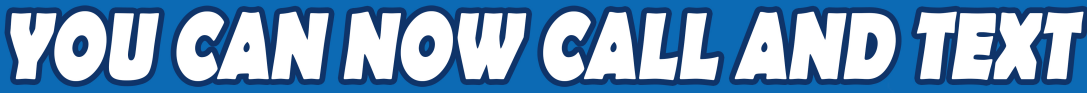

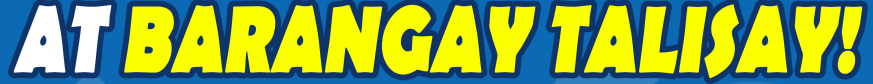

1. The Konekt BARANGAY SIM is a SIM that can be purchased on selected stores in selected barangays.

2. Sign the Sulpscriber Terms \& Conditions (T\&C) Form to get your SIM.

3. To activate, just text the word "Barangay" and send it to 101. No load is required. 4. You will get a registration confirmation through text that contains your KONEKT BARANGAY mobile number:

5. You can purchase your load from selected stores in your barangay.

6. Once you have a load, you can use your KONEKT BARANGAY SIM to call and text.

\begin{tabular}{|c|c|}
\hline & \\
\hline TM & Pnpo \\
\hline tw & Pho 100 per text \\
\hline & Pho 1.00 per min \\
\hline & Php 3 \\
\hline to Othe & Php 5.50 per minu \\
\hline
\end{tabular}

Figure 5: VBTS Konekt Tariff Advertisement 
8.2 Baseline Household and Adult Survey 


\section{INNOVATIONS FOR POVERTY ACTION}

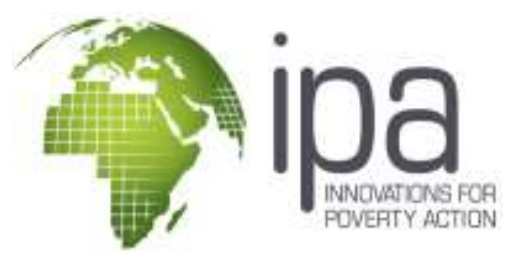

\section{CONNECTING ISOLATED COMMUNITIES 2016 - BASELINE SURVEY}

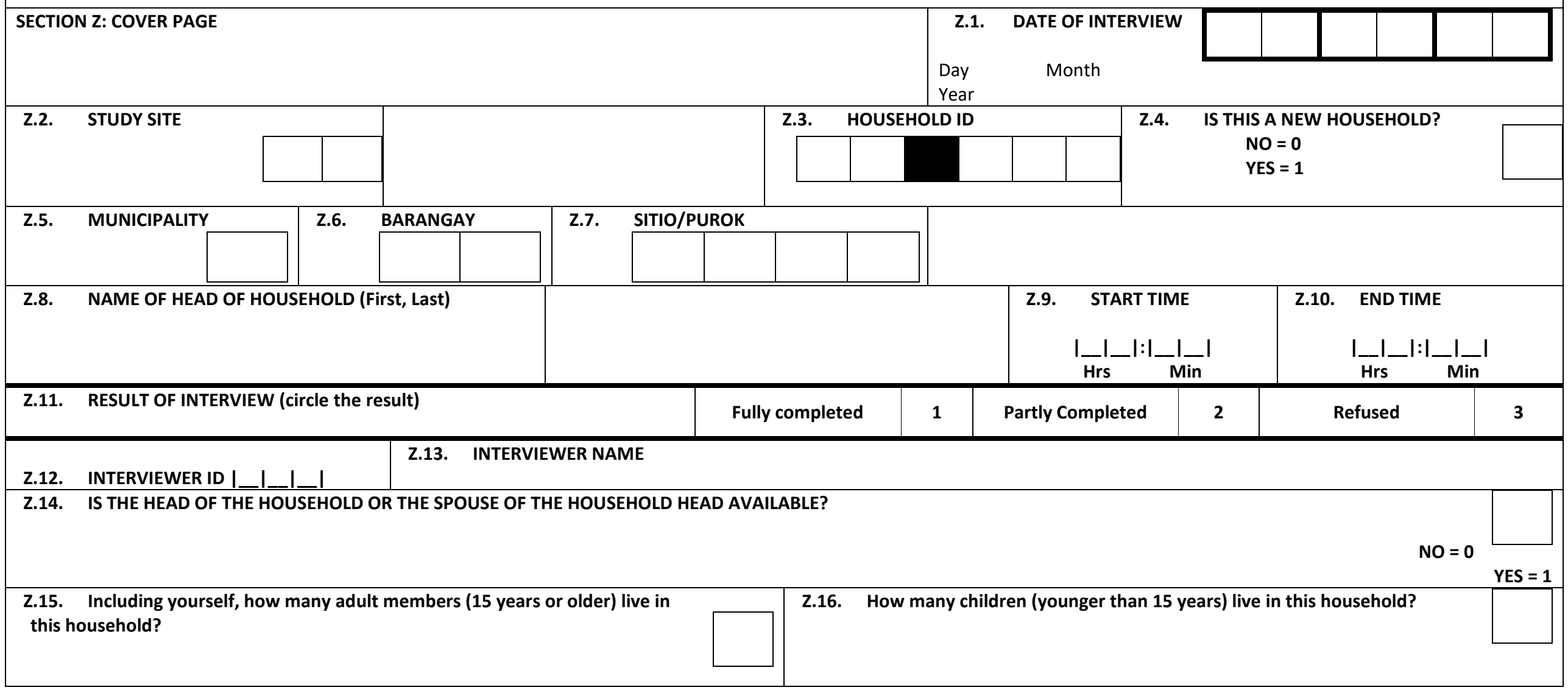

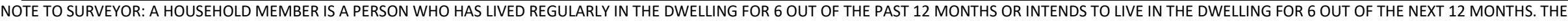
HOUSEHOLD HEAD IS THE INDIVIDUAL WITH PRIMARY RESPONSIBILITY FOR DECISIONS ABOUT HOUSEHOLD FINANCES. 


\section{SECTION A. HOUSEHOLD LISTING AND DEMOGRAPHIC INFORMATION}

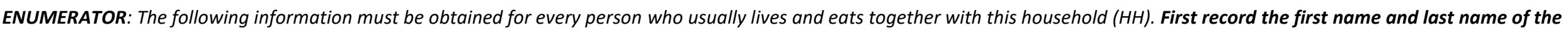

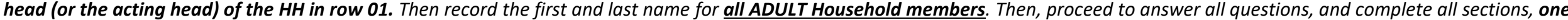
person at a time, following the instructions and skips. If an individual adult is available, each person should answer the questions related to him/her.

\begin{tabular}{|c|c|c|c|c|c|c|c|c|}
\hline & A.1. & A.2. & A.3. & A.4. & A.5. & A.6. & A.7. & A.8. \\
\hline 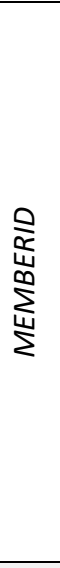 & FIRST NAME & $\begin{array}{l}\text { LAST } \\
\text { NAME }\end{array}$ & NICKNAME & $\begin{array}{l}\text { Is [NAME] male } \\
\text { or female? } \\
1 \text { Male } \\
2 \text { Female }\end{array}$ & $\begin{array}{l}\text { What is } \\
\text { [NAME]'s age? } \\
\text { (Age in years } \\
\text { at last birthday) }\end{array}$ & $\begin{array}{l}\text { Relationship to the head of household } \\
1 \text { Head of Household } \\
2 \text { Wife or husband } \\
3 \text { Son or daughter } \\
4 \text { Son-/daughter-in-law } \\
5 \text { Grandchild } \\
6 \text { Father or Mother } \\
7 \text { Nephew or Niece } \\
8 \text { Brother or sister } \\
9 \text { Brother-/sister-in-law } \\
10 \text { Other relative } \\
11 \text { Unrelated member }\end{array}$ & $\begin{array}{l}\text { Does [NAME] usually live } \\
\text { here in this dwelling? } \\
\text { Usually means that an } \\
\text { individual ate meals out of } \\
\text { the same pot of food as the } \\
\text { household at least } 4 \text { of the } \\
\text { last } 7 \text { days and slept in the } \\
\text { dwelling at least } 4 \text { of the last } \\
7 \text { nights. If the previous week } \\
\text { was not a typical week, ask } \\
\text { this question about the last } \\
\text { typical week. } \\
0 \text { No } \\
1 \text { Yes }\end{array}$ & 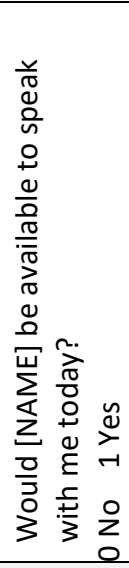 \\
\hline 01 & & & & $I_{-} I$ & I_I_I_I & $I_{-} I_{1}$ & $I_{-}$ & 1 \\
\hline 02 & & & & $I_{1}$ & I_I_I_I_ & $I_{1}$ & $I_{1}$ & 1 \\
\hline 04 & & & & 1 & I__ I_ I_ & 1 & 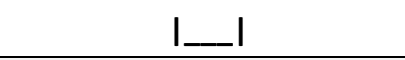 & 1 \\
\hline 05 & & & & I_ I & I___ I__ & 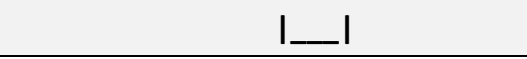 & $I_{-}$ & $I$ \\
\hline 06 & & & & I_I & I_I_I_I_ & I_ I & I_I & $I$ \\
\hline 07 & & & & I_ I & I__ I__ & 1 & 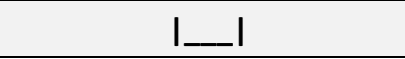 & 1 \\
\hline 08 & & & & 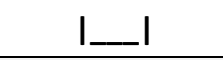 & I__ I_ I & 1 & $I$ & 1 \\
\hline 09 & & & & I_I & I_I_I_I & 1 & $I_{-}$ & $I$ \\
\hline 10 & & & & 1 & I__ I_ & 1 & I_I & 1 \\
\hline 11 & & & & 1 & I__ I_ & $I$ & 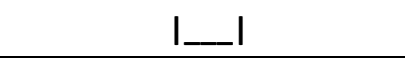 & 1 \\
\hline 12 & & & & $I$ & I_I_I_I_ & $I_{-}$ & $I_{-}$ & $I_{1}$ \\
\hline
\end{tabular}


PROJECT SITE I______ I

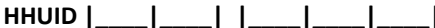

\begin{tabular}{|c|c|c|c|c|c|c|c|c|c|}
\hline & A.9. & A.10. & A.11. & A.12. & A.13. & A.14. & A.15. & A.16. & A.17. \\
\hline 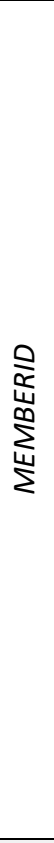 & $\begin{array}{l}\text { Where does [NAME] } \\
\text { usually live? } \\
1 \text { In the same } \\
\text { sitio/barangay } \\
2 \text { In neighboring } \\
\text { barangay } \\
3 \text { In Baler } \\
4 \text { In Dingalan } \\
5 \text { In Manila } \\
\text { Other }\end{array}$ & $\begin{array}{l}\text { How long } \\
\text { has [NAME] } \\
\text { lived there? }\end{array}$ & $\begin{array}{l}\text { How long } \\
\text { has } \\
\text { [NAME] } \\
\text { lived } \\
\text { here? }\end{array}$ & $\begin{array}{l}\text { What is the highest grade } \\
\text { level completed by [NAME]? } \\
0 \text { No formal schooling } \\
1 \text { Some elementary (did not } \\
\text { graduate/complete } \\
\text { elementary) } \\
2 \text { Elementary graduate } \\
3 \text { Some high school (did not } \\
\text { graduate/complete high } \\
\text { school) } \\
4 \text { High school graduate } \\
5 \text { Vocational training } \\
6 \text { Some college or higher } \\
7 \text { College graduate } \\
-88 \text { Refused } \\
-77 \text { Don't Know/Uncertain } \\
\text { [Prefilled } \\
\text { Update if necessary] }\end{array}$ & $\begin{array}{l}\text { Has [NAME] } \\
\text { worked or } \\
\text { attended } \\
\text { school } \\
\text { outside of } \\
\text { the barangay } \\
\text { in the last } 12 \\
\text { months? } \\
1 \text { Worked } \\
2 \text { Attended } \\
\text { school } \\
3 \text { Both } \\
\text { worked and } \\
\text { attended } \\
\text { school } \\
4 \text { Neither }\end{array}$ & $\begin{array}{l}\text { Where did } \\
\text { [NAME] } \\
\text { work? } \\
1 \text { In } \\
\text { neighboring } \\
\text { barangay } \\
2 \text { In Baler } \\
3 \text { In } \\
\text { Dingalan } \\
4 \text { In Manila } \\
\text { Other }\end{array}$ & $\begin{array}{l}\text { Where did } \\
\text { [NAME] } \\
\text { attend } \\
\text { school? } \\
1 \text { In } \\
\text { neighboring } \\
\text { barangay } \\
2 \text { In Baler } \\
3 \text { In } \\
\text { Dingalan } \\
4 \text { In Manila } \\
\text { Other }\end{array}$ & $\begin{array}{l}\text { In the last } \\
\text { completed, } \\
\text { week, } \\
\text { What was } \\
\text { [NAME]'s } \\
\text { primary } \\
\text { occupation? } \\
0 \text { Did not } \\
\text { work/stayed at } \\
\text { home } \\
1 \text { Farming } \\
2 \text { Fishing } \\
3 \text { Construction/ } \\
\text { road } \\
\text { maintenance } \\
4 \text { Logging } \\
5 \text { Professional } \\
\text { work } \\
6 \text { Student } \\
\text { Other }\end{array}$ & $\begin{array}{l}\text { Location of } \\
\text { work } \\
1 \text { In the same } \\
\text { sitio/barangay } \\
2 \text { In neighboring } \\
\text { barangay } \\
3 \text { In Baler } \\
4 \text { In Dingalan } \\
5 \text { In Manila } \\
\text { Other }\end{array}$ \\
\hline 01 & & & & $I \_I \_I$ & 1 & $I_{-} I_{-} \mid$ & 1 & I_I_I_I & \\
\hline 02 & & & & I_I_I_I & 1 & I__l_l_l & 1 & I_I_I_ & \\
\hline 03 & & & & I_I_I_I & I_I & I_I_I & I_I & I_I_I_I & \\
\hline 04 & & & & I_I_I & $I \ldots I$ & I_I_I & $I \ldots I$ & I_I_I & \\
\hline 05 & & & & I_I_I & $I \ldots I$ & I_I_I & $I \ldots I$ & I_I_I_I & \\
\hline 06 & & & & I_I_I_I & I_I & I_I_I & $I$ & I_I_I & \\
\hline 07 & & & & I_I_I_I & 1 & $I_{-} I_{-} I_{1}$ & $I_{\ldots} I$ & I_I_I_L & \\
\hline 08 & & & & I___ I_ & 1 & $I_{1} I_{-} I_{1}$ & $I$ & I_____ & \\
\hline 09 & & & & 1 & 1 & I_I_I & 1 & 1 & \\
\hline 10 & & & & I_I_I_ I & 1 & I_____ I & $I$ & I_I_I_I_L_ & \\
\hline 11 & & & & I_I_I_I & $I_{-}$ & I_I_I_I & 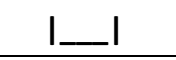 & I_I_I_L_ & \\
\hline 12 & & & & $I \_I \_I$ & $I \ldots I$ & 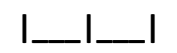 & $I \ldots I$ & $I$ & \\
\hline
\end{tabular}

CCN Baseline Survey - Page 3 of 16 - Version: 2016-07-20 


\begin{tabular}{|c|c|c|}
\hline & A.18. & A.19. \\
\hline 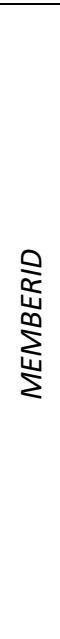 & $\begin{array}{l}\text { Does [NAME] plan to travel outside of the barangay } \\
\text { for any reason in the next } 12 \text { months? } \\
0 \text { No } \\
1 \text { Yes }\end{array}$ & $\begin{array}{l}\text { What are the reasons [NAME] would travel in the } \\
\text { next } 12 \text { months? } \\
\text { SELECT MULTIPLE } \\
1 \text { For work (permanent, } 3 \text { months or longer) } \\
2 \text { For work (temporary, less than } 3 \text { months) } \\
3 \text { For school } \\
4 \text { To socialize with friends, family, or others } \\
5 \text { To sell goods } \\
6 \text { To buy agricultural inputs } \\
7 \text { To shop for general household shopping } \\
8 \text { For a financial transaction (at the bank or } \\
\text { to make/receive a payment) } \\
9 \text { For medical or health reasons } \\
\text { Other (Specify) }\end{array}$ \\
\hline 01 & $I_{-} \mathrm{I}$ & I__lil__lil__lil__lil__ \\
\hline 02 & $I \ldots I$ & I__lil_lil_lil__lil__ \\
\hline 03 & $I \ldots I$ & I__lil_lil__lil__lil_l \\
\hline 04 & $I_{-}$ & 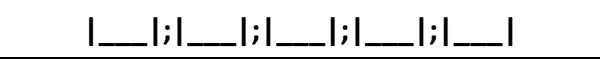 \\
\hline 05 & $I_{-} I$ & I__lil_lil__lil__lil__ \\
\hline 06 & $I_{-} I$ & I__lil_lil_lil_lil__ \\
\hline 07 & $I \ldots I$ & 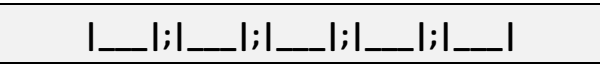 \\
\hline 08 & $I_{-}$ & l_lil_lil_lil__lil__ \\
\hline 09 & $I_{-}$ & I_lil_lil_lil__lil_l \\
\hline 10 & $I$ & 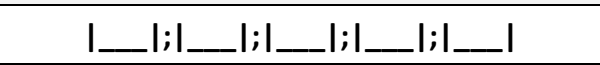 \\
\hline 11 & $I_{\ldots} I$ & I__l;I_l;i__lil_lil__ \\
\hline 12 & $I_{-} I$ & I_lil_l;i_lil__li___ \\
\hline
\end{tabular}




\section{SECTION B. Assets \& Phones}

B.1. $\quad$ How many separate rooms are there in this

household that are currently occupied or could be occupied?

(do not count bathrooms, toilets, storerooms and garage)

B.2. Does your household own land that you either live on or use for farming?

B.3. Who in your household owns land that you either live on or use for farming?

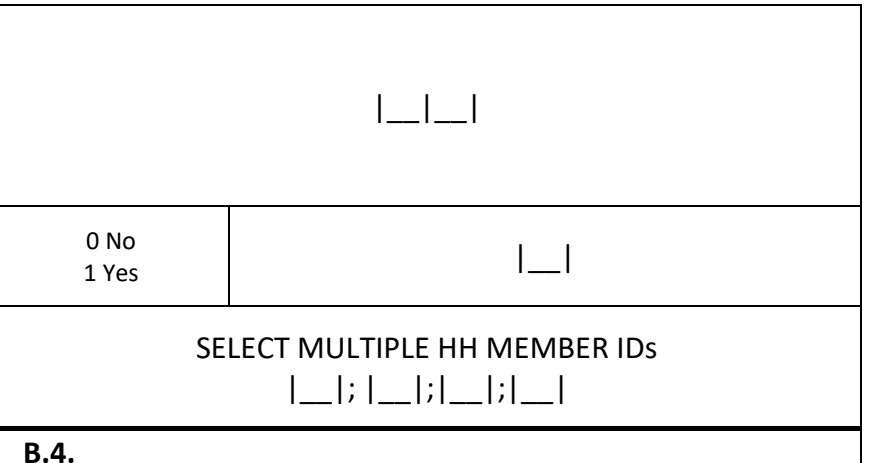

Does your household own any of the following?

0 No

1 Yes

\begin{tabular}{|c|c|c|}
\hline (i) & Sala sets & I_l \\
\hline (ii) & Refrigerator/freezer & 1 \\
\hline (iii) & Television set & $I_{\text {L_l }}$ \\
\hline (iv) & VTR/VHS/VCD/DVD player & 1 \\
\hline (v) & Radio & 1 \\
\hline (vi) & Satellite dish & I_L \\
\hline (vii) & Motorized vehicle (boat, car, tricycle motorbike) & $I_{-1}$ \\
\hline (viii) & Gas stove & 1 \\
\hline
\end{tabular}




\begin{tabular}{|c|c|c|c|}
\hline B.5. & Does your household have access to electricity in this dwelling? & $\begin{array}{l}0 \text { No } \\
1 \text { Yes }\end{array}$ & $1 \_1$ \\
\hline B.6. & How many cell phones does your household own? & \multicolumn{2}{|c|}{$I_{-1} I_{1}$} \\
\hline B.7. & Does your household own any SIM cards for cell phones? & $\begin{array}{l}0 \text { No } \\
1 \text { Yes }\end{array}$ & I_l \\
\hline B.8. & How many SIM cards does your household own? & \multicolumn{2}{|c|}{ I_I_I } \\
\hline B.9. & Which cell phone providers do these SIM cards come from? & $\begin{array}{l}1 \text { Globe } \\
2 \text { Smart } \\
3 \text { Sun } \\
4 \text { Touch Mobile (TM) } \\
5 \text { Talk and Text (TNT) } \\
6 \text { ABS-CBN Mobile } \\
\text { Other (Specify) }\end{array}$ & |_l; |_l;|_l;|_l \\
\hline
\end{tabular}


D.2.

In the past 12 months, what is

the SECOND most important

source of income for your

household?

1 Farming

2 Fishing

3 Logging

4 Other wage employment

5 Other self employment

6 Remittances/Gifts/Donations

from family or friends

7 Government assistance

8 Assistance from religious or

private organization

-98 Not applicable/none
D.3.

In the past 12 months, what is

the THIRD most important source

of income for your household?

1 Farming

2 Fishing

3 Logging

4 Other wage employment

5 Other self employment

6 Remittances/Gifts/Donations

from family or friends

7 Government assistance

8 Assistance from religious or

private organization

-98 Not applicable/none

-98 Not applicable/none

$$
\text { I____I }
$$

In the past 12 months, did you or a member of your

D.4. household receive any remittance or gift of cash from friends or family member?

In the past 12 months, did you or a member of your

D.6. household provide any remittance or gift of cash to friends or family member?

In the past 12 months, have you or has a member of your

D.8. household taken a loan from a financial institution such as microfinance institution or bank?

In the past 12 months, have you or has a member of your

D.10. household taken a loan from a friend, family member, or community member?

D.12. Does anyone in your household have a bank account with a bank?

I_I_I

I____ I

Remittance Codes: 1 In person in your sitio/purok; 2 In person in Baler; 3 In person in Dingalan; 4 In person elsewhere

5 Via Western Union, Cebuana Lhuiller, or other money transfer platform; Other (Specify)

Loan Codes: 1 Formal institution (such as a bank); 2 Employer; 3 Family member, friend, or community member; 4 Informal institution; Other (Specify)

Borrower Codes: 1 Employee; 2 Family member, friend, or community member; 3 Informal institution; Other (Specify) 
PROJECT SITE I_______

HHUID

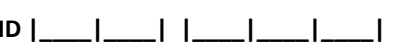

SECTION E. Emergency Preparedness

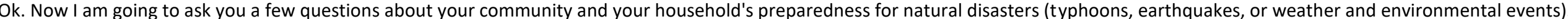

\begin{tabular}{|c|c|c|c|c|c|}
\hline E.1. & E.2. & E.3. & E.4. & E.5. & E.6. \\
\hline $\begin{array}{l}\text { How prepared do you feel } \\
\text { your community is if a natural } \\
\text { disaster were to hit your } \\
\text { barangay? } \\
1 \text { Very prepared } \\
2 \text { Prepared } \\
3 \text { Neither prepared nor } \\
\text { unprepared } \\
4 \text { Unprepared } \\
5 \text { Very unprepared }\end{array}$ & $\begin{array}{l}\text { If a typhoon were approaching this } \\
\text { region, how much advanced } \\
\text { warning do you expect you would } \\
\text { have? } \\
0 \text { None } \\
2 \text { Minutes } \\
3 \text { Hours } \\
4 \text { Days } \\
5 \text { Weeks } \\
6 \text { More than a month }\end{array}$ & $\begin{array}{l}\text { If evacuation were necessary, do } \\
\text { you think you would be able to } \\
\text { evacuate in time? } \\
\text { o No } \\
1 \text { Yes }\end{array}$ & $\begin{array}{l}\text { Has your household suffered } \\
\text { serious damage in the last year } \\
\text { from a typhoon? } \\
0 \text { No } \\
1 \text { Yes }\end{array}$ & $\begin{array}{l}\text { Have you or any other members of } \\
\text { your household or other relatives } \\
\text { held political or government office } \\
\text { in the past ten years? } \\
0 \text { No } \\
1 \text { Yes }\end{array}$ & $\begin{array}{l}\text { Which household members or } \\
\text { family members have held office. } \\
\text { Select all that apply. } \\
1 \text { Self } \\
2 \text { Spouse } \\
3 \text { Son } \\
4 \text { Daughter } \\
5 \text { Father } \\
6 \text { Mother } \\
7 \text { Grandfather } \\
8 \text { Grandmother } \\
9 \text { Brother } \\
10 \text { Sister } \\
11 \text { First Cousin } \\
12 \text { Uncle } \\
13 \text { Aunt } \\
14 \text { Nephew } \\
15 \text { Niece } \\
16 \text { In laws } \\
17 \text { Grandchild } \\
\text { Other }\end{array}$ \\
\hline I_I & I__ & I__ & I__ & I_I & I__l;I_I \\
\hline
\end{tabular}




\section{ADULT MODULE}

ENUMERATOR: ASK TO SPEAK WITH EACH OF THE ADULT MODULE RESPONDENTS IN PRIVATE.

\begin{tabular}{|c|c|c|}
\hline & G.1. & G.2. \\
\hline & $\begin{array}{l}\text { In the past } 12 \text { months, how frequently } \\
\text { did you leave [location_name] to visit } \\
\text {...? } \\
1 \text { Daily } \\
2 \text { Weekly } \\
3 \text { Monthly } \\
4 \text { A few times a year } \\
5 \text { Rarely (once or less a year) } \\
6 \text { Never }\end{array}$ & $\begin{array}{l}\text { For what purpose do you visit...? } \\
1 \text { For work (permanent, } 3 \text { months or longer) } \\
2 \text { For work (temporary, less than } 3 \text { months) } \\
3 \text { For school } \\
4 \text { To socialize with friends, family, or others } \\
5 \text { To sell goods } \\
6 \text { To buy agricultural inputs } \\
7 \text { To shop for general household shopping } \\
8 \text { For a financial transaction (at the bank or to make/receive a payment) } \\
9 \text { For medical or health reasons } \\
\text { Other (Specify) }\end{array}$ \\
\hline (i) The neighboring barangay & 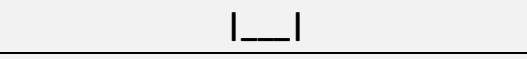 & $I \ldots$ \\
\hline (ii) Dingalan & I_I & I_I \\
\hline (iii) Baler & $I$ & I__ I \\
\hline (iv) Manila (3 years) & 1 & I_ I \\
\hline $\begin{array}{l}\text { (v) Any other place? } \\
\text { Specify: } \\
3 \text { Another barangay in the sam } \\
\text { Municipality: } \\
4 \text { Elsewhere in the Philippines } \\
\text { Province: } \\
5 \text { Outside of the Philippines } \\
\text { Other (Specify) }\end{array}$ & 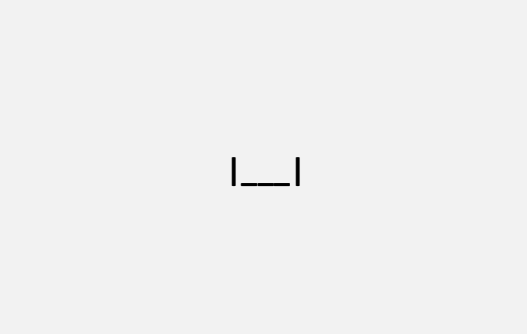 & I_l \\
\hline
\end{tabular}


L.1. How many different people, within the barangay, do you speak to on a regular basis?

These should be people that you know personally, not just acquaintances with whom you have occasional interactions.

\section{BARANGAY CONTACTS}

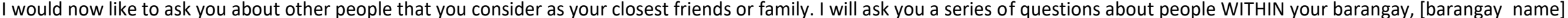

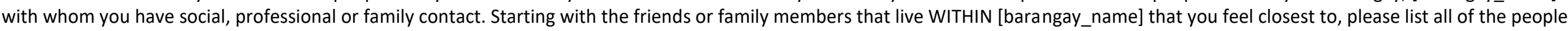

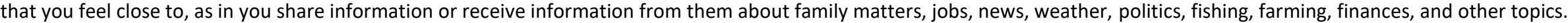

Excluding the people that you told me about within your household, what is the name of your \#1 closest friend or family member WITHIN [barangay_name]?

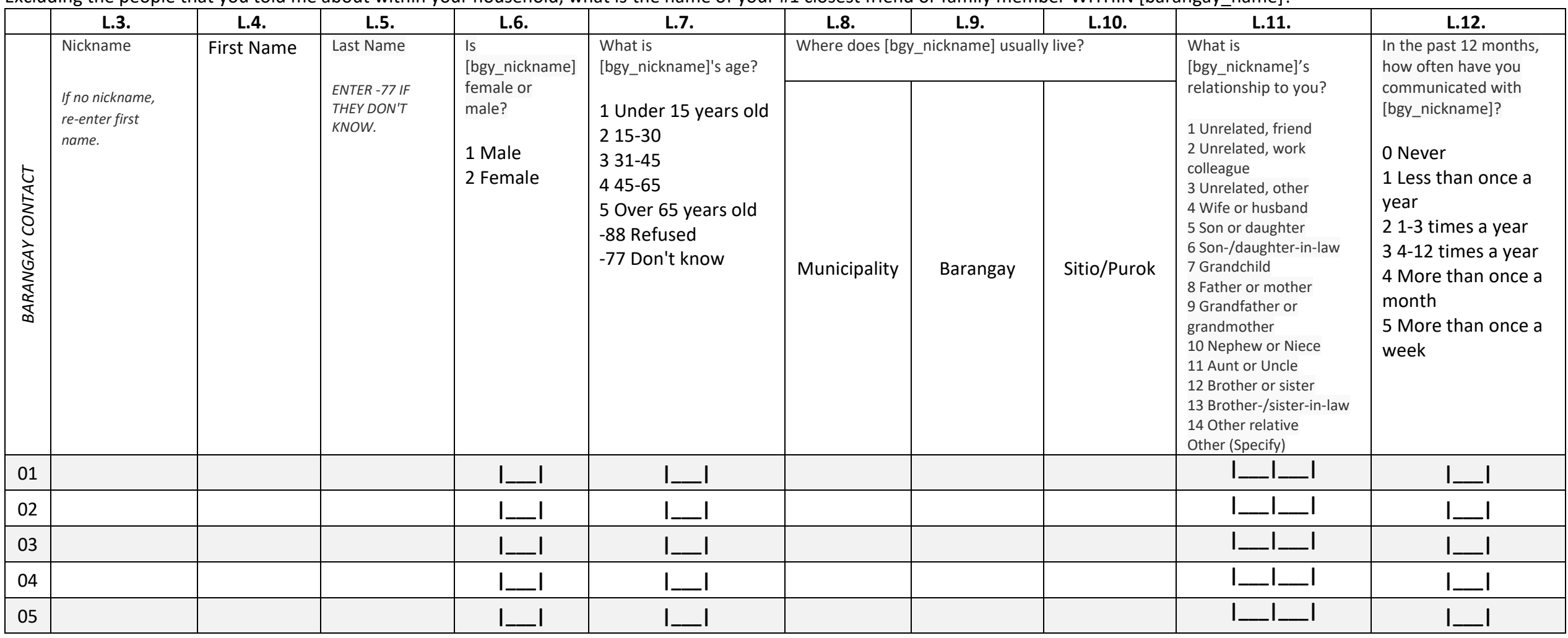

CCN Baseline Survey - Page 10 of 16 - Version: 2016-07-20 


\section{NON-BARANGAY CONTACTS}

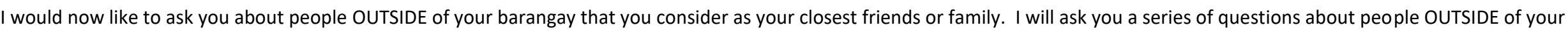

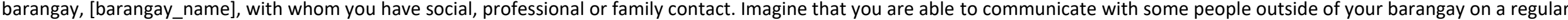

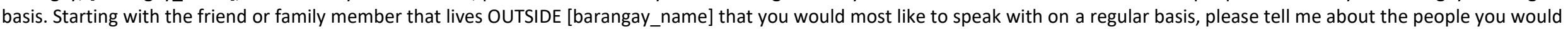
like to communicate with on a regular basis.

What is the name of your \#1 closest friend or family member OUTSIDE [barangay_name]?

\begin{tabular}{|c|c|c|c|c|c|c|c|c|c|c|c|}
\hline \multirow[b]{3}{*}{ 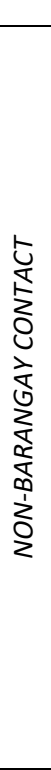 } & L.13. & L.14. & L.15. & L.16. & L.17. & L.18. & L.19. & L.20. & L.21. & L.22. & L.23. \\
\hline & \multirow[t]{2}{*}{$\begin{array}{l}\text { Nickname } \\
\text { If no } \\
\text { nickname, re- } \\
\text { enter first } \\
\text { name. }\end{array}$} & \multirow[t]{2}{*}{$\begin{array}{l}\text { First } \\
\text { Name }\end{array}$} & \multirow[t]{2}{*}{$\begin{array}{l}\text { Last Name } \\
\text { ENTER -77 IF } \\
\text { THEY DON'T } \\
\text { KNOW. }\end{array}$} & \multirow[t]{2}{*}{$\begin{array}{l}\text { Is } \\
\text { [nonbgy_nickname] } \\
\text { female or male? } \\
1 \text { Male } \\
2 \text { Female }\end{array}$} & \multirow{2}{*}{$\begin{array}{l}\text { What is } \\
\text { [nonbgy_nickname]'s } \\
\text { age? } \\
1 \text { Under } 15 \text { years } \\
\text { old } \\
215-30 \\
3 \text { 31-45 } \\
445-65 \\
5 \text { Over } 65 \text { years } \\
\text { old } \\
-88 \text { Refused } \\
-77 \text { Don't know }\end{array}$} & $\begin{array}{l}\text { Has } \\
\text { [nonbgy_nickname] } \\
\text { lived in this } \\
\text { barangay, } \\
\text { [barangay_name] } \\
\text { in the past three } \\
\text { years? }\end{array}$ & \multicolumn{3}{|c|}{$\begin{array}{l}\text { Where does [nonbgy_nickname] currently } \\
\text { live? }\end{array}$} & \multirow{2}{*}{$\begin{array}{l}\text { What is } \\
\text { [nonbgy_nickname]'s } \\
\text { relationship to you? } \\
1 \text { Unrelated, friend } \\
2 \text { Unrelated, work } \\
\text { colleague } \\
3 \text { Unrelated, other } \\
4 \text { Wife or husband } \\
5 \text { Son or daughter } \\
6 \text { Son-/daughter-in- } \\
\text { law } \\
7 \text { Grandchild } \\
8 \text { Father or mother } \\
9 \text { Grandfather or } \\
\text { grandmother } \\
10 \text { Nephew or Niece } \\
11 \text { Aunt or Uncle } \\
12 \text { Brother or sister } \\
13 \text { Brother-/sister-in- } \\
\text { law } \\
14 \text { Other relative } \\
\text { Other (Specify) }\end{array}$} & \multirow{2}{*}{$\begin{array}{l}\text { In the past } 12 \\
\text { months, how often } \\
\text { have you } \\
\text { communicated with } \\
\text { [nonbgy_nickname]? } \\
0 \text { Never } \\
1 \text { Less than once } \\
\text { a year } \\
2 \text { 1-3 times a year } \\
34-12 \text { times a } \\
\text { year } \\
4 \text { More than once } \\
\text { a month } \\
5 \text { More than once } \\
\text { a week }\end{array}$} \\
\hline & & & & & & & Municipality & Barangay & Sitio/Purok & & \\
\hline 01 & & & & $I \ldots I$ & $I_{\ldots} \mathrm{I}$ & & & & & I_I_I I & I_I \\
\hline 02 & & & & I_I & 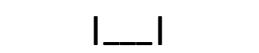 & & & & & I_I_I_L & I_I \\
\hline 03 & & & & I_I & $I$ & & & & & I___ا_I_ & I_I \\
\hline 04 & & & & $I$ & $I$ & & & & & I_L_ا_I_L & I_I \\
\hline 05 & & & & I_I & $I$ & & & & & I_I_I_I_ & I_I \\
\hline
\end{tabular}




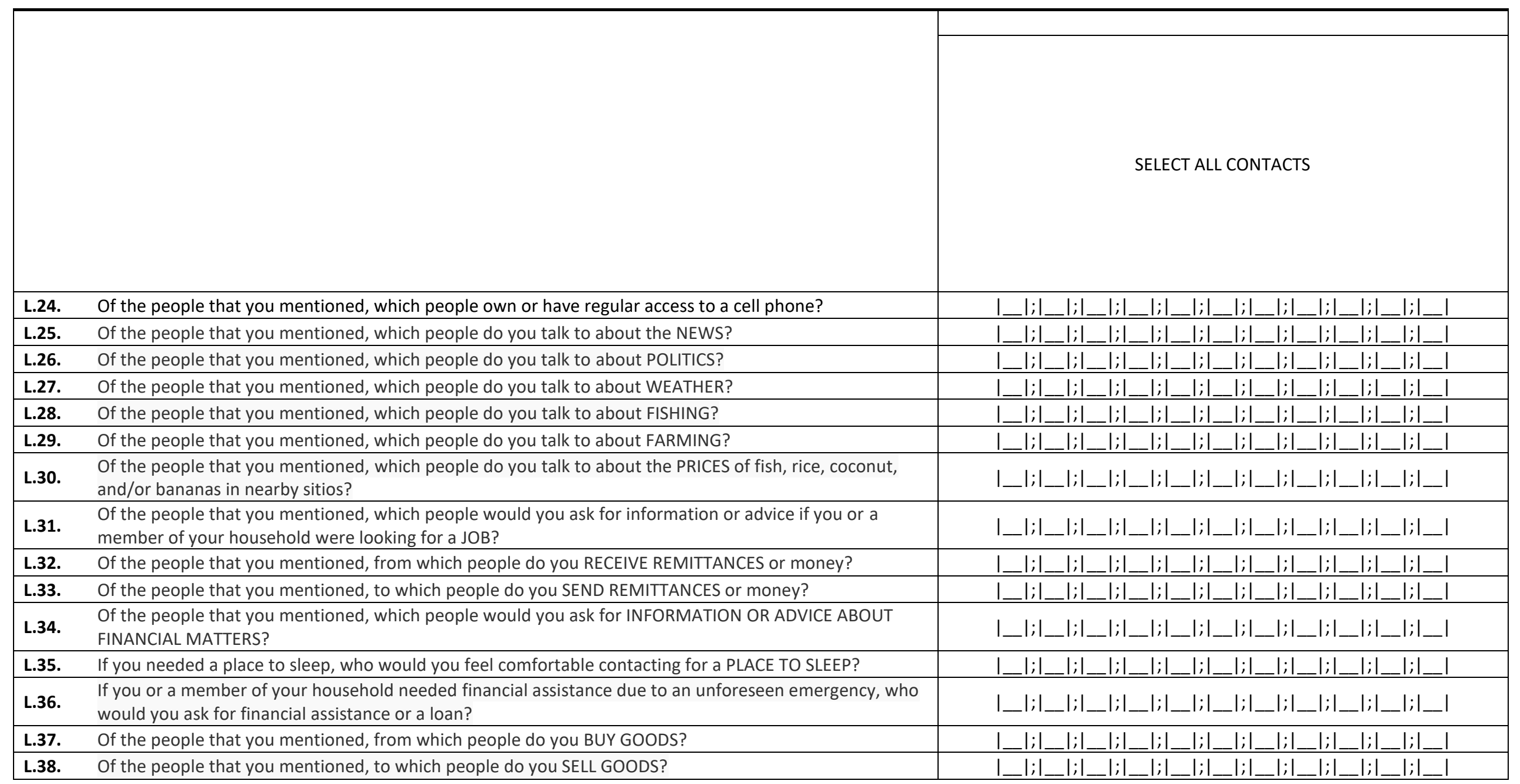


PROJECT SITE I___ I I I I

HHUID I____ I I______ I

SECTION J: Household decision making

\begin{tabular}{|c|c|}
\hline J.1. & J.2. \\
\hline $\begin{array}{c}\text { In your household, who decides what to buy in the } \\
\text { market or what to cook for the family? } \\
\text { SELECT MULTIPLE } \\
\text { HH MEMBER IDs }\end{array}$ & $\begin{array}{l}\text { In your household, who decides when buying expensive things } \\
\text { for the household such as radio, TV, etc.? } \\
\text { SELECT MULTIPLE } \\
\text { HH MEMBER IDs }\end{array}$ \\
\hline |_l;|_l;|_l;|_l & I_l; |_l;|_l;|_| \\
\hline
\end{tabular}

\section{SECTION R: Raven Matrices}

I am going to show you a set of pictures. Please select the missing piece that you think completes the pattern.

\section{Practice:}
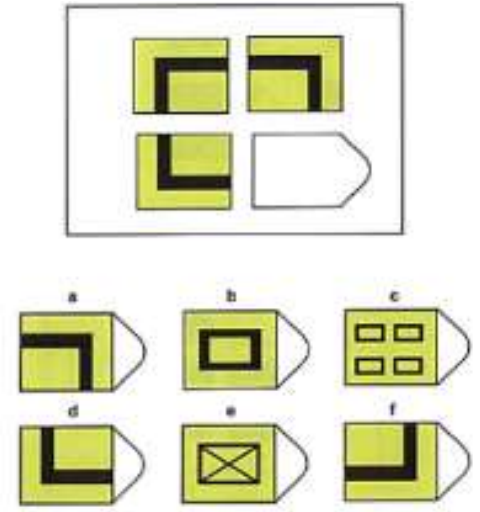

R.3:

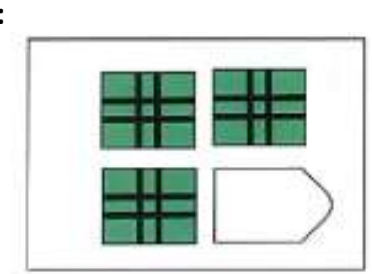

R.4:

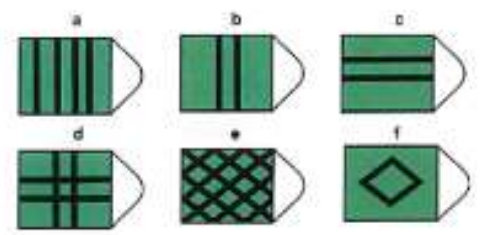

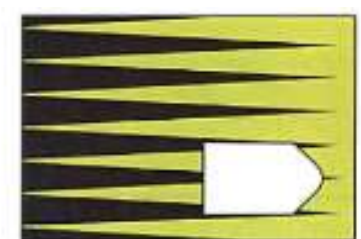

R.5:
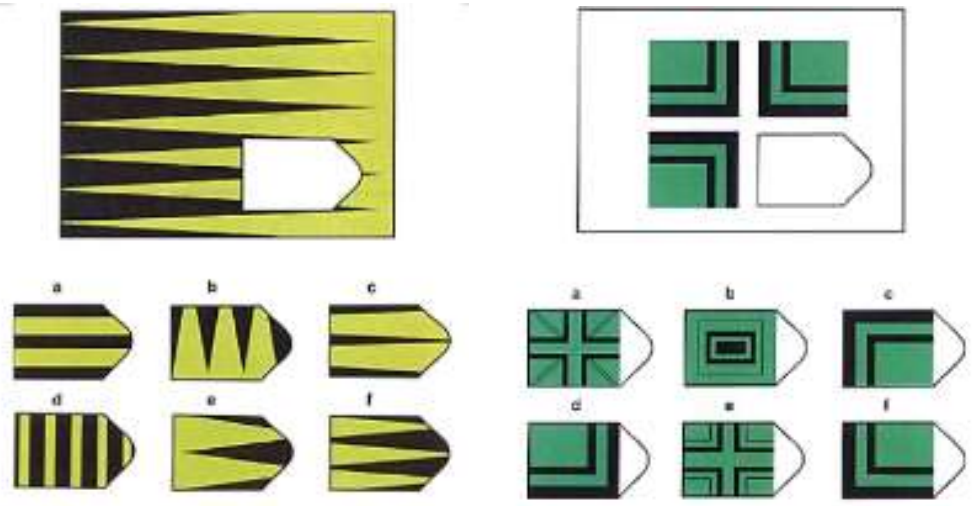

\begin{tabular}{|c|c|c|c|c|c|c|c|c|}
\hline \multicolumn{3}{|c|}{ R.1. } & \multicolumn{3}{|c|}{ R.2. } & \multicolumn{3}{|c|}{ R.3. } \\
\hline 1 - Piece $A$ & 3 - Piece C & 5 - Piece $\mathrm{E}$ & 1 - Piece $A$ & 3 - Piece $C$ & 5-Piece E & 1 - Piece $\mathrm{A}$ & 3 - Piece C & 5-Piece $E$ \\
\hline 2-Piece B & 4-Piece D & 6 - Piece $\mathrm{F}$ & 2 - Piece $B$ & 4-Piece & 6 - Piece F & 2-Piece $B$ & 4-Piece D & 6 - Piece $F$ \\
\hline \multicolumn{3}{|c|}{ I_l } & \multicolumn{3}{|c|}{ I_l } & \multicolumn{3}{|c|}{$I_{-}$} \\
\hline
\end{tabular}

CCN Baseline Survey - Page 13 of 16 - Version: 2016-07-20 
PROJECT SITE I______ I

SECTION I: Information sources

\begin{tabular}{|c|c|c|}
\hline & \multicolumn{2}{|c|}{ I.1. } \\
\hline & \multicolumn{2}{|c|}{$\begin{array}{l}\text { People learn what is going on in the Philippines and the world from various } \\
\text { sources. For each of the following sources, please indicate whether you use it to } \\
\text { obtain information } \\
\text { (1) daily } \\
\text { (2) weekly } \\
\text { (3) monthly } \\
\text { (4) less than monthly } \\
\text { (5) never. }\end{array}$} \\
\hline (i) Daily newspaper or printed magazines & \multicolumn{2}{|c|}{$I_{\ldots}$} \\
\hline (ii) TV news & \multicolumn{2}{|c|}{$I_{-} I_{1}$} \\
\hline (iii) Radio news & \multicolumn{2}{|c|}{$I_{-} I_{1}$} \\
\hline (iv) Mobile phone & \multicolumn{2}{|c|}{$I_{-} \mathrm{I}$} \\
\hline (v) Email & \multicolumn{2}{|c|}{$I_{\ldots} I_{1}$} \\
\hline (vi) Facebook, Twitter, or other social media & \multicolumn{2}{|c|}{$I_{-} I$} \\
\hline (vii) Talk with friends and colleagues & \multicolumn{2}{|c|}{$I_{-} I_{1}$} \\
\hline 1.2. Do you see yourself as part of your local community? & $\mathrm{I}$ & \multirow{4}{*}{$\begin{array}{l}1 \text { Definitely } \\
2 \text { Perhaps } \\
3 \text { Neutral } \\
4 \text { Perhaps not } \\
5 \text { Definitely not } \\
-88 \text { Refused } \\
-77 \text { Don't Know/Uncertain }\end{array}$} \\
\hline 1.3. Do you feel isolated from the rest of your country? & $\mathrm{I}$ & \\
\hline $\begin{array}{l}\text { I.4. Do you receive a fair price for the coconuts, fish, and } \\
\text { other products that you sell? }\end{array}$ & $\mathrm{I}$ & \\
\hline $\begin{array}{l}\text { I.5. In case of an emergency, do you feel you would be } \\
\text { able to communicate with family members outside of } \\
\text { this sitio? }\end{array}$ & I_ I & \\
\hline
\end{tabular}




\section{SECTION N: Numeracy}

Now I would like to ask you some questions about numbers. This is not a test and your answers to these questions will not affect anything in the future.

\begin{tabular}{|c|c|c|c|}
\hline N.1. & N.2. & N.3. & N.4. \\
\hline $\begin{array}{l}\text { If you have } 21 \text { rocks } \\
\text { and you add } 36 \text { rocks, } \\
\text { how many rocks do } \\
\text { you have? }\end{array}$ & $\begin{array}{l}\text { If you have } 16 \text { rocks } \\
\text { and take away } 9 \text {, how } \\
\text { many rocks do you } \\
\text { have? }\end{array}$ & If you get 50 Pesos a day for 12 days, what would be the total money you get at the end? & $\begin{array}{l}\text { If someone lends you } 500 \\
\text { Pesos for one month with } 10 \\
\text { percent interest, at the end of } \\
\text { the month how much do you } \\
\text { need to pay back in total? }\end{array}$ \\
\hline $\mathrm{I}$ & $\mathrm{I}$ & $I_{1}$ & I__ I \\
\hline
\end{tabular}

\section{SECTION M: Politics}

I would like to ask you about your experience in recent political elections.

\begin{tabular}{|c|c|c|c|c|c|}
\hline M.1. & M.2. & M.3. & M.4. & M.5. & M.6. \\
\hline $\begin{array}{l}\text { How frequently } \\
\text { do you speak } \\
\text { with the } \\
\text { barangay } \\
\text { captain or } \\
\text { other local } \\
\text { leaders? } \\
1 \text { Often } \\
2 \text { Sometimes } \\
3 \text { Rarely } \\
4 \text { Never }\end{array}$ & $\begin{array}{l}\text { Did you vote in } \\
\text { the } 2016 \\
\text { election? } \\
0 \text { No } \\
1 \text { Yes }\end{array}$ & $\begin{array}{l}\text { Here are some things that can happen to people during election day. } \\
\text { How many of these things happened to you? (You don't have to tell us } \\
\text { which things happened, just how many.) } \\
\text { You went to the voting booth with a friend. } \\
\text { You had a hard time locating your name on the precinct list. } \\
\text { Someone tried to give you money or gifts in exchange for your vote. [included with } \\
0.5 \text { probability] } \\
\text { Your polling officer was a man. } \\
\text { How many did you experience? }\end{array}$ & $\begin{array}{l}\text { Do you think your } \\
\text { barangay captain knows } \\
\text { how you voted? } \\
1 \text { Yes } \\
2 \text { Probably } \\
3 \text { Probably Not } \\
4 \text { No }\end{array}$ & $\begin{array}{l}\text { How comfortable are you } \\
\text { with others having access } \\
\text { to your personal } \\
\text { communication including } \\
\text { conversations by phone } \\
\text { and/or in writing? } \\
1 \text { Very comfortable } \\
2 \text { Somewhat comfortable } \\
3 \text { Neither comfortable } \\
\text { nor uncomfortable } \\
4 \text { Somewhat } \\
\text { uncomfortable } \\
5 \text { Very uncomfortable }\end{array}$ & $\begin{array}{l}\text { Generally speaking, } \\
\text { would you say that most } \\
\text { people can be trusted, or } \\
\text { that you can't be too } \\
\text { careful in dealing with } \\
\text { people? } \\
1 \text { Most people can be } \\
\text { trusted } \\
2 \text { Can't be too careful }\end{array}$ \\
\hline I_I & $I$ & I_I & I_I & & \\
\hline
\end{tabular}

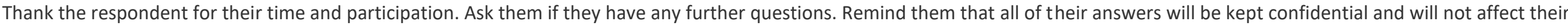
participation, either in the present or in the future, with any program or NGO. 
Y.4.

On a scale of 1 (poorest) to 10 (wealthiest), how wealthy do you think the respondent's household is in comparison with other households in

[barangay_name]?

1 Salvaged/makeshift materials, mixed but predominantly salvaged materials, light materials (cogon,

nipa, anahaw), or mixed but

predominantly light materials

2 Mixed but predominantly strong

materials

3 Strong materials (galvanized iron,

aluminum, tile, concrete, brick, stone,

wood, plywood, asbestos)

Other (Specify)

What is the primary material used for

the dwelling's roof?

1 Thatch/Grass

2 Palm leaf

3 Wood

4 Metal/Tin

5 Plastic

Other (Specify)
Y.3.

dwelling's floor?

1 Dirt/Mud

2 Tiles

3 Cement

4 Plastic

5 Wood

Other (Specify)

\begin{tabular}{|c|c|c|c|}
\hline I_I & I_I & $I \ldots I$ & I_I_I_I \\
\hline
\end{tabular}

Standing near the entrance to the respondent's dwelling, record the GPS coordinates. Wait until the accuracy is below $5 \mathrm{~m}$.

\begin{tabular}{|c|c|c|}
\hline Y.5. & Latitude & 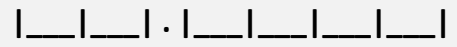 \\
\hline Y.6. & Longitude & I_I_I I_I_I_I_I_I \\
\hline Y.7. & Altitude & 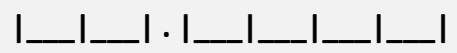 \\
\hline Y.8. & Accuracy & I_I_I_I_I \\
\hline
\end{tabular}

\section{END OF THE SURVEY}




\subsection{Endline Household and Adult Survey}




\section{INNOVATIONS FOR POVERTY ACTION}

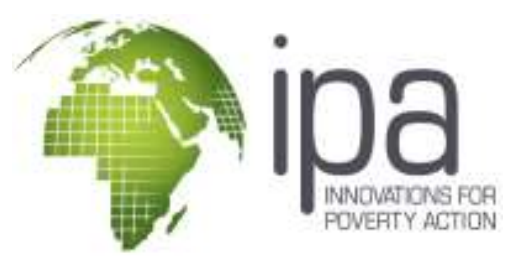

\section{CONNECTING ISOLATED COMMUNITIES 2019 - ENDLINE SURVEY}

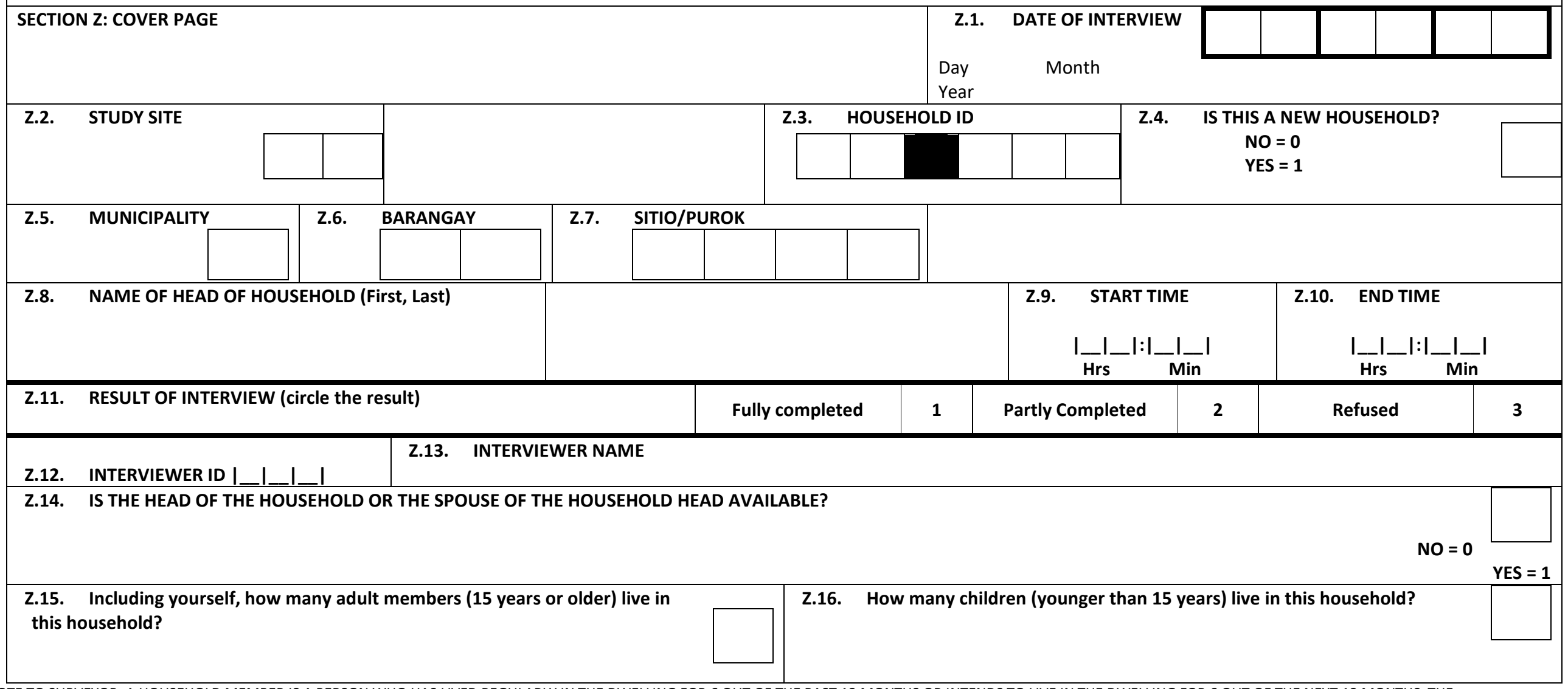




\section{SECTION A. HOUSEHOLD LISTING AND DEMOGRAPHIC INFORMATION}

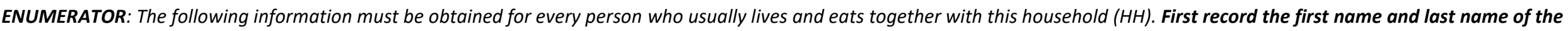

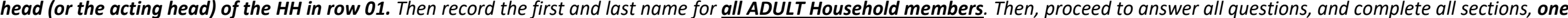
person at a time, following the instructions and skips. If an individual adult is available, each person should answer the questions related to him/her.

\begin{tabular}{|c|c|c|c|c|c|c|c|c|c|c|c|c|}
\hline & A.1. & A.2. & A.3. & A.4. & A.5. & A.6. & A.7. & A.8. & A.9. & A.10. & A.11. & A.12. \\
\hline 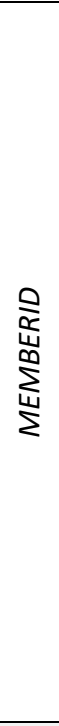 & $\begin{array}{l}\text { FIRST } \\
\text { NAME }\end{array}$ & $\begin{array}{l}\text { LAST } \\
\text { NAME }\end{array}$ & 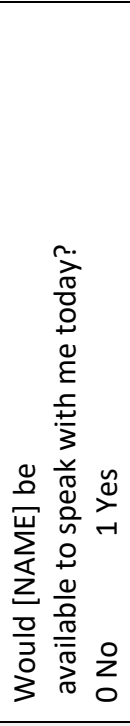 & 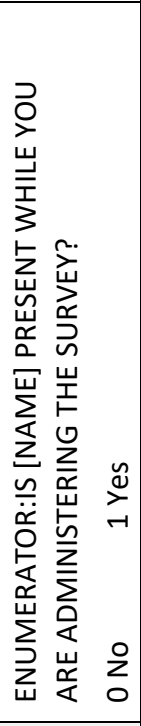 & 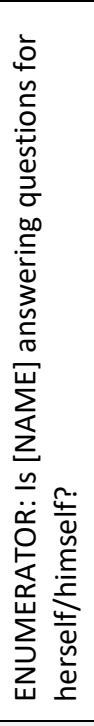 & $\begin{array}{l}\text { Is [NAME] } \\
\text { currently a } \\
\text { member of } \\
\text { this } \\
\text { household } \\
? \\
0 \text { No } \\
1 \text { Yes } \\
\text { >>A.13 }\end{array}$ & $\begin{array}{l}\text { Does [NAME] usually live } \\
\text { here in this dwelling? } \\
\text { Usually means that an } \\
\text { individual ate meals out of } \\
\text { the same pot of food as } \\
\text { the household at least } 4 \text { of } \\
\text { the last } 7 \text { days and slept in } \\
\text { the dwelling at least } 4 \text { of } \\
\text { the last } 7 \\
\text { nights. If the previous } \\
\text { week was not a typical } \\
\text { week, ask this question } \\
\text { about the last typical } \\
\text { week. } \\
0 \text { No } \\
1 \text { Yes>>A.13 }\end{array}$ & $\begin{array}{l}\text { Why is [NAME] no longer a } \\
\text { member of this household? } \\
1 \text { No longer alive } \\
\text { (deceased) >>A.11 } \\
2 \text { Living in another household } \\
\text { in the same barangay >>A.12 } \\
3 \text { Living in another barangay in } \\
\text { the same province>>A.10 } \\
4 \text { Living elsewhere in the } \\
\text { Philippines } \\
5 \text { Living outside of the } \\
\text { Philippines >>A.12 }\end{array}$ & $\begin{array}{l}\text { What } \\
\text { province } \\
\text { does } \\
\text { [NAME] } \\
\text { live in? } \\
\text { See } \\
\text { province } \\
\text { codes. } \\
\text { >>A.12 }\end{array}$ & $\begin{array}{l}\text { What } \\
\text { municipality } \\
\text { does } \\
\text { [NAME] live } \\
\text { in? } \\
1 \text { Baler } \\
2 \text { Casiguran } \\
3 \text { Dilasag } \\
4 \\
\text { Dinalungan } \\
5 \text { Dingalan } \\
6 \text { Dipaculao } \\
7 \text { Maria } \\
\text { Aurora } \\
8 \text { San Luis } \\
\text { Other } \\
\text { >>A.12 }\end{array}$ & $\begin{array}{l}\text { When did } \\
\text { [NAME] } \\
\text { die? }\end{array}$ & $\begin{array}{l}\text { When did } \\
\text { [NAME] } \\
\text { leave this } \\
\text { household } \\
\text { ? } \\
\text { DATE } \\
\text { MM/YYYY }\end{array}$ \\
\hline 01 & & & 1 & I_ I & I_I & I_ & & I_I_I I & I__ I_ I & I_I_I & & \\
\hline 02 & & & I_I & I_I & I_I & I_ I & 1 & I___l_ & I___ I__ & 1 & & \\
\hline 03 & & & 1 & I__ I & I_I & 1 & 1 & I____ I & I___ I I & 1 & & \\
\hline 04 & & & $I \ldots$ & I__ & I_I & $I \ldots$ & $I \ldots$ & I_I_I_ & I_____ & $1 \ldots$ & & \\
\hline 05 & & & 1 & I_ & I_I & 1 & 1 & 1 & I__ I_ I & 1 & & \\
\hline 06 & & & 1 & I__ & I_I & 1 & I_ I & I___l_l & I___ I I & 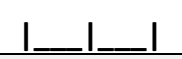 & & \\
\hline 07 & & & 1 & I__ & I_I & 1 & 1 & I______ & I___ I I & 1 & & \\
\hline 08 & & & I_I & I_I & I_I & 1 & 1 & I__ I_I & $I_{\ldots} I_{\ldots}$ & $I_{\ldots} I_{\ldots} \mid$ & & \\
\hline 09 & & & I_I & I_I & I_I & 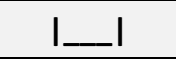 & $I$ & I__ I_I & I_____ I & 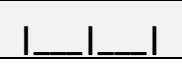 & & \\
\hline 10 & & & 1 & 1 & I_I & 1 & 1 & 1 & 1 & 1 & & \\
\hline 11 & & & 1 & 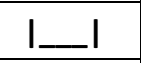 & I_I & 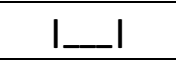 & 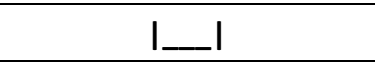 & I__ I I I & $I_{\ldots} I_{\ldots}$ & 1 & & \\
\hline
\end{tabular}


PROJECT SITE I______ I

HHUID I 1

\begin{tabular}{|c|c|c|c|c|c|c|c|c|c|}
\hline & A.13. & A.14. & A.15. & A.16. & A.17. & A.18. & A.19. & A.20. & A.21. \\
\hline 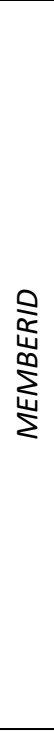 & $\begin{array}{l}\text { What is the } \\
\text { nickname of } \\
\text { [NAME]? } \\
\text { [Prefilled } \\
\text { Update if necessary] }\end{array}$ & $\begin{array}{l}\text { Is [NAME] } \\
\text { male or } \\
\text { female? }\end{array}$ & \begin{tabular}{|l|} 
What is \\
[NAME]'s \\
age? \\
(Age in year \\
at last \\
birthday) \\
[Prefilled \\
Update if \\
necessary]
\end{tabular} & $\begin{array}{l}\text { Relationship to the head } \\
\text { of household } \\
1 \text { Head of Household } \\
2 \text { Wife or husband } \\
3 \text { Son or daughter } \\
4 \text { Son-/daughter-in-law } \\
5 \text { Grandchild } \\
6 \text { Father or Mother } \\
7 \text { Nephew or Niece } \\
8 \text { Brother or sister } \\
9 \text { Brother-/sister-in-law } \\
10 \text { Other relative } \\
11 \text { Unrelated member } \\
-88 \text { Refused } \\
-77 \text { Don't know } \\
\text { [Prefilled } \\
\text { Update if necessary] }\end{array}$ & $\begin{array}{l}\text { What is the highest grade level } \\
\text { completed by [NAME]? } \\
\text { No formal schooling } \\
1 \text { Some elementary (did not } \\
\text { graduate/complete } \\
\text { elementary) } \\
2 \text { Elementary graduate } \\
3 \text { Some high school (did not } \\
\text { graduate/complete high } \\
\text { school) } \\
4 \text { High school graduate } \\
5 \text { Vocational training } \\
6 \text { Some college or higher } \\
7 \text { College graduate } \\
-88 \text { Refused } \\
-77 \text { Don't Know/Uncertain } \\
\text { [Prefilled } \\
\text { Update if necessary] }\end{array}$ & $\begin{array}{l}\text { What is } \\
\text { [NAME]'s } \\
\text { current } \\
\text { marital } \\
\text { status? } \\
1 \text { Never } \\
\text { married } \\
2 \text { Married } \\
3 \text { Divorced or } \\
\text { separated } \\
4 \text { Widowed } \\
5 \text { Not married } \\
\text { but living } \\
\text { together }\end{array}$ & $\begin{array}{l}\text { At what } \\
\text { age did } \\
\text { [NAME] } \\
\text { first get } \\
\text { married? }\end{array}$ & $\begin{array}{l}\text { Does } \\
\text { [NAME]'s } \\
\text { spouse live } \\
\text { in this } \\
\text { household? } \\
0 \text { No } \\
1 \text { Yes }\end{array}$ & $\begin{array}{l}\text { Who is the } \\
\text { spouse of } \\
\text { [NAME]? } \\
\text { MEMBERID }\end{array}$ \\
\hline 01 & & $I \ldots$ & I_I_I_I & I_I_I_I & I_I_I_ & 1 & $I_{-} I_{-}$ & $I$ & I__ I_ I \\
\hline 02 & & I_I & I__ I_ I & I_I_I_I & I_I_I_I & I_I & I_I_I_I & I_I & I_I_I_I \\
\hline 03 & & $I$ & I_I_I_I & I_I_I_I & I_I_I_I & I_I & I_I_I_I & I_I & I_I_I_I \\
\hline 04 & & 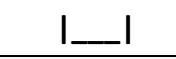 & I_I_I_I_ I & I_I_I_I & I_____ I & 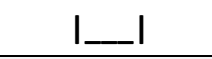 & I___ I_ I & I_ I & I__ I_ I_ \\
\hline 05 & & 1 & I_I_I_I & I_I_I_I & I__ I_ I & I_ I & I__ I_ I & I_ I & I__ I_ I \\
\hline 06 & & $I \ldots$ & I_I_I_I_ & I_I_I_I & I_I_I_I & I_ I & I__ I_ I & $I$ & I__ I_ I__ \\
\hline 07 & & 1 & I_I_I_ I & I_I_I_I & I_I_I_ & I_I & I_I_I I I & 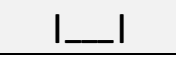 & I_ I_ I_ \\
\hline 08 & & $I \ldots$ & I_I_I_ & I_I_I_I_I & I_I_I_I_ & $I \ldots$ & I_I_I_I & I_ I & I__ I_ I_ \\
\hline 09 & & 1 & I_I_I_I_ & I_I_I_I_ & I_I_I_I & 1 & I___ I_ & I_ I & I_ I_ I__ \\
\hline 10 & & 1 & I_I_I_I & I_I_I_I_I & I_I_I_I & I_I & I_I_I_I & I__ & I_I_I_ I_ \\
\hline 11 & & 1 & I_I_I_ I & I_I_I_ I & I_____ I & 1 & I__ I_ I & 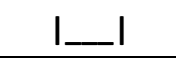 & I__ I_ I \\
\hline 12 & & 1 & I_I_I_I_ & I_I_I_I_ & I_I_I_I_ & 1 & I_I_I_I & I_ I & I_I_I_ I_ \\
\hline
\end{tabular}




\begin{tabular}{|c|c|c|c|c|c|c|c|c|c|c|}
\hline & A.22. & A.23. & A.24. & A.25. & A.26. & A.27. & A.28. & A.29. & A.30. & A.31. \\
\hline \multirow[b]{2}{*}{ 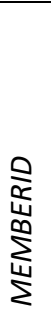 } & \multirow{2}{*}{$\begin{array}{l}\text { For how many months in } \\
\text { total during the last } 12 \\
\text { months has [NAME] been } \\
\text { present in this household? }\end{array}$} & \multirow{2}{*}{$\begin{array}{l}\text { During the last } 12 \\
\text { months, approximately } \\
\text { how many separate } \\
\text { times did [NAME] leave } \\
\text { the barangay for more } \\
\text { than one week? }\end{array}$} & \multirow{2}{*}{$\begin{array}{l}\text { During the last } 12 \text { months ( } 52 \text { weeks), } \\
\text { how many complete weeks did [NAME] } \\
\text { spend away from this dwelling? }\end{array}$} & \multicolumn{7}{|c|}{ Of the weeks that [NAME] was away, how many weeks were spent... } \\
\hline & & & & $\begin{array}{l}\text { in school or } \\
\text { for other } \\
\text { education } \\
\text { reasons? }\end{array}$ & $\begin{array}{l}\text { visiting } \\
\text { friends and } \\
\text { family? }\end{array}$ & $\begin{array}{l}\text { working in } \\
\text { construction? }\end{array}$ & $\begin{array}{l}\text { working in } \\
\text { agriculture } \\
\text { or farming? }\end{array}$ & $\begin{array}{l}\text { working in } \\
\text { the fishing } \\
\text { industry? }\end{array}$ & $\begin{array}{l}\text { working in } \\
\text { other jobs (not } \\
\text { in } \\
\text { construction, } \\
\text { agriculture, or } \\
\text { fishing)? }\end{array}$ & $\begin{array}{l}\text { looking for } \\
\text { work? }\end{array}$ \\
\hline 01 & $\mathrm{I}$ & $\mathrm{I}$ & I_____ & I___l_ I & I___ I I & I____l I & I_L_I & 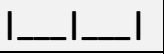 & I_____ I & I_I_I I I \\
\hline 02 & 1 & I__ & I_I_I_I_ & I______ I_ & I___ا_I_ & I__ I_ I & I_L_ا_ & I_I_I_ I & I______ I_ & I_I_I_I_ \\
\hline 03 & 1 & I__ & I_I_I & I_I_I & I___ I_L_ & I__ I_ I & I___ & $I$ & I___ I__ & I___ I__ \\
\hline 04 & $\mathrm{I}$ & $\mathrm{I}$ & I_____ I & I___ I I & $I \ldots$ & I___l_l & I___L I & $\mathrm{I}$ & I_____ I & I___l_ I \\
\hline 05 & I_I & I_I & I_I_I_I & I_I_I_I & I_I_I_I & I_I_I_I & I_I_I & I_I_I & I_I_I_I & I_I_I_I_L \\
\hline 06 & $\mathrm{I}$ & 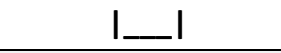 & I_I_ا_I_I & I___ I_ & I_L_ا_I & I___ I_ I & I_I_I & 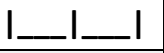 & I_____ & I_I_I_I \\
\hline 07 & 1 & 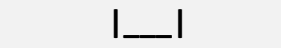 & I_I_I_I_ & I_I_I_I & I_____ I & I_I_I_I I & I_I_I_I & I_I_I & I_______ & I_I_I_I_ \\
\hline 08 & 1 & I__ I & I_I_ا_I_L_ & I_I_I_I_L_ & I_I_I_I I & I_I_I_I I & I_I_I_I & I_I_I_ & I_ا_ا_ا & I_I_ا_I_ا_ \\
\hline 09 & 1 & I__ & I_I_I_I_L_ & I_____ I_ & I_____ I_ & I_I_I_I I & I_L_I_ & I_I_I & I___ا_I_L_ & I___ا_I__ \\
\hline 10 & 1 & $I \ldots I$ & I___ I__ & I_I_I_L_ & I_I_I_L_ & I____ I I & I_I_I_L & I_I_I & I________ & I_I_I_I_ \\
\hline 11 & 1 & I_I & I_I_I_ & I_I_I & I___ I_ & 1 & I_I_I & 1 & I_____ & I_I_I_I_ \\
\hline 12 & 1 & $I \ldots I$ & I_I_ا_I_L_ & I___ا_I_L_ & 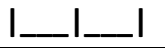 & I_____ I & I_I_I_L & I_I_I I & I___ا_I_L_ا & I_I_ا_I_L_ا_ \\
\hline
\end{tabular}




\begin{tabular}{|c|c|c|c|c|c|c|c|c|c|}
\hline \multirow{3}{*}{ 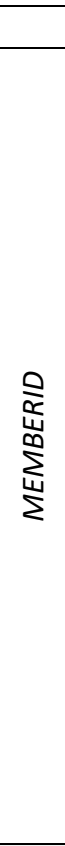 } & \multirow{3}{*}{$\begin{array}{l}\text { A.32. } \\
\text { The last time [NAME] was away } \\
\text { from the barangay, how much did } \\
\text { he/she earn in total wages, } \\
\text { benefits, self-employment profits, } \\
\text { or other income sources? } \\
\text { PESOS } \\
\text { Include compensation only and not } \\
\text { remittances, gifts, or loans. Exclude } \\
\text { income from crop and fish sales, } \\
\text { but include any wages earned from } \\
\text { these activities. }\end{array}$} & \multirow{2}{*}{\multicolumn{2}{|c|}{\begin{tabular}{l}
\multicolumn{1}{c}{ A.33. } \\
What length of time \\
did this income \\
correspond to?
\end{tabular}}} & \multirow{3}{*}{\begin{tabular}{|l}
\multicolumn{1}{|c|}{ A.34. } \\
During the weeks \\
that [NAME] was \\
away from the \\
barangay over the \\
past 12 months, \\
how much did \\
[NAME] send in \\
remittances to \\
members of the \\
household?
\end{tabular}} & \multirow{3}{*}{\begin{tabular}{l}
\multicolumn{1}{c}{ A.35. } \\
When \\
[NAME] sent \\
remittances \\
over the \\
weeks away, \\
to which \\
household \\
member(s) \\
did [NAME] \\
send \\
remittances?
\end{tabular}} & \multirow[b]{2}{*}{\begin{tabular}{l}
\multicolumn{1}{c}{ A.36. } \\
The last time that \\
[NAME] sent a \\
remittance to \\
someone in the \\
household, how was \\
the money received?
\end{tabular}} & \multirow{2}{*}{\begin{tabular}{l}
\multicolumn{1}{c|}{ A.37. } \\
During the last 12 \\
months, which places \\
did [NAME] travel to \\
outside this barangay?
\end{tabular}} & \multirow{2}{*}{\begin{tabular}{l}
\multicolumn{1}{c}{ A.38. } \\
When [NAME] \\
is away from \\
the barangay, \\
how frequently \\
do they \\
communicate \\
with members \\
of the \\
household here \\
in the \\
barangay?
\end{tabular}} & \multirow{2}{*}{\begin{tabular}{l}
\multicolumn{1}{c}{ A.39. } \\
When [NAME] is away from \\
the barangay, how does \\
he/she generally communicate \\
with members of the \\
household here in the \\
barangay?
\end{tabular}} \\
\hline & & & & & & & & & \\
\hline & & $\#$ & $\begin{array}{l}\text { Unit } \\
1 \text { hours } \\
2 \text { days } \\
3 \\
\text { weeks } \\
4 \\
\text { months } \\
5 \text { years }\end{array}$ & & & $\begin{array}{l}1 \text { In person in your } \\
\text { sitio/purok } \\
2 \text { In person in Baler } \\
3 \text { In person in } \\
\text { Dingalan } \\
4 \text { In person } \\
\text { elsewhere } \\
5 \text { Via Western Union, } \\
\text { Cebuana Lhuiller, or } \\
\text { other money transfer } \\
\text { platform } \\
\text { Other (specify) }\end{array}$ & $\begin{array}{l}3 \text { Another barangay } \\
\text { in the same } \\
\text { province } \\
4 \text { Elsewhere in the } \\
\text { Philippines } \\
5 \text { Outside of the } \\
\text { Philippines } \\
\text { Other (Specify) }\end{array}$ & $\begin{array}{l}\text { of the } \\
\text { household here } \\
\text { in the } \\
\text { barangay? } \\
1 \text { Daily } \\
2 \text { Weekly } \\
3 \text { Monthly } \\
4 \text { Less than } \\
\text { once a } \\
\text { month } \\
5 \text { Never }\end{array}$ & $\begin{array}{l}\text { SELECT MULTIPLE } \\
1 \text { Phone calls on a phone } \\
2 \text { Text messages on a } \\
\text { phone } \\
3 \text { Email on a phone } \\
4 \text { Other messaging service } \\
\text { on a phone } \\
5 \text { Facebook } \\
6 \text { Other social media } \\
7 \text { Mail } \\
8 \text { Person-to-person }\end{array}$ \\
\hline 01 & 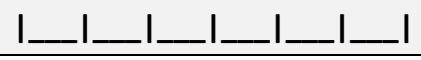 & $I \ldots I$ & I__ I & I_I_I_I_I_I_L_ & 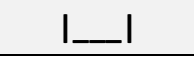 & $I \ldots I$ & $I \ldots$ & 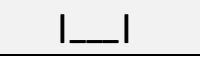 & $I \ldots I$ \\
\hline 02 & 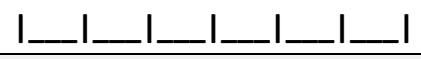 & $I \ldots I$ & $\mathrm{I}$ & I__ I________ I & $I_{-} I$ & $\mathrm{I}$ & $\mathrm{I}$ & $\mathrm{I}$ & I_I_I \\
\hline 03 & 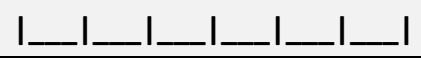 & 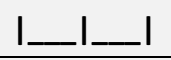 & $I_{-} I_{1}$ & $I_{-} I_{-} I_{-} I_{-} I$ & $I_{-} I$ & $\mathrm{I}$ & $\mathrm{I}$ & $\mathrm{I}$ & $I_{-} I_{-} I$ \\
\hline 04 & 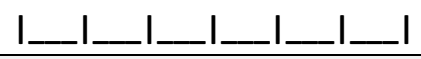 & $I \_I \_I$ & $\mathrm{I}$ & 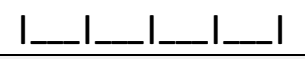 & $I_{-} I$ & $\mathrm{I}$ & $\mathrm{I}$ & $\mathrm{I}$ & I___ I \\
\hline 05 & 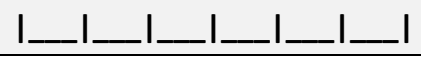 & $I \ldots I$ & $\mathrm{I}$ & I__ I__ I___ I I & $I_{-} I$ & $\mathrm{I}$ & $I_{-} I$ & $\mathrm{I}$ & 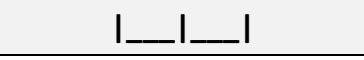 \\
\hline 06 & 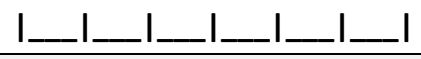 & I_I_I & I__ I & 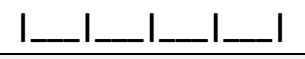 & I_ I & $\mathrm{I}$ & $\mathrm{I}$ & $\mathrm{I}$ & I_I_ I_ \\
\hline 07 & 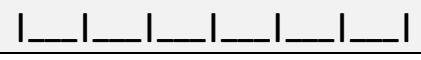 & $I \ldots I$ & $\mathrm{I}$ & I__________ I & $\mathrm{I}$ & $\mathrm{I}$ & $I_{-} I$ & $\mathrm{I}$ & I___ I_ \\
\hline 08 & 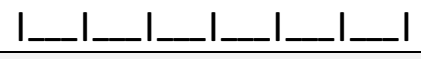 & $I \ldots I \ldots I$ & $\mathrm{I}$ & 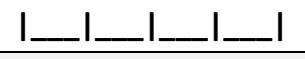 & $\mathrm{I}$ & $\mathrm{I}$ & $\mathrm{I}$ & $\mathrm{I}$ & I___ I_ \\
\hline 09 & 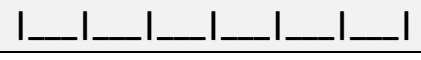 & $I \ldots I \ldots I$ & $\mathrm{I}$ & 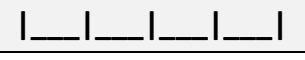 & $\mathrm{I}$ & $\mathrm{I}$ & $\mathrm{I}$ & $\mathrm{I}$ & I___ I_ \\
\hline 10 & 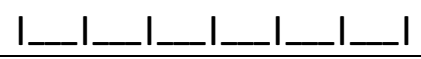 & 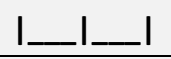 & $I_{-} \mathrm{I}$ & 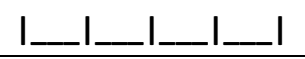 & $\mathrm{I}$ & 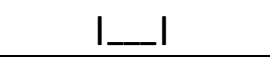 & 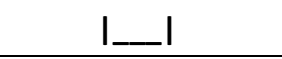 & 1 & I_I_I_I \\
\hline
\end{tabular}




\begin{tabular}{|c|c|c|c|c|c|}
\hline \multicolumn{2}{|c|}{ PROJECT SITE I_____ } & \multirow[b]{2}{*}{ A.41. } & \multirow[b]{2}{*}{ A.42. } & \multicolumn{2}{|r|}{ HHUID I__ I__ I I__ I__ I I I I } \\
\hline & A.40. & & & A.43. & A.44. \\
\hline 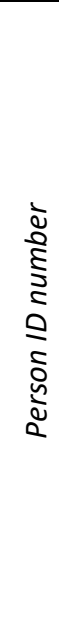 & $\begin{array}{l}\text { In the last completed week, } \\
\text { what was [NAME]'s primary } \\
\text { occupation? } \\
\text { O Did not work/stayed at home } \\
1 \text { Farming } \\
2 \text { Fishing } \\
3 \text { Construction, road } \\
\text { maintenance } \\
4 \text { Logging } \\
5 \text { Professional work (i.e. } \\
\text { teacher, government job, etc.) } \\
6 \text { Student } \\
7 \text { Other work for a wage, salary, } \\
\text { commission in cash, or in-kind } \\
8 \text { Self-employment, any non-farm } \\
\text { business, by oneself or with a few } \\
\text { partners to earn income }\end{array}$ & $\begin{array}{l}\text { Location of work } \\
1 \text { In the same sitio/barangay } \\
2 \text { In neighboring barangay } \\
3 \text { In Baler } \\
4 \text { In Dingalan } \\
5 \text { In Manila } \\
\text { Other (Specify) }\end{array}$ & $\begin{array}{l}\text { Over the past } 30 \text { days, how much } \\
\text { total income did [NAME] earn in } \\
\text { wages, benefits, self-employment } \\
\text { profits, or other income sources? } \\
\text { PESOS } \\
\text { Include compensation only and } \\
\text { not remittances, gifts, or loans. } \\
\text { Exclude income from crop and fish } \\
\text { sales, but include any wages } \\
\text { earned from these activities. }\end{array}$ & $\begin{array}{l}\text { Does [NAME] plan to travel outside of the barangay } \\
\text { for any reason in the next } 12 \text { months? }\end{array}$ & $\begin{array}{l}\text { What are the reasons [NAME] would travel in the } \\
\text { next } 12 \text { months? } \\
\text { SELECT MULTIPLE } \\
1 \text { For work (permanent, } 3 \text { months or longer) } \\
2 \text { For work (temporary, less than } 3 \text { months) } \\
3 \text { For school } \\
4 \text { To socialize with friends, family, or others } \\
5 \text { To sell goods } \\
6 \text { To buy agricultural inputs } \\
7 \text { To shop for general household shopping } \\
8 \text { For a financial transaction (at the bank or } \\
\text { to make/receive a payment) } \\
9 \text { For medical or health reasons } \\
\text { Other (Specify) }\end{array}$ \\
\hline 02 & $I_{-} I$ & $\mathrm{I}$ & 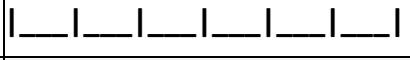 & $I_{-}$ & I__lil__lil__lil__lil__ \\
\hline 03 & $I_{-} I$ & $I_{-} I$ & 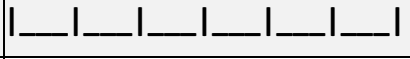 & $I \ldots$ & I__lil_lil__lil__lil_l \\
\hline 04 & $I_{-} I$ & $\mathrm{I}$ & 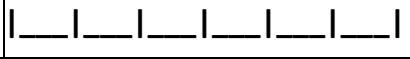 & $I_{-} I$ & I_lil_lil__lil_lil_l \\
\hline 05 & $I \ldots$ & $I$ & 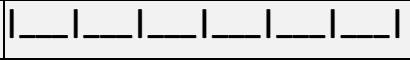 & $I_{-} I$ & I_lil_lil_lil_lil_l \\
\hline 06 & $\mathrm{I}$ & I_I & 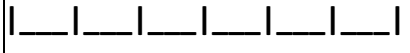 & I_ & I_lil__lil_lil_lil_l \\
\hline 07 & $I_{-} I$ & $\mathrm{I}$ & 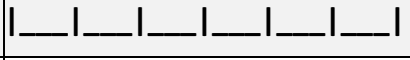 & 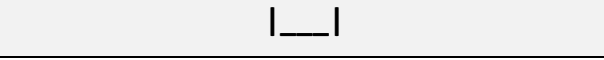 & I__lil__lil__lil__lil__ \\
\hline 08 & $\mathrm{I}$ & $\mathrm{I}$ & 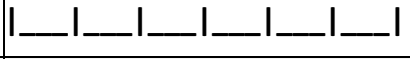 & 1 & 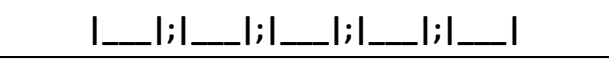 \\
\hline 09 & $I_{-} I$ & $I_{-} I$ & 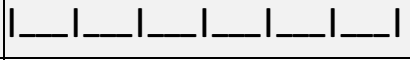 & 1 & 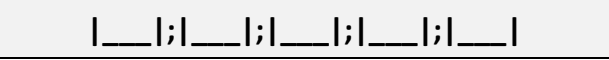 \\
\hline 10 & $\mathrm{I}$ & $I_{-} I$ & 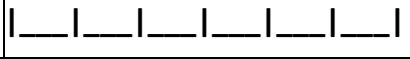 & $I_{-}$ & I_lil__lil_lil__lil_l \\
\hline 11 & $I$ & $\mathrm{I}$ & 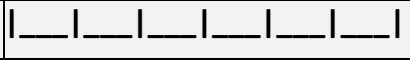 & $I_{-} I$ & I__lil_lil__lil__lil_ \\
\hline 12 & $\mathrm{I}$ & $I_{-} I$ & 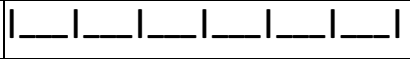 & $I_{-} I$ & I_lil_lil__lil_lil_l \\
\hline
\end{tabular}


PROJECT SITE I___ I__

HHUID | 1

\section{SECTION B. Assets \& Phones}

B.1. How many separate rooms are there in this

household that are currently occupied or could be occupied?

do not count bathrooms, toilets, storerooms and garage)

B.2. Does your household own land that you either live on or use for farming?

B.3. $\quad$ Who in your household owns land that you either live on or use for farming?

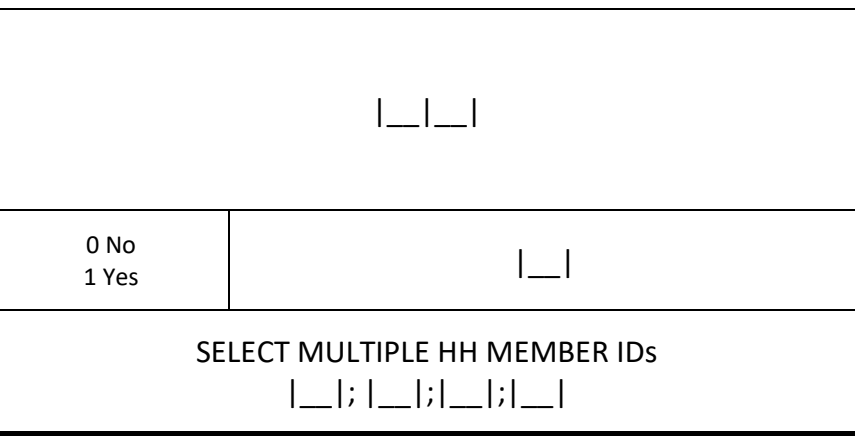

B.4.

Does your household own any of the following?

0 No

1 Yes

\begin{tabular}{rl|}
\hline (i) Sala sets & \\
\hline (ii) Refrigerator/freezer & \\
\hline (iii) Television set & \\
\hline (iv) VTR/VHS/VCD/DVD player & \\
\hline (v) Radio & \\
\hline (vi) Satellite dish & \\
\hline (vii) Motorized vehicle (boat, car, tricycle motorbike) & \\
\hline (viii) Gas stove & I___ \\
\hline
\end{tabular}




\begin{tabular}{|c|c|c|}
\hline B.5. Does your household have access to electricity in this dwelling? & $\begin{array}{l}0 \text { No } \\
1 \text { Yes }\end{array}$ & I_l \\
\hline B.6. Can you make a phone call from this dwelling? & $\begin{array}{l}0 \text { No } \\
1 \text { Yes }\end{array}$ & I_l \\
\hline $\begin{array}{l}\text { B.7. How many minutes would it take you to get to a place where } \\
\text { you could make a phone call using a cellphone? }\end{array}$ & \multicolumn{2}{|c|}{ I_l_l_l } \\
\hline B.8. How many cell phones does your household own? & \multicolumn{2}{|c|}{ I_I_I } \\
\hline $\begin{array}{l}\text { B.9. How many of these cell phones were obtained after [DATE]? } \\
\text { DATE is the date when the VBTS was launched }\end{array}$ & & \\
\hline $\begin{array}{l}\text { B.10. How many of these cell phones are } 2 \mathrm{G} \text { (i.e. simple feature } \\
\text { phones, non-smartphones)? }\end{array}$ & \multicolumn{2}{|c|}{ I_l_l } \\
\hline B.11. How many of these cell phones are smartphones? & \multicolumn{2}{|c|}{$I_{-} I_{-} \mid$} \\
\hline B.12. Who in your household owns a cell phone? & \multicolumn{2}{|c|}{$\begin{array}{l}\text { SELECT MULTIPLE HH MEMBER IDS } \\
\qquad|\ldots| ;\left|{ }_{-}\right| ;\left.\right|_{\ldots}|;|_{\ldots} \mid\end{array}$} \\
\hline B.13. How many SIM cards does your household own? & \multicolumn{2}{|c|}{$I_{\ldots} I_{-} \mid$} \\
\hline B.14. Which cell phone providers do these SIM cards come from? & \multicolumn{2}{|c|}{$\begin{array}{l}1 \text { Globe } \\
2 \text { Smart } \\
3 \text { Sun } \\
4 \text { Touch Mobile (TM) } \\
5 \text { Talk and Text (TNT) } \\
6 \text { ABS-CBN Mobile } \\
7 \text { VBTS }\end{array}$} \\
\hline B.15. Who in your household owns a SIM card? & \multicolumn{2}{|c|}{ 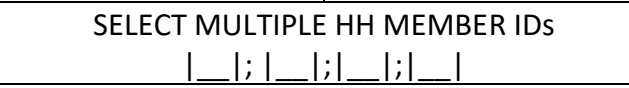 } \\
\hline
\end{tabular}


(i) About how much did your household spend on food in the past 7 days?

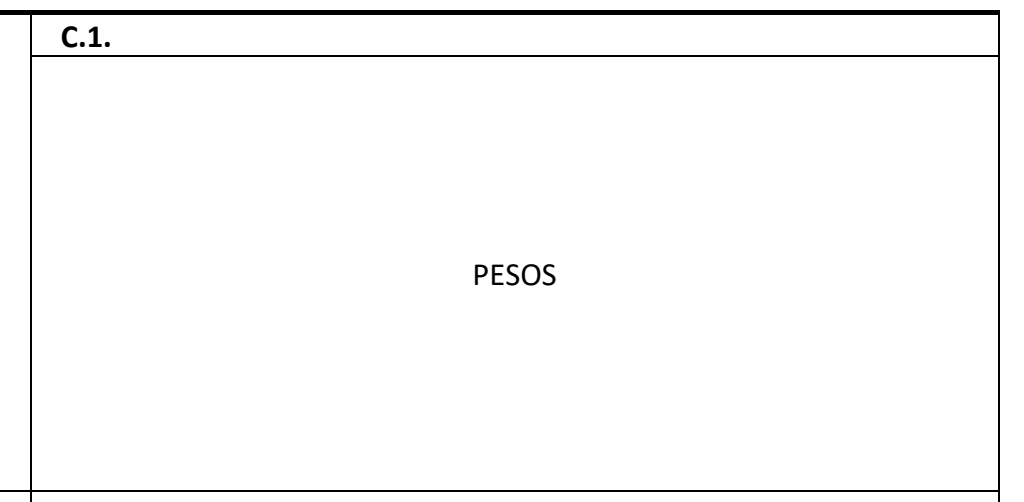

(ii) About how much did your household spend on school expenses, such as school fees, uniforms, books, in

the past 6 months?

(iii) About how much did your household spend on any business, farming, or fishing related work in the past 6

months?

(iv) About how much did your household spend on health expenses in the past 30 days?

(v) About how much did your household spend on power, electricity, or energy in the past 30 days?

(vi) About how much did your household spend on clothing in the past 30 days?

(vii) About how much did your household spend on transport in the past 30 days?

(viii) About how much did your household spend on communications (mail, email, phone purchases, airtime) in the past 30 days?

C.2. Concerning your family's food consumption over the past one month, which of the following is true?

1 Less than adequate

2 Just adequate 3 More than adequate

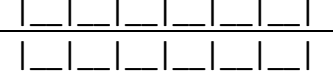

I_ı_ı_ı_ı_ı_

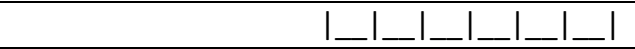

1 $1+1+1-1+1$

I_l_l_l_l_l_l

I_l_l_l_l_o_

I_l_l_l_l_l_l 


\section{SECTION D. Household Income Sources}

\begin{tabular}{|c|c|c|c|c|c|c|c|c|c|}
\hline \multicolumn{2}{|c|}{ D.1. } & D.2. & \multicolumn{2}{|c|}{ D.3. } & \multicolumn{2}{|r|}{ D.4. } & D.5. & \multicolumn{2}{|c|}{ D.6. } \\
\hline $\begin{array}{l}\text { In the } \\
\text { the FIR } \\
\text { source } \\
\text { houser } \\
1 \text { Farm } \\
2 \text { Fishir } \\
3 \text { Logg } \\
4 \text { Othe } \\
5 \text { Othe } \\
6 \text { Remi } \\
\text { from fa } \\
7 \text { Gove } \\
8 \text { Assis } \\
\text { private } \\
-98 \text { No }\end{array}$ & $\begin{array}{l}\text { Tst } 12 \text { months, what is } \\
\text { T most important } \\
\text { f income for your } \\
\text { ld? } \\
\text { wage employment } \\
\text { self employment } \\
\text { tances/Gifts/Donations } \\
\text { nily or friends } \\
\text { nment assistance } \\
\text { ance from religious or } \\
\text { prganization } \\
\text { applicable/none }\end{array}$ & $\begin{array}{l}\text { In the past } 12 \text { months, what was } \\
\text { the estimated income your } \\
\text { household received from the FIRST } \\
\text { most important source of income? }\end{array}$ & \multicolumn{2}{|c|}{$\begin{array}{l}\text { In the past } 12 \text { months, what is } \\
\text { the SECOND most important } \\
\text { source of income for your } \\
\text { household? } \\
1 \text { Farming } \\
2 \text { Fishing } \\
3 \text { Logging } \\
4 \text { Other wage employment } \\
5 \text { Other self employment } \\
6 \text { Remittances/Gifts/Donations } \\
\text { from family or friends } \\
7 \text { Government assistance } \\
8 \text { Assistance from religious or } \\
\text { private organization } \\
-98 \text { Not applicable/none }\end{array}$} & $\begin{array}{l}\text { In the p } \\
\text { the estir } \\
\text { househo } \\
\text { SECOND } \\
\text { income? }\end{array}$ & $\begin{array}{l}12 \text { months, what was } \\
\text { ted income your } \\
\text { received from the } \\
\text { ost important source of }\end{array}$ & $\begin{array}{l}\text { In the past } 12 \text { months, what is } \\
\text { the THIRD most important source } \\
\text { of income for your household? } \\
1 \text { Farming } \\
2 \text { Fishing } \\
3 \text { Logging } \\
4 \text { Other wage employment } \\
5 \text { Other self employment } \\
6 \text { Remittances/Gifts/Donations } \\
\text { from family or friends } \\
7 \text { Government assistance } \\
8 \text { Assistance from religious or } \\
\text { private organization } \\
-98 \text { Not applicable/none }\end{array}$ & $\begin{array}{l}\text { In the past } 12 \text { I } \\
\text { the estimated } \\
\text { household rece } \\
\text { THIRD most im } \\
\text { income? }\end{array}$ & $\begin{array}{l}\text { ths, what was } \\
\text { me your } \\
\text { from the } \\
\text { ant source of }\end{array}$ \\
\hline & $I \ldots I$ & 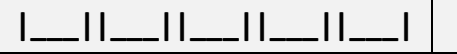 & \multicolumn{2}{|c|}{$I \ldots I \ldots I$} & \multicolumn{2}{|c|}{ 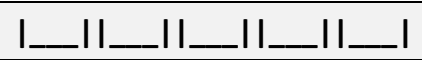 } & I_I_I I & \multicolumn{2}{|c|}{ 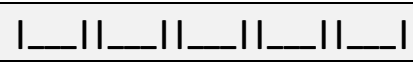 } \\
\hline D.9. & \multicolumn{2}{|c|}{$\begin{array}{l}\text { In the past } 12 \text { months, did you or a member of your } \\
\text { household provide any remittance or gift of cash to friends } \\
\text { or family member? }\end{array}$} & $\begin{array}{l}0 \text { No } \\
1 \text { Yes }\end{array}$ & I_I & D.10. & \multicolumn{2}{|c|}{$\begin{array}{l}\text { When you or a member of your household last provided } \\
\text { remittances or a gift in cash, how was the money sent } \\
\text { to the friend or family member? }\end{array}$} & $\begin{array}{l}\text { Remittance } \\
\text { Codes }\end{array}$ & 1 \\
\hline D.11. & \multicolumn{2}{|c|}{$\begin{array}{l}\text { In the past } 12 \text { months, have you or has a member of your } \\
\text { household requested loans from any sources? }\end{array}$} & $\begin{array}{l}0 \text { No } \\
1 \text { Yes }\end{array}$ & I_I & D.12. & \multicolumn{2}{|c|}{$\begin{array}{l}\text { From what sources have you or has a member of your } \\
\text { household requested loans? }\end{array}$} & $\begin{array}{l}\text { Loan } \\
\text { Codes }\end{array}$ & 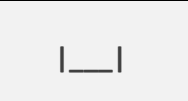 \\
\hline D.13. & \multicolumn{2}{|c|}{$\begin{array}{l}\text { In the past } 12 \text { months, have you or has a member of your } \\
\text { household received loans from this source (D.12)? }\end{array}$} & $\begin{array}{l}0 \text { No } \\
1 \text { Yes }\end{array}$ & I_I & D.14. & \multicolumn{2}{|c|}{$\begin{array}{l}\text { In the past } 12 \text { months, has anyone requested loans from } \\
\text { you? }\end{array}$} & $\begin{array}{l}0 \text { No } \\
1 \text { Yes }\end{array}$ & $\mathrm{I}$ \\
\hline D.15. & \multicolumn{2}{|c|}{$\begin{array}{l}\text { Who has requested loans from you or a member of your } \\
\text { household? }\end{array}$} & $\begin{array}{l}0 \text { No } \\
1 \text { Yes }\end{array}$ & I_I & D.16. & \multicolumn{2}{|c|}{$\begin{array}{l}\text { In the past } 12 \text { months, have you sent loans to this } \\
\text { person (D.15)? }\end{array}$} & $\begin{array}{l}\text { Borrower } \\
\text { Codes }\end{array}$ & I__ I \\
\hline D.17. & \multicolumn{2}{|c|}{$\begin{array}{l}\text { Does anyone in your household have a bank account with a } \\
\text { bank? }\end{array}$} & $\begin{array}{l}0 \text { No } \\
1 \text { Yes }\end{array}$ & $\mathrm{I}$ & D.18. & \multicolumn{2}{|c|}{$\begin{array}{l}\text { Who in your household has a bank account, either alone } \\
\text { or jointly? }\end{array}$} & $\begin{array}{l}\text { SELECT } \\
\text { MEMBERS }\end{array}$ & I_l;I_l \\
\hline
\end{tabular}


PROJECT SITE I___ I _

SECTION E. Emergency Preparedness

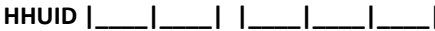

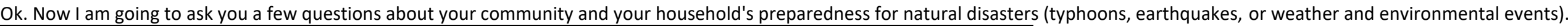

\begin{tabular}{|c|c|c|c|}
\hline E.1. & E.2. & E.3. & E.4. \\
\hline $\begin{array}{l}\text { How prepared do you feel your } \\
\text { community is if a natural } \\
\text { disaster were to hit your } \\
\text { barangay? } \\
1 \text { Very prepared } \\
2 \text { Prepared } \\
3 \text { Neither prepared nor } \\
\text { unprepared } \\
4 \text { Unprepared } \\
5 \text { Very unprepared }\end{array}$ & $\begin{array}{l}\text { If a typhoon were approaching this } \\
\text { region, how much advanced } \\
\text { warning do you expect you would } \\
\text { have? } \\
0 \text { None } \\
2 \text { Minutes } \\
3 \text { Hours } \\
4 \text { Days } \\
5 \text { Weeks } \\
6 \text { More than a month }\end{array}$ & $\begin{array}{l}\text { If evacuation were necessary, do } \\
\text { you think you would be able to } \\
\text { evacuate in time? } \\
\text { o No } \\
1 \text { Yes }\end{array}$ & $\begin{array}{l}\text { Has your household suffered } \\
\text { serious damage in the last year } \\
\text { from a typhoon? } \\
0 \text { No } \\
1 \text { Yes }\end{array}$ \\
\hline
\end{tabular}




\section{PROJECT SITE | \\ ADULT MODULE}

ENUMERATOR: ASK TO SPEAK WITH EACH OF THE ADULT MODULE RESPONDENTS IN PRIVATE.

\section{SECTION F: WELFARE}

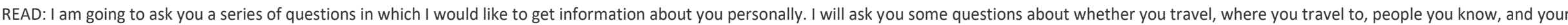
personal opinions.

\begin{tabular}{|c|c|c|c|c|}
\hline F.1. & F.2. & F.3. & F.4. & F.5. \\
\hline $\begin{array}{l}\text { All things considered, how } \\
\text { satisfied are you with your life } \\
\text { as a whole these days? } \\
\text { Using this card on which } 1 \\
\text { means you are "completely } \\
\text { dissatisfied" and } 10 \text { means you } \\
\text { are "completely satisfied" } \\
\text { where would you put your } \\
\text { satisfaction with your life as a } \\
\text { whole? }\end{array}$ & 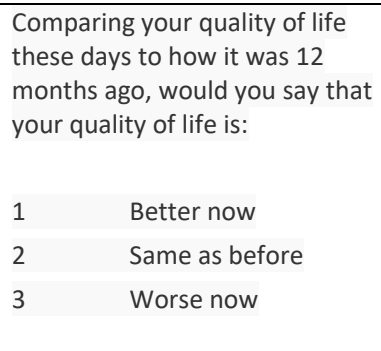 & 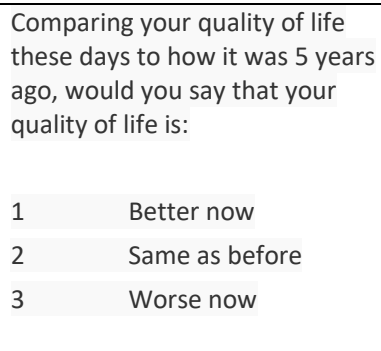 & $\begin{array}{l}\text { How satisfied are you with the } \\
\text { financial situation of your } \\
\text { household? } \\
\text { Using this card on which } 1 \text { means } \\
\text { you are "completely dissatisfied" } \\
\text { and } 10 \text { means you are "completely } \\
\text { satisfied" where would you put } \\
\text { your satisfaction with financial } \\
\text { situation? }\end{array}$ & $\begin{array}{l}\text { On a scale of } 1 \text { (very isolated) to } 5 \\
\text { (in very close contact), how } \\
\text { connected to you feel to your } \\
\text { friends and family who live outside } \\
\text { of the barangay? }\end{array}$ \\
\hline$I_{\ldots}$ & $I_{\ldots}$ & $I_{\ldots}$ & $I$ & I_I \\
\hline
\end{tabular}




\begin{tabular}{|c|c|c|}
\hline & G.1. & G.2. \\
\hline & $\begin{array}{l}\text { In the past } 12 \text { months, how frequently } \\
\text { did you leave [location_name] to visit } \\
\text {...? } \\
1 \text { Daily } \\
2 \text { Weekly } \\
3 \text { Monthly } \\
4 \text { A few times a year } \\
5 \text { Rarely (once or less a year) } \\
6 \text { Never }\end{array}$ & $\begin{array}{l}\text { For what purpose do you visit...? } \\
1 \text { For work (permanent, } 3 \text { months or longer) } \\
2 \text { For work (temporary, less than } 3 \text { months) } \\
3 \text { For school } \\
4 \text { To socialize with friends, family, or others } \\
5 \text { To sell goods } \\
6 \text { To buy agricultural inputs } \\
7 \text { To shop for general household shopping } \\
8 \text { For a financial transaction (at the bank or to make/receive a payment) } \\
9 \text { For medical or health reasons } \\
\text { Other (Specify) }\end{array}$ \\
\hline (i) The neighboring barangay & $I_{-}$ & I_I \\
\hline (iii) Baler & $I_{\ldots} I$ & $I_{\ldots} I_{1}$ \\
\hline (iv) Manila (3 years) & $\mathrm{I}$ & $I \ldots$ \\
\hline $\begin{array}{l}\text { (v) Any other place? } \\
\text { Specify: } \\
3 \text { Another barangay in the sam } \\
\text { Municipality: } \\
4 \text { Elsewhere in the Philippines } \\
\text { Province: } \\
5 \text { Outside of the Philippines } \\
\text { Other (Specify) }\end{array}$ & $I \ldots$ & $I$ \\
\hline
\end{tabular}




\section{SECTION H: Knowledge assessment}

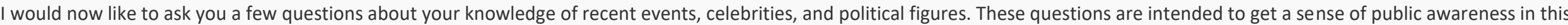
region of the Philippines. You will not be evaluated based on your answers. Please try to give me the most truthful answer about your own personal awareness.

\section{ENUMERATOR: DO NOT READ OPTIONS.}

\begin{tabular}{|c|c|c|c|c|}
\hline H.1. & H.2. & H.3. & H.4. & H.5. \\
\hline $\begin{array}{l}\text { Who is the President of the } \\
\text { Philippines? } \\
1 \text { Rodrigo Duterte } \\
2 \text { Benigno Aquino } \\
3 \text { Other } \\
-77 \text { Don't know/Uncertain }\end{array}$ & $\begin{array}{l}\text { What is the name of the Governor of } \\
\text { Aurora province? } \\
1 \text { Gerardo A. Noveras } \\
2 \text { Rommel Rico T. Angara } \\
3 \text { Other } \\
-77 \text { Don't know/Uncertain }\end{array}$ & $\begin{array}{l}\text { A national tax reform law was recently } \\
\text { put into implementation. What is the } \\
\text { name of the tax reform law? } \\
1 \text { TRAIN (Tax Reform for Acceleration } \\
\text { and Inclusion) } \\
2 \text { Tax Amnesty Act } \\
3 \text { Other } \\
-77 \text { Don't know/Uncertain }\end{array}$ & $\begin{array}{l}\text { The town of Dilasag, Aurora was placed } \\
\text { under a state of calamity in November } \\
\text { 2018. What was the name of the typhoon } \\
\text { that struck the town and surrounding } \\
\text { area? } \\
1 \text { Typhoon Rosita } \\
3 \text { Other } \\
-77 \text { Don't know/Uncertain }\end{array}$ & $\begin{array}{l}\text { A public health threat outbreak was } \\
\text { recently declared in Calabarzon Region as } \\
\text { well as other areas of the Philippines. } \\
\text { More than } 300 \text { people have died from this } \\
\text { outbreak. What infectious disease is the } \\
\text { reason for the outbreak? } \\
1 \text { Measles } \\
2 \text { Flu } \\
3 \text { Other } \\
-77 \text { Don't know/Uncertain }\end{array}$ \\
\hline$I_{1}$ & $I_{1}$ & $I_{1}$ & $I_{1}$ & $I_{\ldots}$ \\
\hline $\begin{array}{l}\text { Inflation is the change in prices for a } \\
\text { common basket of goods over a } \\
\text { period of time. Over the course of } \\
2018 \text {, was the official inflation rate } \\
\text { for the Philippines less than or } \\
\text { greater than } 5.0 \text { percent? } \\
1 \text { Greater than } 5 \text { percent } \\
2 \text { Less than } 5 \text { percent } \\
3 \text { Other } \\
-77 \text { Don't know/Uncertain }\end{array}$ & $\begin{array}{l}\text { Is the the minimum wage rate for Metro } \\
\text { Manila province greater than P600? } \\
\begin{array}{ll}1 & \text { Greater than } 600 \text { pesos } \\
2 & \text { Less than } 600 \text { pesos } \\
3 & \text { Other } \\
-77 & \text { Don't know/Uncertain }\end{array}\end{array}$ & $\begin{array}{l}\text { Is the minimum wage rate in } \\
\text { Aurora province greater than } \\
\text { P250? } \\
1 \text { Greater than } 250 \text { pesos } \\
2 \text { Less than } 250 \text { pesos } \\
3 \text { Other } \\
-77 \text { Don't know/Uncertain }\end{array}$ & $\begin{array}{l}\text { Who won in the Miss Universe } \\
\text { pageant in } 2018 \text { ? } \\
1 \text { Catriona Gray } \\
2 \text { Katarina Rodriguez } \\
3 \text { Other } \\
-77 \text { Don't know/Uncertain }\end{array}$ & $\begin{array}{l}\text { What is the name of the team that } \\
\text { won the 2017-18 Philippine Cup in } \\
\text { the Philippine Basketball } \\
\text { Association? } \\
1 \text { San Miguel Beermen } \\
2 \text { Magnolia Hotshots } \\
3 \text { Other } \\
-77 \text { Don't know/Uncertain }\end{array}$ \\
\hline
\end{tabular}

CCN Endline Survey - Page 14 of 28 - Version: 2019-05-07 


\section{SECTION I: Information sources}

\begin{tabular}{|c|c|c|}
\hline & \multicolumn{2}{|c|}{ I.1. } \\
\hline & \multicolumn{2}{|c|}{$\begin{array}{l}\text { People learn what is going on in the Philippines and the world from various } \\
\text { sources. For each of the following sources, please indicate whether you use it to } \\
\text { obtain information } \\
\text { (1) daily } \\
\text { (2) weekly } \\
\text { (3) monthly } \\
\text { (4) less than monthly } \\
\text { (5) never. }\end{array}$} \\
\hline (i) Daily newspaper or printed magazines & \multicolumn{2}{|c|}{$I_{\ldots} I$} \\
\hline (ii) TV news & \multicolumn{2}{|c|}{$I_{-} I$} \\
\hline (iii) Radio news & \multicolumn{2}{|c|}{1} \\
\hline (iv) Mobile phone & \multicolumn{2}{|c|}{$I_{-} I_{1}$} \\
\hline (v) Email & \multicolumn{2}{|c|}{1} \\
\hline (vi) Facebook, Twitter, or other social media & \multicolumn{2}{|c|}{$I_{\ldots}$} \\
\hline (vii) Talk with friends and colleagues & \multicolumn{2}{|c|}{$I_{\ldots} I$} \\
\hline I.2. Do you see yourself as part of your local community? & $I_{1}$ & \multirow{4}{*}{$\begin{array}{l}1 \text { Definitely } \\
2 \text { Perhaps } \\
3 \text { Neutral } \\
4 \text { Perhaps not } \\
5 \text { Definitely not } \\
-88 \text { Refused } \\
-77 \text { Don't Know/Uncertain }\end{array}$} \\
\hline 1.3. Do you feel isolated from the rest of your country? & $I_{-} I$ & \\
\hline $\begin{array}{l}\text { 1.4. Do you receive a fair price for the coconuts, fish, and } \\
\text { other products that you sell? }\end{array}$ & I_ I I & \\
\hline $\begin{array}{l}\text { I.5. In case of an emergency, do you feel you would be } \\
\text { able to communicate with family members outside of } \\
\text { this sitio? }\end{array}$ & $I_{-}$ & \\
\hline
\end{tabular}


PROJECT SITE I______ I

SECTION J: Household decision making

$$
\text { J.1. }
$$

In your household, who decides what to buy in the

market or what to cook for the family?

SELECT MULTIPLE

HH MEMBER IDS
J.2.

In your household, who decides when buying expensive things

for the household such as radio, TV, etc.?

SELECT MULTIPLE

HH MEMBER IDs
HHUID I______ I_________ I__

J.3.

In your household, who decides how to manage the household budget?

SELECT MULTIPLE

HH MEMBER IDs 


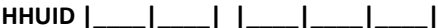

$$
\text { K.1. }
$$

\section{Which of the following activities does your household participate in?}

By participate, we mean runs a small, household enterprise or works for someone else.

1 Fishing, self-employed

2 Fishing for employer

3 Crop production (i.e. grows coconut, banana, pineapple, or other crop), self employed

4 Crop production (i.e. grows coconut, banana, pineapple, or other crop) for employer

5 Crop processing (i.e. grows coconut, banana, pineapple, or other crop), self employed

6 Crop processing (i.e. grows coconut, banana, pineapple, or other crop) for employer

7 None of the above

SELECT ALL THAT APPLY

\begin{tabular}{|c|c|c|c|}
\hline K.2. & K.3. & K.4. & K.5. \\
\hline $\begin{array}{l}\text { What are the fish species that are } \\
\text { most commonly caught by your } \\
\text { household? } \\
\text { See fish codes. }\end{array}$ & $\begin{array}{l}\text { Of the fish species } \\
\text { you mentioned } \\
\text { which is most } \\
\text { important for your } \\
\text { household's income? }\end{array}$ & $\begin{array}{l}\text { If you had gone to Baler this } \\
\text { morning to sell [main fish], } \\
\text { what price do you think you } \\
\text { would have received for that } \\
\text { fish per kilogram? } \\
\text { PESOS/kg }\end{array}$ & $\begin{array}{l}\text { If you had gone to Dingalan } \\
\text { this morning to sell [main } \\
\text { fish], what price do you } \\
\text { think you would have } \\
\text { received for that fish per } \\
\text { kilogram? } \\
\text { PESOS/kg }\end{array}$ \\
\hline I__l;I_lil_lil__lil__ & 1 & I_I_I_I_I_I & I_I_I_I_I_I \\
\hline К.6. & К.7. & K.8. & K.9. \\
\hline $\begin{array}{l}\text { What are primary crops that your } \\
\text { household produces? } \\
\text { See crop codes } \\
\text { SELECT UP TO THREE. }\end{array}$ & $\begin{array}{l}\text { Of the crops you } \\
\text { mentioned which is } \\
\text { most important for } \\
\text { your household's } \\
\text { income? }\end{array}$ & $\begin{array}{l}\text { If you had gone to Baler this } \\
\text { morning to sell your [main } \\
\text { crop], what price do you } \\
\text { think you would have } \\
\text { received per kilogram? } \\
\text { PESOS/kg }\end{array}$ & $\begin{array}{l}\text { If you had gone to Dingalan } \\
\text { this morning to sell [main } \\
\text { crop], what price do you } \\
\text { think you would have } \\
\text { received per kilogram? } \\
\text { PESOS/kg }\end{array}$ \\
\hline I__lil__lil__ & $\mathrm{I}$ & I_I_ا_I_ا_I_I_ا_I & 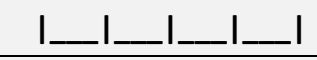 \\
\hline
\end{tabular}

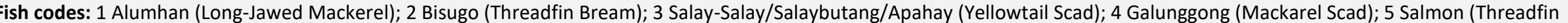

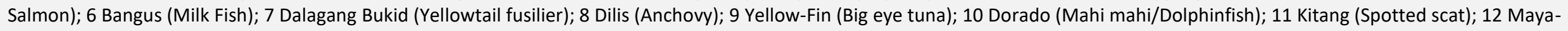

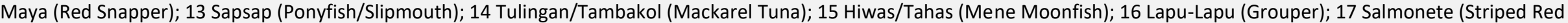
Mullet); 18 Tilapia; 19 Tawilis; 20 Crabs; 21 Shrimp; 22 Lobster; 23 Mussels; 24 Other Shellfish Other (Specify)

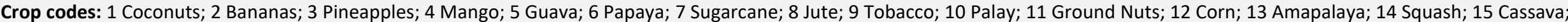
16 Sweet Potato; 17 Ginger; 18 Gabi/Taro; 19 Thatch; 20 Bamboo; 21 Flowers; 22 String Beans; Other (Specify) 


\begin{tabular}{|c|c|c|c|c|}
\hline K.10. & K.11. & K.12. & K.13. & K.14. \\
\hline 1 Yes & $\begin{array}{r}\text { SELECT MULTIPLE } \\
\text { HH MEMBER IDS }\end{array}$ & $\begin{array}{l}1 \text { No input or input in } \\
\text { few decisions } \\
2 \text { Input into some } \\
\text { decisions } \\
3 \text { Input into most or all } \\
\text { decisions }\end{array}$ & $\begin{array}{l}1 \text { Not at all } \\
2 \text { Small extent } \\
3 \text { Medium extent } \\
4 \text { To a large extent }\end{array}$ & $\begin{array}{l}1 \text { No input or input in } \\
\text { few decisions } \\
2 \text { Input into some } \\
\text { decisions } \\
3 \text { Input into most or all } \\
\text { decisions } \\
4 \text { No income made } \\
\text { from this activity }\end{array}$ \\
\hline
\end{tabular}

\begin{tabular}{|c|c|c|c|c|c|c|c|c|}
\hline & K.15. & K.16. & K.17. & K.18. & K.19. & K.20. & K.21. & K.22. \\
\hline$\sum_{\substack{\frac{1}{2} \\
\frac{1}{2}}}^{\sum_{L}}$ & $\begin{array}{l}\text { Have you or has } \\
\text { someone in } \\
\text { your household } \\
\text { sold [fishname] } \\
\text { in the past } 12 \\
\text { months? } \\
0 \text { No } \\
1 \text { Yes }\end{array}$ & $\begin{array}{l}\text { Which household members } \\
\text { conducted the sale of } \\
\text { [fishname]? } \\
\text { SELECT MULTIPLE HH } \\
\text { MEMBER IDs }\end{array}$ & $\begin{array}{l}\text { What was the date when } \\
\text { you last sold [fishname]? } \\
\text { Date }\end{array}$ & $\begin{array}{l}\text { On that date that you } \\
\text { last sold [fishname], } \\
\text { how much did you } \\
\text { sell in kilograms? } \\
\text { Record kilograms. }\end{array}$ & $\begin{array}{l}\text { Where did you last } \\
\text { sell [fishname]? } \\
1 \text { In the same } \\
\text { barangay } \\
2 \text { Dingalan } \\
3 \text { Baler } \\
\text { Other (specify) }\end{array}$ & $\begin{array}{l}\text { Did you know the price } \\
\text { for selling [fishname] } \\
\text { at the market before } \\
\text { you sold it there? } \\
0 \text { No } \\
1 \text { Yes }\end{array}$ & $\begin{array}{l}\text { What was the price } \\
\text { per kilogram that you } \\
\text { received when you } \\
\text { last sold the } \\
\text { [fishname]? } \\
\text { PESOS/kg }\end{array}$ & $\begin{array}{l}\text { Do you feel that you } \\
\text { receive a fair price for } \\
\text { the [fishname]? }\end{array}$ \\
\hline 01 & $\mathrm{I}$ & 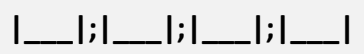 & 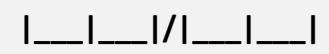 & I_I_I_I & I_I_I_I_I & 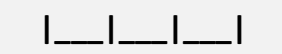 & I_I_I_I & $I \ldots I \_I \ldots I$ \\
\hline
\end{tabular}




\begin{tabular}{|c|c|c|c|c|}
\hline K.23. & К.24. & К.25. & К.26. & K.27. \\
\hline $\begin{array}{l}\text { Did you yourself participate in } \\
\text { farming in the past } 12 \text { months? } \\
0 \text { No } \\
1 \text { Yes }\end{array}$ & $\begin{array}{l}\text { When decisions are made regarding } \\
\text { farming, who is it that normally makes } \\
\text { the decision? } \\
\text { SELECT MULTIPLE } \\
\text { HH MEMBER IDs }\end{array}$ & $\begin{array}{l}\text { How much input did you have in } \\
\text { making decisions about farming? } \\
1 \text { No input or input in few decisions } \\
2 \text { Input into some decisions } \\
3 \text { Input into most or all decisions }\end{array}$ & $\begin{array}{l}\text { To what extent do you feel you can make } \\
\text { decisions regarding farming if you wanted } \\
\text { to? } \\
1 \text { Not at all } \\
2 \text { Small extent } \\
3 \text { Medium extent } \\
4 \text { To a large extent }\end{array}$ & $\begin{array}{l}\text { How much input did you have in decisions on the } \\
\text { use of income generated from farming? } \\
1 \text { No input or input in few decisions } \\
2 \text { Input into some decisions } \\
3 \text { Input into most or all decisions } \\
4 \text { No income made from this activity }\end{array}$ \\
\hline$I_{-} I_{1}$ & 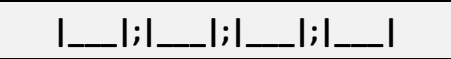 & $I \ldots$ & 1 & 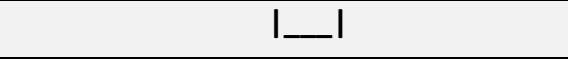 \\
\hline
\end{tabular}

\begin{tabular}{|c|c|c|c|c|c|c|c|c|}
\hline & K.28. & K.29. & K.30. & K.31. & K.32. & K.33. & K.34. & K.35. \\
\hline 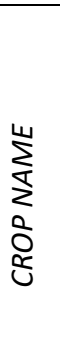 & $\begin{array}{l}\text { Have you or has } \\
\text { someone in } \\
\text { your household } \\
\text { sold [cropname] } \\
\text { in the past } 12 \\
\text { months? } \\
0 \text { No } \\
1 \text { Yes }\end{array}$ & $\begin{array}{l}\text { Which household members } \\
\text { conducted the sale of } \\
\text { [cropname]? } \\
\text { SELECT MULTIPLE HH } \\
\text { MEMBER IDs }\end{array}$ & $\begin{array}{l}\text { What was the date when } \\
\text { you last sold [cropname]? } \\
\text { Date }\end{array}$ & $\begin{array}{l}\text { On that date that you } \\
\text { last sold [cropname], } \\
\text { how much did you } \\
\text { sell in kilograms? }\end{array}$ & $\begin{array}{l}\text { Where did you last } \\
\text { sell [cropname]? } \\
1 \text { In the same } \\
\text { barangay } \\
2 \text { Dingalan } \\
3 \text { Baler } \\
\text { Other (specify) }\end{array}$ & $\begin{array}{l}\text { Did you know the price } \\
\text { for selling [cropname] } \\
\text { at the market before } \\
\text { you sold it there? } \\
0 \text { No } \\
1 \text { Yes }\end{array}$ & $\begin{array}{l}\text { What was the price } \\
\text { per kilogram that you } \\
\text { received when you } \\
\text { last sold the } \\
\text { [cropname]? } \\
\text { PESOS/kg }\end{array}$ & $\begin{array}{l}\text { Do you feel that you } \\
\text { receive a fair price for } \\
\text { the [cropname]? }\end{array}$ \\
\hline 01 & $I_{-} \mathrm{I}$ & 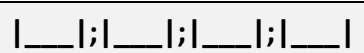 & $I_{\text {I }} I_{1} \mid / I_{-} I_{-}$ & I__I_I_I_I & I_I_I_I_I & I_I_I_I_I & I_I_I_I_I_I & I_I_I_I_I \\
\hline
\end{tabular}




\section{SECTION L: Social Networks}

Think for a moment about all of the people you know currently living WITHIN your barangay, [barangay_name]

L.1. How many different people, within the barangay, do you speak to on a regular basis?

These should be people that you know personally, not just acquaintances with whom you have occasional interactions.

Think for a moment about all of the people you know currently living outside of your barangay, [barangay_name].

L.2. How many different people, outside the barangay, do you speak to or see at least once a year?

These should be people that you know personally, not just acquaintances with whom you have occasional interactions.

\section{BARANGAY CONTACTS}

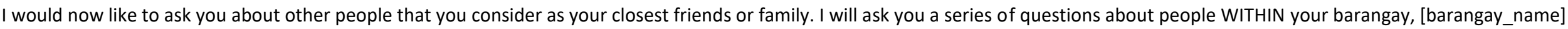

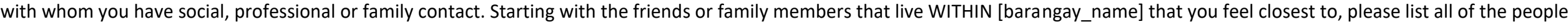

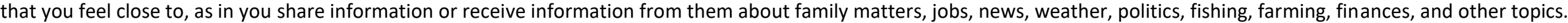
Excluding the people that you told me about within your household, what is the name of your \#1 closest friend or family member WITHIN [barangay_name]?

\begin{tabular}{|c|c|c|c|c|c|c|c|c|c|}
\hline & L.3. & L.4. & L.5. & L.6. & L.7. & L.8. & L.9. & L.10. & L.11. \\
\hline \multirow[b]{2}{*}{ 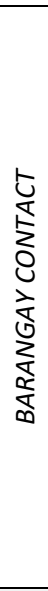 } & \multirow{2}{*}{$\begin{array}{l}\text { Nickname } \\
\text { If no nickname, re- } \\
\text { enter first name. }\end{array}$} & \multirow[t]{2}{*}{ First Name } & \multirow{2}{*}{$\begin{array}{l}\text { Last Name } \\
\text { ENTER -77 IF THEY } \\
\text { DON'T KNOW. }\end{array}$} & \multirow{2}{*}{$\begin{array}{l}\text { Is [bgy_nickname] } \\
\text { female or male? } \\
1 \text { Male } \\
2 \text { Female }\end{array}$} & \multirow{2}{*}{$\begin{array}{l}\text { What is [bgy_nickname]'s } \\
\text { age? } \\
1 \text { Under } 15 \text { years old } \\
215-30 \\
331-45 \\
445-65 \\
5 \text { Over } 65 \text { years old } \\
-88 \text { Refused } \\
-77 \text { Don't know }\end{array}$} & \multicolumn{3}{|c|}{ Where does [bgy_nickname] usually live? } & \multirow[b]{2}{*}{$\begin{array}{l}\text { What is [bgy_nickname]'s } \\
\text { relationship to you? } \\
1 \text { Unrelated, friend } \\
2 \text { Unrelated, work colleague } \\
3 \text { Unrelated, other } \\
4 \text { Wife or husband } \\
5 \text { Son or daughter } \\
6 \text { Son-/daughter-in-law } \\
7 \text { Grandchild } \\
8 \text { Father or mother } \\
9 \text { Grandfather or grandmother } \\
10 \text { Nephew or Niece } \\
11 \text { Aunt or Uncle } \\
12 \text { Brother or sister } \\
13 \text { Brother-/sister-in-law } \\
14 \text { Other relative } \\
\text { Other (Specify) }\end{array}$} \\
\hline & & & & & & Municipality & Barangay & Sitio/Purok & \\
\hline 01 & & & & $I_{-}$ & $I$ & & & & I_I_I_I \\
\hline 02 & & & & $\mathrm{I}$ & $\mathrm{I}$ & & & & I_I_I_I \\
\hline 03 & & & & $\mathrm{I}$ & $\mathrm{I}$ & & & & I_I_I_I \\
\hline 04 & & & & $I$ & $I$ & & & & I_I_I_I_L_ \\
\hline 05 & & & & $\mathrm{I}$ & $I \ldots I$ & & & & I_I_I_I \\
\hline
\end{tabular}

CCN Endline Survey - Page 20 of 28 - Version: 2019-05-07 


\begin{tabular}{|c|c|c|c|c|c|c|c|}
\hline & L.12. & L.13. & L.14. & L.15. & L.16. & L.17. & L.18. \\
\hline 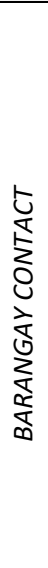 & $\begin{array}{l}\text { In the past } 12 \\
\text { months, how } \\
\text { often have you } \\
\text { communicated } \\
\text { with } \\
\text { [bgy_nickname] } \\
\text { in person? } \\
1 \text { Daily } \\
2 \text { Weekly } \\
3 \text { Monthly } \\
4 \text { Less than } \\
\text { once a month } \\
5 \text { Never }\end{array}$ & $\begin{array}{l}\text { In the past } 12 \\
\text { months, how } \\
\text { often have you } \\
\text { communicated } \\
\text { with } \\
\text { [bgy_nickname] } \\
\text { by phone? } \\
1 \text { Daily } \\
2 \text { Weekly } \\
3 \text { Monthly } \\
4 \text { Less than } \\
\text { once a month } \\
5 \text { Never }\end{array}$ & $\begin{array}{l}\text { In the past } 12 \text { months, how } \\
\text { often have you } \\
\text { communicated with } \\
\text { [bgy_nickname] by social } \\
\text { media (Facebook)? } \\
1 \text { Daily } \\
2 \text { Weekly } \\
3 \text { Monthly } \\
4 \text { Less than once a } \\
\text { month } \\
5 \text { Never }\end{array}$ & $\begin{array}{l}\text { In the past } 12 \text { months have } \\
\text { you RECEIVED } \\
\text { REMITTANCES or money } \\
\text { from [bgy_nickname]? } \\
\text { Remittances or money that does } \\
\text { not need to be paid back. } \\
0 \text { No } \\
1 \text { Yes }\end{array}$ & $\begin{array}{l}\text { In the past } 12 \text { months, how } \\
\text { much money have you } \\
\text { received in remittances from } \\
\text { [bgy_nickname]? } \\
\text { PESOS }\end{array}$ & $\begin{array}{l}\text { In the past } 12 \text { months have } \\
\text { you SENT REMITTANCES or } \\
\text { money to[bgy_nickname]? } \\
\text { Remittances or money that does } \\
\text { not need to be paid back. } \\
0 \text { No } \\
1 \text { Yes }\end{array}$ & $\begin{array}{l}\text { In the past } 12 \text { months, how } \\
\text { much money have you sent } \\
\text { in remittances to } \\
\text { [bgy_nickname]? } \\
\text { PESOS }\end{array}$ \\
\hline 01 & $I_{-} I$ & $I_{-} I$ & 1 & $\mathrm{I}$ & 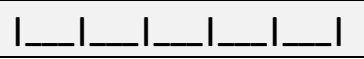 & $I_{-} I$ & 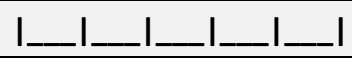 \\
\hline 02 & $I_{-} I$ & $I_{-} I$ & $\mathrm{I}$ & 1 & 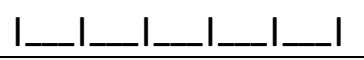 & $I_{-}$ & 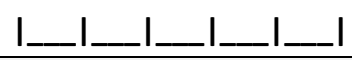 \\
\hline 03 & $I_{-}$ & $I_{-} I$ & $I_{-} I$ & $I_{-} I$ & 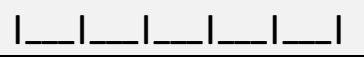 & $I_{-} I$ & 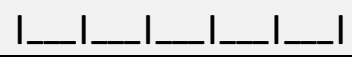 \\
\hline 04 & $I_{-}$ & $I_{-}$ & $I_{-}$ & $I_{-}$ & 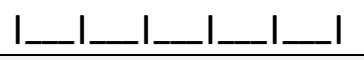 & $I_{-}$ & 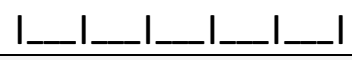 \\
\hline 05 & $I_{\ldots}$ & I__ I & $I_{\ldots} I$ & I__ I & 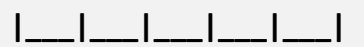 & I__ I & I_I_I_I_I_I_I_I_I I I \\
\hline
\end{tabular}




\begin{tabular}{|c|c|c|c|c|}
\hline & L.19. & L.20. & L.21. & L.22. \\
\hline 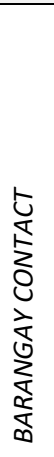 & $\begin{array}{l}\text { In the past } 12 \\
\text { months have } \\
\text { you received a } \\
\text { loan, either in } \\
\text { cash or in kind, } \\
\text { from } \\
\text { [bgy_nickname]? } \\
0 \text { No } \\
1 \text { Yes }\end{array}$ & $\begin{array}{l}\text { In the past } 12 \text { months, how } \\
\text { much money have you } \\
\text { received in loans from } \\
\text { [bgy_nickname]? } \\
\text { PESOS }\end{array}$ & $\begin{array}{l}\text { In the past } 12 \\
\text { months have you } \\
\text { provided a loan, } \\
\text { either in cash or in } \\
\text { kind, to } \\
\text { [bgy_nickname]? } \\
0 \text { No } \\
1 \text { Yes }\end{array}$ & $\begin{array}{l}\text { In the past } 12 \text { months, how } \\
\text { much money have you sent } \\
\text { in loans to [bgy_nickname]? } \\
\text { PESOS }\end{array}$ \\
\hline 01 & I__ I & 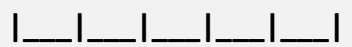 & 1 & I_I_I_I_I_I_I_ا_I \\
\hline 02 & I_I & 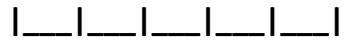 & $\mathrm{I}$ & 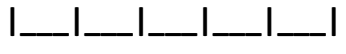 \\
\hline 03 & 1 & 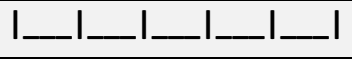 & $I$ & I_I_I_I_I_I_I_L_ \\
\hline 04 & 1 & 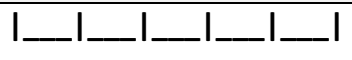 & 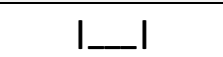 & 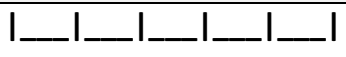 \\
\hline 05 & 1 & 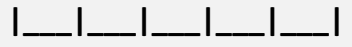 & 1 & 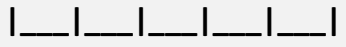 \\
\hline
\end{tabular}


PROJECT SITE I___ I__ I

HHUID I 1

\section{NON-BARANGAY CONTACTS}

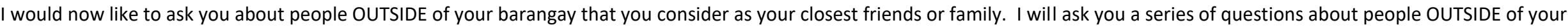

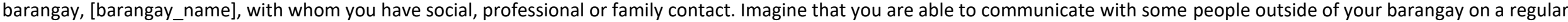

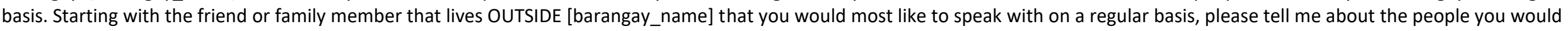
like to communicate with on a regular basis.

What is the name of your \#1 closest friend or family member OUTSIDE [barangay_name]?

\begin{tabular}{|c|c|c|c|c|c|c|c|c|c|c|}
\hline & L.23. & L.24. & L.25. & L.26. & L.27. & L.28. & L.29. & L.30. & L.31. & L.32. \\
\hline \multirow[b]{2}{*}{ 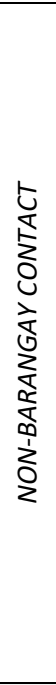 } & \multirow[t]{2}{*}{$\begin{array}{l}\text { Nickname } \\
\text { If no nickname, } \\
\text { re-enter first } \\
\text { name. }\end{array}$} & \multirow[t]{2}{*}{ First Name } & \multirow[t]{2}{*}{$\begin{array}{l}\text { Last Name } \\
\text { ENTER -77IF } \\
\text { THEY DON'T } \\
\text { KNOW. }\end{array}$} & \multirow[t]{2}{*}{$\begin{array}{l}\text { Is } \\
\text { [nonbgy_nickname] } \\
\text { female or male? } \\
1 \text { Male } \\
2 \text { Female }\end{array}$} & \multirow{2}{*}{$\begin{array}{l}\text { What is } \\
\text { [nonbgy_nickname]'s } \\
\text { age? } \\
1 \text { Under } 15 \text { years old } \\
215-30 \\
331-45 \\
445-65 \\
5 \text { Over } 65 \text { years old } \\
-88 \text { Refused } \\
-77 \text { Don't know }\end{array}$} & $\begin{array}{l}\text { Has } \\
\text { [nonbgy_nickname] } \\
\text { lived in this } \\
\text { barangay, } \\
\text { [barangay_name] } \\
\text { in the past three } \\
\text { years? }\end{array}$ & \multicolumn{3}{|c|}{ Where does [nonbgy_nickname] currently live? } & \multirow{2}{*}{$\begin{array}{l}\text { What is } \\
\text { [nonbgy_nickname]'s } \\
\text { relationship to you? } \\
1 \text { Unrelated, friend } \\
2 \text { Unrelated, work } \\
\text { colleague } \\
3 \text { Unrelated, other } \\
4 \text { Wife or husband } \\
5 \text { Son or daughter } \\
6 \text { Son-/daughter-in-law } \\
7 \text { Grandchild } \\
8 \text { Father or mother } \\
9 \text { Grandfather or } \\
\text { grandmother } \\
10 \text { Nephew or Niece } \\
11 \text { Aunt or Uncle } \\
12 \text { Brother or sister } \\
13 \text { Brother-/sister-in-lan } \\
14 \text { Other relative } \\
\text { Other (Specify) }\end{array}$} \\
\hline & & & & & & & Municipality & Barangay & Sitio/Purok & \\
\hline 02 & & & & $I_{-} I$ & $I_{1}$ & & & & & I_I_I_ \\
\hline 03 & & & & $I_{1} I$ & $I_{-} I_{1}$ & & & & & I_I_I_I_L_ \\
\hline 04 & & & & 1 & $\mathrm{I}$ & & & & & I_I_I_I_I \\
\hline 05 & & & & $I_{\ldots} I_{1}$ & $I_{\ldots} I_{1}$ & & & & & I_I_I_I \\
\hline
\end{tabular}




\begin{tabular}{|c|c|c|c|c|c|}
\hline & L.33. & L.34. & L.35. & L.36. & L.37. \\
\hline 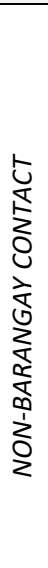 & $\begin{array}{l}\text { In the past } 12 \\
\text { months, how often } \\
\text { have you } \\
\text { communicated with } \\
\text { [nonbgy_nickname] } \\
\text { in person? } \\
1 \text { Daily } \\
2 \text { Weekly } \\
3 \text { Monthly } \\
4 \text { Less than once } \\
\text { a month } \\
5 \text { Never }\end{array}$ & $\begin{array}{l}\text { In the past } 12 \\
\text { months, how often } \\
\text { have you } \\
\text { communicated } \\
\text { with } \\
\text { [nonbgy_nickname] } \\
\text { by phone? } \\
1 \text { Daily } \\
2 \text { Weekly } \\
3 \text { Monthly } \\
4 \text { Less than once a } \\
\text { month } \\
5 \text { Never }\end{array}$ & $\begin{array}{l}\text { Do you know } \\
\text { [nonbgy_nickname]'s } \\
\text { phone number? } \\
0 \text { No } \\
1 \text { Yes }\end{array}$ & $\begin{array}{l}\text { What is } \\
\text { [nonbgy_nickname]'s } \\
\text { phone number? }\end{array}$ & $\begin{array}{l}\text { In the past } 12 \\
\text { months, how often } \\
\text { have you } \\
\text { communicated with } \\
\text { [nonbgy_nickname] } \\
\text { by social media } \\
\text { (Facebook)? } \\
1 \text { Daily } \\
2 \text { Weekly } \\
3 \text { Monthly } \\
4 \text { Less than once } \\
\text { a month } \\
5 \text { Never }\end{array}$ \\
\hline 01 & I_I & 1 & 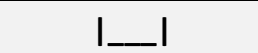 & & $I_{1}$ \\
\hline 02 & 1 & $I$ & 1 & & $I_{1}$ \\
\hline 03 & $I$ & I I & 1 & & $I_{\ldots}$ \\
\hline 04 & $I_{1}$ & $I$ & $I_{1}$ & & $I_{\ldots}$ \\
\hline 05 & I_I & $I$ & I_I & & I_I I \\
\hline
\end{tabular}




\begin{tabular}{|c|c|c|c|c|c|c|c|c|}
\hline & L.38. & L.39. & L.40. & L.41. & L.42. & L.43. & L.44. & L.45. \\
\hline 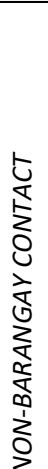 & $\begin{array}{l}\text { In the past } 12 \\
\text { months have you } \\
\text { RECEIVED } \\
\text { REMITTANCES or } \\
\text { money from } \\
\text { [nonbgy_nickname]? } \\
\text { Remittances or money } \\
\text { that does not need to } \\
\text { be paid back. } \\
0 \text { No } \\
1 \text { Yes }\end{array}$ & $\begin{array}{l}\text { In the past } 12 \text { months, } \\
\text { how much money have } \\
\text { you received in } \\
\text { remittances from } \\
\text { [nonbgy_nickname]? } \\
\text { PESOS }\end{array}$ & $\begin{array}{l}\text { In the past } 12 \text { months } \\
\text { have you SENT } \\
\text { REMITTANCES or } \\
\text { money } \\
\text { to[nonbgy_nickname]? } \\
\text { Remittances or money } \\
\text { that does not need to be } \\
\text { paid back. } \\
0 \text { No } \\
1 \text { Yes }\end{array}$ & $\begin{array}{l}\text { In the past } 12 \text { months, } \\
\text { how much money have } \\
\text { you sent in remittances } \\
\text { to [nonbgy_nickname]? } \\
\text { PESOS }\end{array}$ & $\begin{array}{l}\text { In the past } 12 \\
\text { months have you } \\
\text { received a loan, } \\
\text { either in cash or in } \\
\text { kind, from } \\
\text { [nonbgy_nickname]? } \\
0 \text { No } \\
1 \text { Yes }\end{array}$ & $\begin{array}{l}\text { In the past } 12 \text { months, how } \\
\text { much money have you } \\
\text { received in loans from } \\
\text { [nonbgy_nickname]? } \\
\text { PESOS }\end{array}$ & $\begin{array}{l}\text { In the past } 12 \\
\text { months have you } \\
\text { provided a loan, } \\
\text { either in cash or in } \\
\text { kind, to } \\
\text { [nonbgy_nickname]? } \\
0 \text { No } \\
1 \text { Yes }\end{array}$ & $\begin{array}{l}\text { In the past } 12 \text { months, how } \\
\text { much money have you } \\
\text { sent in loans to } \\
\text { [nonbgy_nickname]? } \\
\text { PESOS }\end{array}$ \\
\hline 02 & $\mathrm{I}$ & I_I_I_I_I_I_I_L & $\mathrm{I}$ & I_I_I_I_I_I_I_L & I_I & 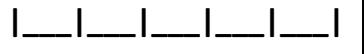 & I_I & I_I_I_I_I_I_I_L \\
\hline 03 & I_I & I_I_I_I_I_I_L & I_I & I_I_ا_I_I_I_I_ا_ & I_I & 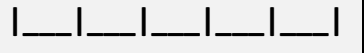 & I_I & I_I_I_I_I_I_I_L \\
\hline 04 & $I_{1}$ & 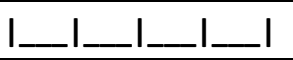 & 1 & 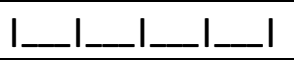 & $I_{1}$ & 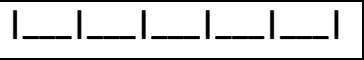 & $I_{\ldots} I$ & I____________ \\
\hline 05 & 1 & 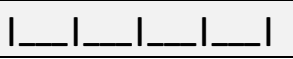 & 1 & 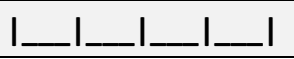 & 1 & 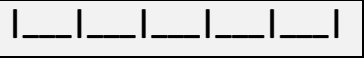 & $I_{\ldots} I$ & I__________ I I \\
\hline
\end{tabular}




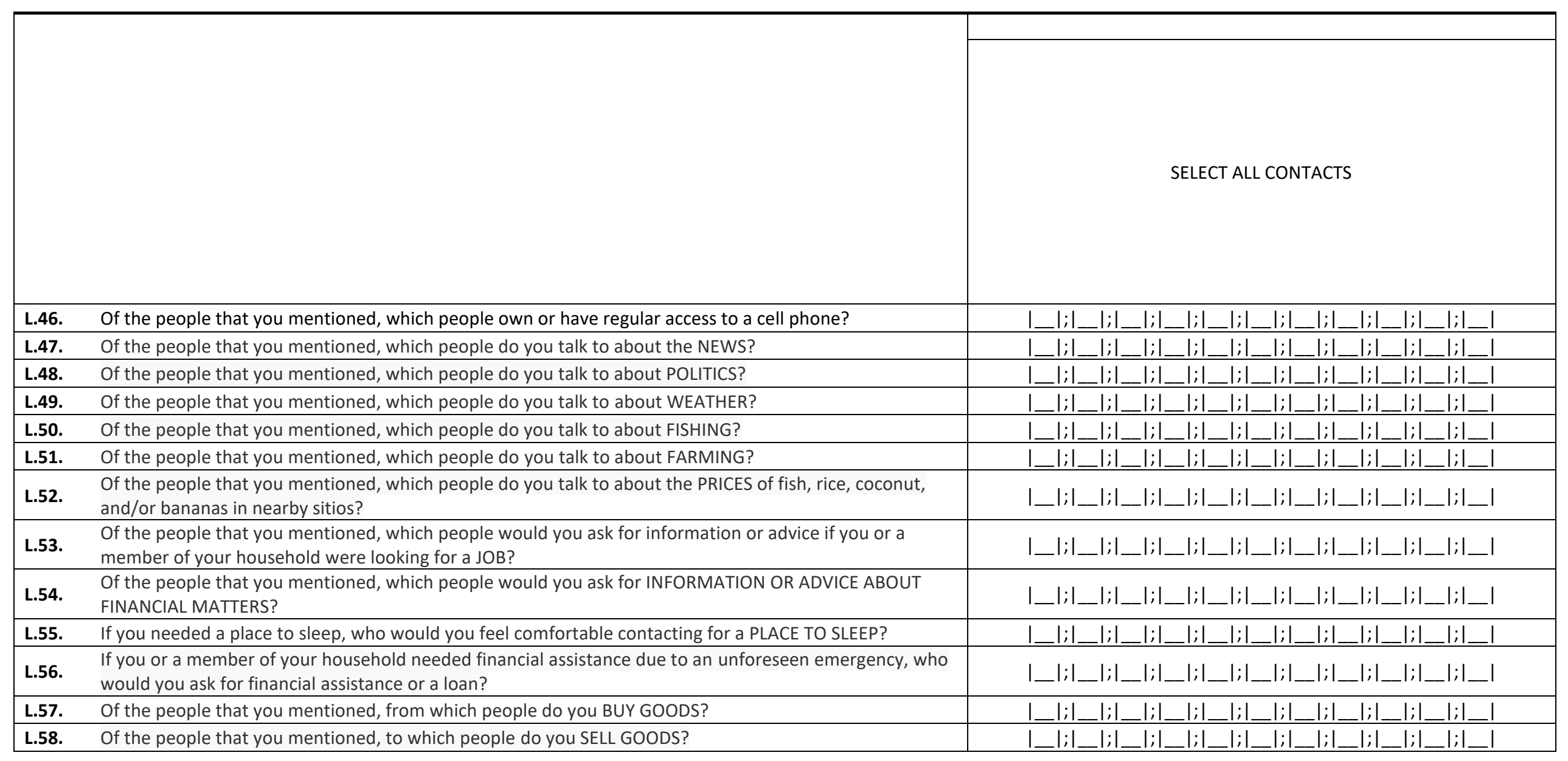


PROJECT SITE I___

HHUID I

SECTION M: Politics

Finally, I would like to ask you about your experience in recent political elections.

\begin{tabular}{|c|c|c|c|}
\hline M.1. & M.2. & M.3. & M.4. \\
\hline $\begin{array}{l}\text { In the last } 6 \\
\text { months, how } \\
\text { many times did } \\
\text { you talk to the } \\
\text { barangay } \\
\text { captain? } \\
1 \text { Often } \\
2 \text { Sometimes } \\
3 \text { Rarely } \\
4 \text { Never }\end{array}$ & $\begin{array}{l}\text { Did you vote in } \\
\text { the } 2019 \\
\text { election? } \\
0 \text { No } \\
1 \text { Yes }\end{array}$ & $\begin{array}{l}\text { Did someone offer } \\
\text { you money (or } \\
\text { something of value) } \\
\text { for your vote? } \\
\text { Ask about money or } \\
\text { something of value } \\
0 \text { No } \\
1 \text { Yes }\end{array}$ & $\begin{array}{l}\text { Which of these people } \\
\text { know how you voted? } \\
1 \text { Spouse } \\
2 \text { Friends } \\
3 \text { Barangay captain } \\
4 \text { Neighbors } \\
5 \text { Other family members } \\
0 \text { None of the above }\end{array}$ \\
\hline I_I & I__ I & I_I & I_I \\
\hline
\end{tabular}

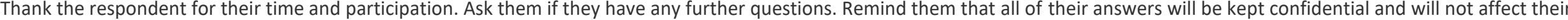
participation, either in the present or in the future, with any program or NGO. 
Y.4.

On a scale of 1 (poorest) to 10 (wealthiest), how wealthy do you think the respondent's household is in comparison with other households in

[barangay_name]?

1 Salvaged/makeshift materials, mixed but predominantly salvaged materials, light materials (cogon,

nipa, anahaw), or mixed but

predominantly light materials

2 Mixed but predominantly strong

materials

3 Strong materials (galvanized iron,

aluminum, tile, concrete, brick, stone,

wood, plywood, asbestos)

Other (Specify)

What is the primary material used for

the dwelling's roof?

1 Thatch/Grass

2 Palm leaf

3 Wood

4 Metal/Tin

5 Plastic

Other (Specify)
Y.3.

dwelling's floor?

1 Dirt/Mud

2 Tiles

3 Cement

4 Plastic

5 Wood

Other (Specify)

\begin{tabular}{|c|c|c|c|}
\hline I_I & I_I & $I \ldots I$ & I_I_I_I \\
\hline
\end{tabular}

Standing near the entrance to the respondent's dwelling, record the GPS coordinates. Wait until the accuracy is below $5 \mathrm{~m}$.

\begin{tabular}{|c|c|c|}
\hline Y.5. & Latitude & 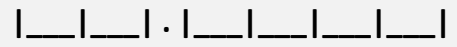 \\
\hline Y.6. & Longitude & I_I_I I_I_I_I_I_I \\
\hline Y.7. & Altitude & 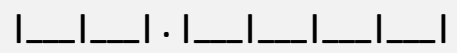 \\
\hline Y.8. & Accuracy & I_I_I_I_I \\
\hline
\end{tabular}

\section{END OF THE SURVEY}




\subsection{Endline Community Survey}




\section{INNOVATIONS FOR POVERTY ACTION}

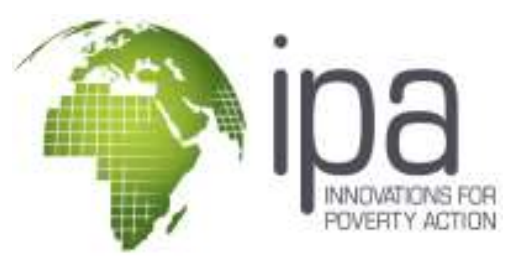

\section{CONNECTING ISOLATED COMMUNITIES 2019 - COMMUNITY SURVEY}

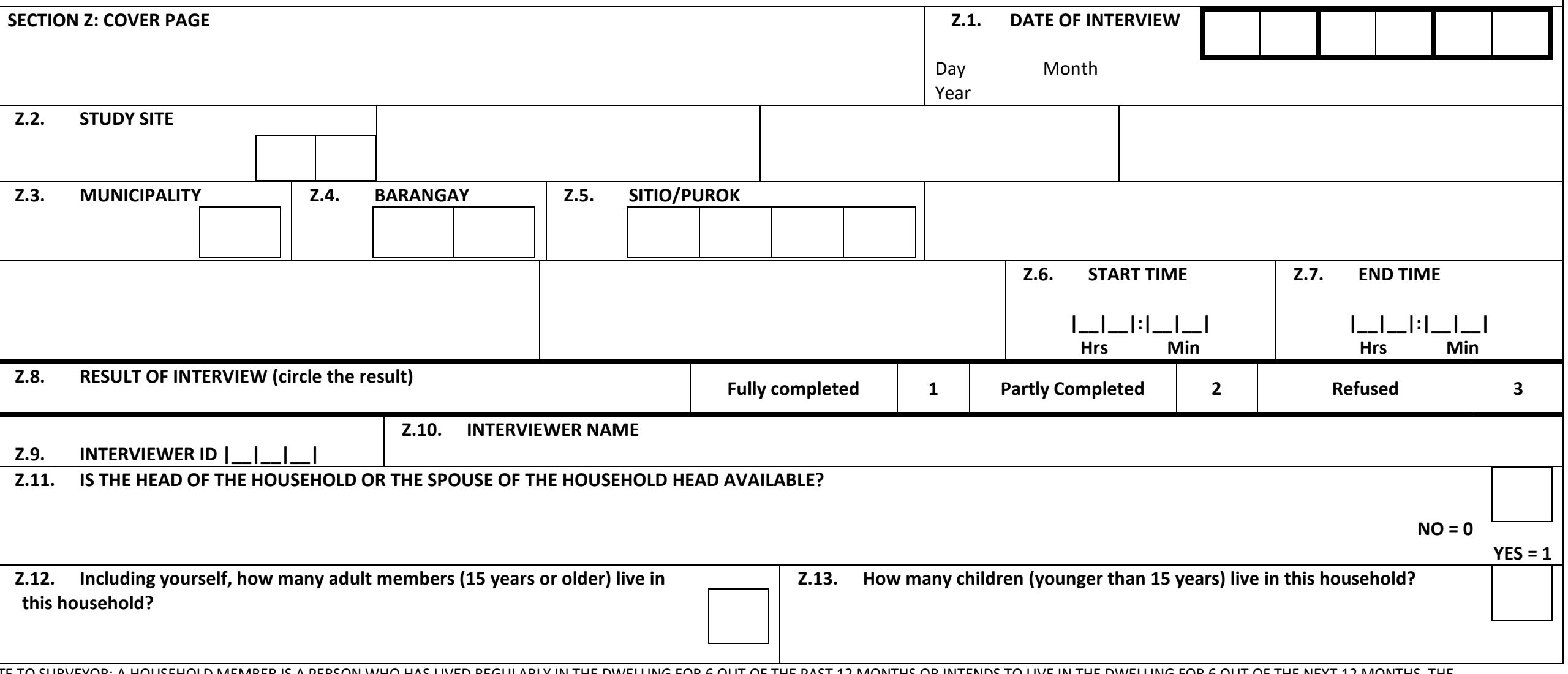

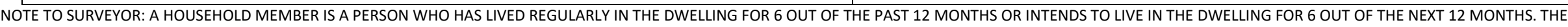
HOUSEHOLD HEAD IS THE INDIVIDUAL WITH PRIMARY RESPONSIBILITY FOR DECISIONS ABOUT HOUSEHOLD FINANCES. 
PROJECT SITE I______ I

SECTION A. COMMUNITY SURVEY PARTICIPANTS - DEMOGRAPHIC INFORMATION

HHUID I_____ I I_______ I I

ENUMERATOR: The following information must be obtained for every person participating in the community survey.

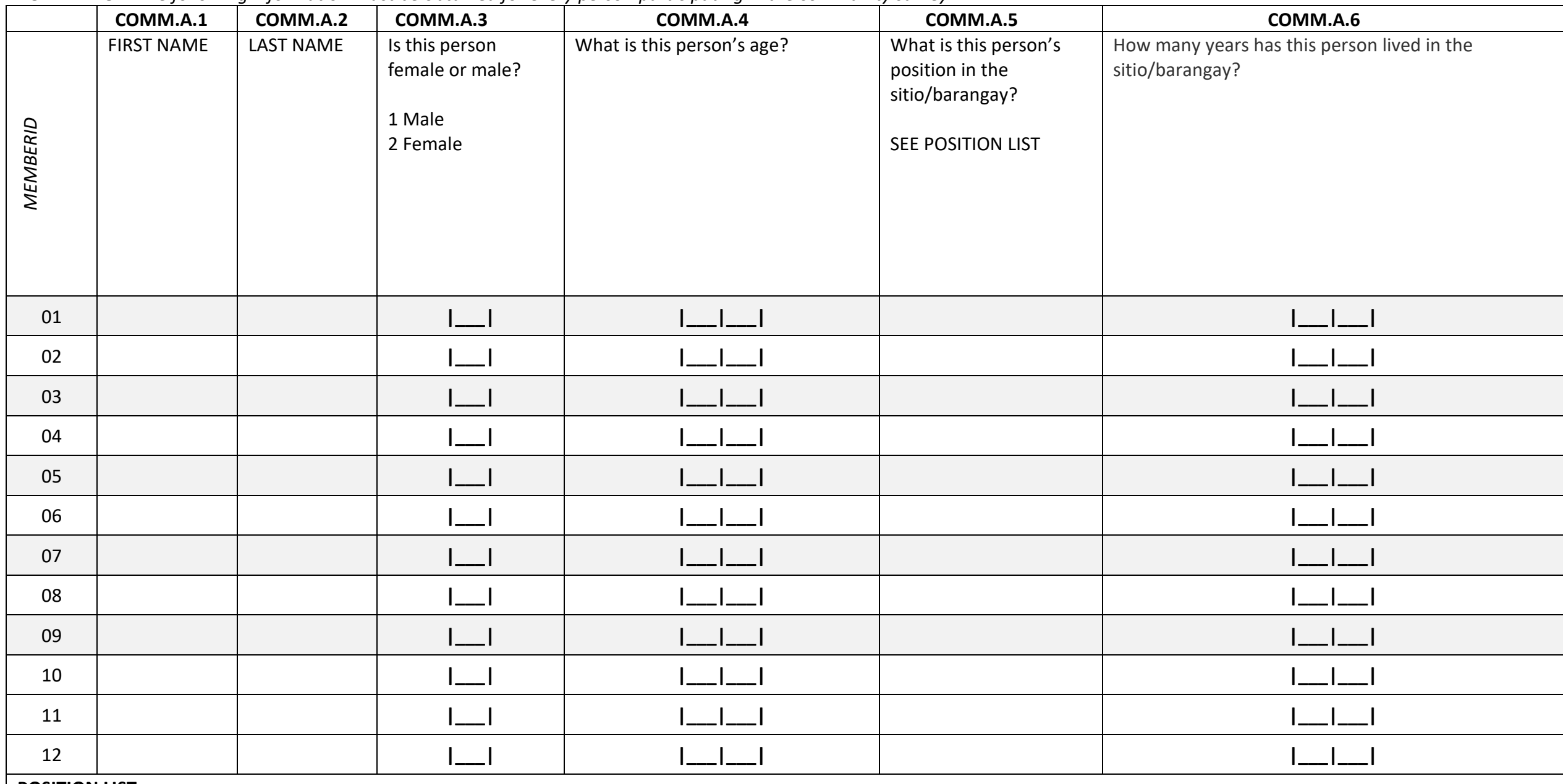

\section{POSITION LIST}

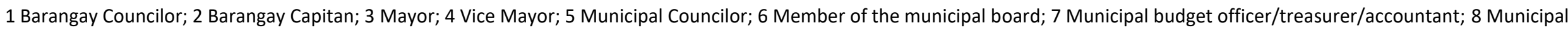

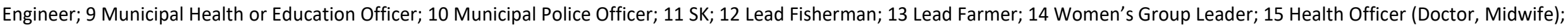
16 Teacher/Principal; 17 Disaster Risk Reduction or Management Officer; Other 


\section{SECTION B. General Information}

\begin{tabular}{|c|c|c|c|c|c|}
\hline COMM.B.1 & COMM.B.2 & COMM.B.3 & COMM.B.4 & COMM.B.5 & COMM.B.6 \\
\hline $\begin{array}{l}\text { How many churches } \\
\text { (congregations are there } \\
\text { in this sitio/barangay? }\end{array}$ & $\begin{array}{l}\text { Are there any protected } \\
\text { indigenous populations living } \\
\text { in this sitio/barangay? } \\
0 \text { No } \\
1 \text { Yes }\end{array}$ & $\begin{array}{l}\text { Is there a primary school in } \\
\text { this sitio/barangay? } \\
0 \text { No } \\
1 \text { Yes >> B. } 5\end{array}$ & $\begin{array}{l}\text { How much time would it take } \\
\text { for a typical person in this } \\
\text { community to get to the } \\
\text { nearest primary school } \\
\text { serving this sitio/barangay? } \\
\text { Minutes }\end{array}$ & $\begin{array}{l}\text { Is there a secondary school in } \\
\text { this sitio/barangay? } \\
0 \text { No } \\
1 \text { Yes >> B.7 }\end{array}$ & $\begin{array}{l}\text { How much time would it take } \\
\text { for a typical person in this } \\
\text { community to get to the } \\
\text { nearest secondary school } \\
\text { serving this sitio/barangay? } \\
\text { Minutes }\end{array}$ \\
\hline COMM.B.7 & COMM.B.8 & COMM.B.9 & COMM.B.10 & COMM.B.11 & COMM.B.12 \\
\hline $\begin{array}{l}\text { Is there a health clinic or } \\
\text { hospital this } \\
\text { sitio/barangay? } \\
0 \text { No } \\
1 \text { Yes >> B.9 }\end{array}$ & $\begin{array}{l}\text { How much time would it take } \\
\text { a typical person in this } \\
\text { community to get to the } \\
\text { nearest health clinic or } \\
\text { hospital serving this } \\
\text { sitio/barangay? } \\
\text { Minutes }\end{array}$ & $\begin{array}{l}\text { Over the past } 12 \text { months, } \\
\text { where there any disease } \\
\text { outbreaks within the } \\
\text { barangay? } \\
0 \text { No } \\
1 \text { Yes >> B.12 }\end{array}$ & $\begin{array}{l}\text { What were the outbreaks? } \\
1 \text { Dengue } \\
2 \text { Measles } \\
3 \text { Flu } \\
\text { Other }\end{array}$ & $\begin{array}{l}\text { During the past } 12 \text { months, in } \\
\text { which months was there a } \\
\text { disease outbreak that } \\
\text { affected this sitio/barangay? } \\
\text { SELECT ALL MONTHS THAT } \\
\text { APPLY }\end{array}$ & $\begin{array}{l}\text { Is there a commercial bank in } \\
\text { this sitio/barangay? } \\
0 \text { No } \\
1 \text { Yes >> B.14 }\end{array}$ \\
\hline$I_{-}$ & I_I_I_I_I_I & I_ I & I__lil_lil_ & $I_{\ldots}$ & $I_{-} I$ \\
\hline СОММ.B.13 & СомМ.B.14 & & & & \\
\hline $\begin{array}{l}\text { How much time would it } \\
\text { take a typical person in } \\
\text { this community to get to } \\
\text { the nearest commercial } \\
\text { bank serving this } \\
\text { sitio/barangay? } \\
\text { Minutes }\end{array}$ & $\begin{array}{l}\text { Which activities at the most } \\
\text { important sources of } \\
\text { employment for individuals } \\
\text { in this sitio/barangay? } \\
\text { SEE ACTIVITY LIST } \\
\text { Select all that apply. }\end{array}$ & & & & \\
\hline I_I_I_I_I_I & I_I & & & & \\
\hline
\end{tabular}

CCN Endline Community Survey - Page 3 of 9 - Version: 2019-05-31 


\section{SECTION C: Migration}

\begin{tabular}{|c|c|c|c|c|c|}
\hline COMM.C.1 & COMM.C.2 & COMM.C.3 & COMM.C.4 & COMM.C.5 & COMM.C.6 \\
\hline $\begin{array}{l}\text { In the last three years, } \\
\text { have there been more } \\
\text { people who moved into } \\
\text { this community or more } \\
\text { people who moved away? } \\
1 \text { More moved IN } \\
2 \text { More moved OUT } \\
3 \text { About the same of both } \\
4 \text { Neither arrivals nor } \\
\text { departures }\end{array}$ & $\begin{array}{l}\text { What are the primary ways } \\
\text { that people get to a from this } \\
\text { sitio/barangay? } \\
1 \text { Foot/Walking } \\
2 \text { Boat } \\
3 \text { Bicycle } \\
4 \text { Motorcycle } \\
5 \text { Car or truck } \\
6 \text { Bus }\end{array}$ & $\begin{array}{l}\text { How much time would it } \\
\text { take a typical person in this } \\
\text { sitio/barangay to get to } \\
\text { Baler? } \\
\text { Minutes }\end{array}$ & $\begin{array}{l}\text { How much would it cost a } \\
\text { typical person in this } \\
\text { sitio/barangay to travel to } \\
\text { Baler? } \\
\text { PESOS }\end{array}$ & $\begin{array}{l}\text { How much time would it take } \\
\text { a typical person in this } \\
\text { sitio/barangay to get to } \\
\text { Dingalan? } \\
\text { Minutes }\end{array}$ & $\begin{array}{l}\text { How much would it cost a } \\
\text { typical person in this } \\
\text { sitio/barangay to travel to } \\
\text { Dingalan? } \\
\text { PESOS }\end{array}$ \\
\hline$I_{\ldots} I$ & I_l;I_l;I_I & I_I_I_I_I I & 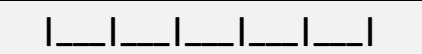 & I_I & I_I \\
\hline COMM.C.7 & COMM.C.8 & COMM.C.9 & COMM.C.10 & COMM.C.11 & COMM.C.12 \\
\hline $\begin{array}{l}\text { How much time would it } \\
\text { take a typical person in } \\
\text { this sitio/barangay to get } \\
\text { to Manila? } \\
\text { Minutes }\end{array}$ & $\begin{array}{l}\text { How much would it cost a } \\
\text { typical person in this } \\
\text { sitio/barangay to travel to } \\
\text { Manila? } \\
\text { PESOS }\end{array}$ & $\begin{array}{l}\text { During the past } 12 \text { months, } \\
\text { were there any months } \\
\text { when it was difficult to get } \\
\text { to a from this } \\
\text { sitio/barangay due to } \\
\text { typhoons, earthquakes, } \\
\text { flooding, or other reasons? }\end{array}$ & $\begin{array}{l}\text { Why was it difficult to travel } \\
\text { to and from this } \\
\text { sitio/barangay? } \\
1 \text { Typhoon } \\
2 \text { Flooding } \\
3 \text { Earthquake }\end{array}$ & $\begin{array}{l}\text { During the past } 12 \text { months, in } \\
\text { which months was it difficult } \\
\text { to get to and from this } \\
\text { sitio/barangay do to } \\
\text { typhoons, earthquakes, } \\
\text { flooding, or other reasons } \\
\text { Select all that apply. }\end{array}$ & $\begin{array}{l}\text { Do people in this } \\
\text { sitio/barangay leave } \\
\text { temporarily during certain } \\
\text { times of the year to look for } \\
\text { work elsewhere? } \\
0 \text { No >> C.17 } \\
1 \text { Yes }\end{array}$ \\
\hline 1 & $I_{-} I$ & $I_{-} I$ & I__l; & $I_{\ldots}$ & $I_{\ldots} I$ \\
\hline COMM.C.13 & COMM.C.14 & COMM.C.15 & COMM.C.16 & & \\
\hline $\begin{array}{l}\text { What percentage of } \\
\text { household in this } \\
\text { sitio/barangay have } \\
\text { members leaving } \\
\text { temporarily to look for } \\
\text { work elsewhere? }\end{array}$ & $\begin{array}{l}\text { Where do most of them go? } \\
1 \text { To the same sitio/barangay } \\
2 \text { To the neighboring } \\
\text { barangay } \\
3 \text { To Baler } \\
4 \text { To Dingalan } \\
5 \text { To Manila } \\
6 \text { Elsewhere in the } \\
\text { Philippines } \\
7 \text { Outside of the Philippines }\end{array}$ & $\begin{array}{l}\text { What type of work do they } \\
\text { look for? } \\
\text { SEE ACTIVITY LIST }\end{array}$ & $\begin{array}{l}\text { During the past } 12 \text { months, in } \\
\text { which months did they most } \\
\text { commonly leave this } \\
\text { sitio/barangay? } \\
\text { Select all that apply. }\end{array}$ & & \\
\hline
\end{tabular}

CCN Endline Community Survey - Page 4 of 9 - Version: 2019-05-31 


\section{COMM.C.17}

Do people come to this

sitio/barangay during

certain times of the year

to look for work?

O NO $>$ NEXT SECTION

1 Yes

\section{COMM.C.18}

Where do most of them

come from?

1 The same sitio/barangay

2 The neighboring barangay

3 Baler

4 Dingalan

5 Manila

6 Elsewhere in the

Philippines

7 Outside of the Philippines

\begin{tabular}{c|c} 
I__ & I_lil__il__
\end{tabular}

\section{COMM.C.19}

What type of work to they

look for?

SEE ACTIVITY LIST $\quad$ sitio/barangay?

Select all that apply.

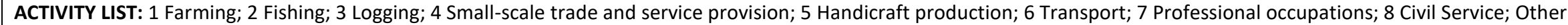


PROJECT SITE I___ I _ I I SECTION D: COMMUNICATIONS

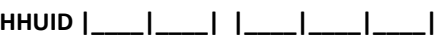

COMM.D.1

Is there a place in this

community where

person can pay to make a

telephone call - e.g., a

public telephone, a

telephone bureau, or a

telecenter offering

telephone services?

\section{COMM.D.2}

COMM.D.3

How much time would it take

for a typical person in this

sitio/barangay to get to the

nearest such place (e.g., a

Is there a place in this

community where a person

can pay to make a

telephone with a cell

COMM.D.6

public telephone, a

telephone bureau, or a

phone?

telecenter offering telephone

$0 \mathrm{No}$

services)?

1 Yes > D. 5

How much time would it take

for a typical person in this

sitio/barangay to get to the

sitio/barangay have

$\mathrm{CB}$ radio that can be used

nearest place to make a

to communicate with people

outside of the community?

Under what circumstances

can a person use the $C B$

radio?

telephone call with a cell

phone?

SELECT ALL THAT APPLY

1 To communicate during

weather emergencies

2 To get news updates

3 For government/official

communications

4 To get information about

fish prices

5 To get information about

agricultural prices

6 Personal communications

\begin{tabular}{|c|c|c|c|c|c|}
\hline$I_{-} I$ & 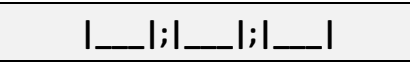 & I_I_I_I_I & 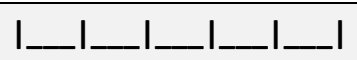 & I__ I & 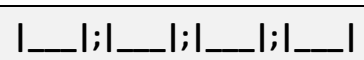 \\
\hline COMM.D.7 & COMM.D.8 & COMM.D.9 & COMM.D.10 & COMM.D.11 & COMM.D.12 \\
\hline $\begin{array}{l}\text { Do people need to pay to } \\
\text { use the CB radio? } \\
0 \text { No } \\
1 \text { Yes }\end{array}$ & $\begin{array}{l}\text { Does this sitio/barangay have } \\
\text { access to the internet? } \\
0 \text { No >> NEXT SECTION } \\
1 \text { Yes }\end{array}$ & $\begin{array}{l}\text { How do people access the } \\
\text { internet in this } \\
\text { sitio/barangay? } \\
1 \text { Wi-Fi signal } \\
2 \text { Landline/DSL } \\
3 \text { Globe connection } \\
4 \text { Smart connection } \\
5 \text { VBTS connection }\end{array}$ & & & \\
\hline$I_{-} I$ & $I_{-} I$ & $I_{-} I$ & I__l;I__lil__ & $I$ & $I_{-} I$ \\
\hline
\end{tabular}




\section{SECTION E: ECONOMIC ACTIVITIES}

\begin{tabular}{|c|c|c|c|c|c|c|}
\hline COMM.E.1 & COMM.E.2 & COMM.E.3 & COMM.E.4 & COMM.E.5 & COMM.E.6 & COMM.E.7 \\
\hline $\begin{array}{l}\text { Do any households } \\
\text { farm crops in this } \\
\text { sitio/barangay? } \\
0 \text { No »> } \\
1 \text { Yes }\end{array}$ & $\begin{array}{l}\text { What percentage of } \\
\text { households in this } \\
\text { sitio/barangay } \\
\text { participates in } \\
\text { farming? }\end{array}$ & $\begin{array}{l}\text { What are the main crops } \\
\text { grown in this } \\
\text { sitio/barangay? } \\
\text { SEE CROP CODES }\end{array}$ & $\begin{array}{l}\text { During the past } 12 \\
\text { months what were the } \\
\text { major planting months } \\
\text { for major crops in this } \\
\text { sitio/barangay? } \\
\text { SELECT ALL APPLICABLE } \\
\text { MONTHS }\end{array}$ & $\begin{array}{l}\text { During the past } 12 \\
\text { months what were the } \\
\text { major harvesting } \\
\text { months for major crops } \\
\text { in this sitio/barangay? } \\
\text { SELECT ALL APPLICABLE } \\
\text { MONTHS }\end{array}$ & $\begin{array}{l}\text { Where do people travel } \\
\text { to sell the crops that they } \\
\text { have harvested? } \\
1 \text { To the same } \\
\text { sitio/barangay } \\
2 \text { To the neighboring } \\
\text { barangay } \\
3 \text { To Baler } \\
4 \text { To Dingalan } \\
5 \text { To Manila } \\
6 \text { Elsewhere in the } \\
\text { Philippines } \\
7 \text { Outside of the } \\
\text { Philippines }\end{array}$ & $\begin{array}{l}\text { If there is more than one } \\
\text { market, how do you } \\
\text { think people decide } \\
\text { which market to go to } \\
\text { sell their crops? }\end{array}$ \\
\hline 1 & 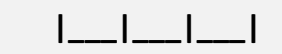 & 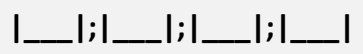 & I__lil_lil_lil_l & $I_{-} \mid$ & I__lil_lil_lil_l & \\
\hline
\end{tabular}

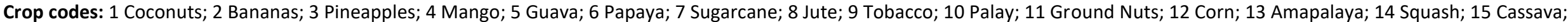
16 Sweet Potato; 17 Ginger; 18 Gabi/Taro; 19 Thatch; 20 Bamboo; 21 Flowers; 22 String Beans; Other (Specify)

\begin{tabular}{|c|c|c|c|c|c|c|c|}
\hline & COMM.E.8 & COMM.E.9 & COMM.E.10 & COMM.E.11 & COMM.E.12 & COMM.E.13 & COMM.E.14 \\
\hline 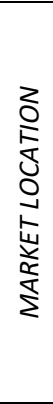 & Location & $\begin{array}{l}\text { What typical price } \\
\text { would you have } \\
\text { expected members } \\
\text { of your community } \\
\text { to get for } \\
\text { [CROPNAME] in } \\
\text { [LOCATION]? } \\
\text { Pesos/kg }\end{array}$ & $\begin{array}{l}\text { In the last } 12 \\
\text { months, what is the } \\
\text { lowest price people } \\
\text { in your community } \\
\text { received for } \\
\text { [CROPNAME] in } \\
\text { [LOCATION]? } \\
\text { Pesos/kg }\end{array}$ & $\begin{array}{l}\text { In the last } 12 \\
\text { months, what is the } \\
\text { highest price people } \\
\text { in your community } \\
\text { received for } \\
\text { [CROPNAME] in } \\
\text { [LOCATION]? } \\
\text { Pesos/kg }\end{array}$ & $\begin{array}{l}\text { What price would you have } \\
\text { expected members of your } \\
\text { community to get for } \\
\text { [CROPNAME] in } \\
\text { [LOCATION] this morning? } \\
\text { Pesos/kg }\end{array}$ & $\begin{array}{l}\text { Do you think members of } \\
\text { your community know the } \\
\text { price of [CROPNAME] } \\
\text { before selling in } \\
\text { [LOCATION]? } \\
0 \text { No } \\
1 \text { Yes }\end{array}$ & $\begin{array}{l}\text { Do you think members of } \\
\text { your community receive a } \\
\text { fair price for [CROPNAME] } \\
\text { when they sell in } \\
\text { [LOCATION]? } \\
1 \text { Very unfair } \\
2 \text { Unfair } \\
3 \text { Fair } \\
4 \text { More than fair } \\
5 \text { Very fair }\end{array}$ \\
\hline 01 & Same community & 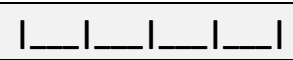 & 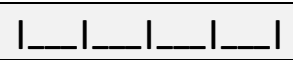 & 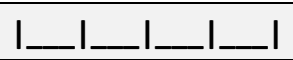 & I_I_I_I_I_I_ا_I & $\mathrm{I}$ & $I_{-}$ \\
\hline 02 & Neighboring Bgy. & 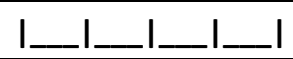 & 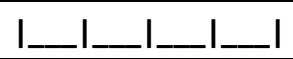 & 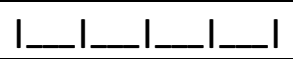 & I_I_I_I_I_I_I & $\mathrm{I}$ & $I_{-} I$ \\
\hline 03 & Baler & 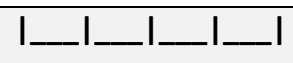 & 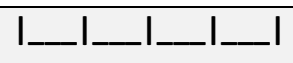 & 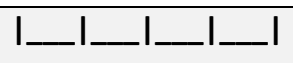 & 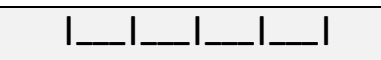 & $I_{\ldots} \mathrm{I}$ & $I_{\ldots} I_{1}$ \\
\hline 04 & Dingalan & 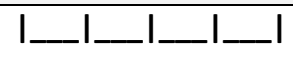 & 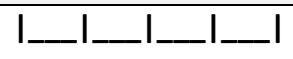 & 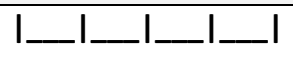 & 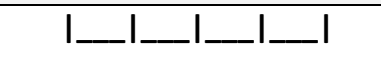 & $I_{\ldots} I$ & $I \ldots I$ \\
\hline 05 & Manila & 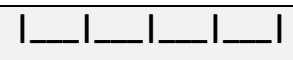 & 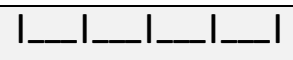 & 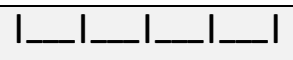 & 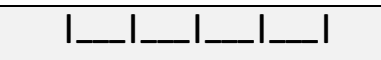 & $\mathrm{I}$ & $I_{\ldots} I$ \\
\hline
\end{tabular}




\begin{tabular}{|c|c|c|c|c|c|}
\hline COMM.E.15 & COMM.E.16 & COMM.E.17 & COMM.E.18 & COMM.E.19 & COMM.E.20 \\
\hline $\begin{array}{l}\text { Do any households } \\
\text { participating in fishing in } \\
\text { this sitio/barangay? } \\
0 \text { No >> } \\
1 \text { Yes }\end{array}$ & $\begin{array}{l}\text { What percentage of } \\
\text { households in this } \\
\text { sitio/barangay participates in } \\
\text { fishing? }\end{array}$ & $\begin{array}{l}\text { What are the main fish } \\
\text { varieties caught in this } \\
\text { sitio/barangay? } \\
\text { SEE FISH CODES }\end{array}$ & $\begin{array}{l}\text { During the past } 12 \text { months } \\
\text { what were the major fishing } \\
\text { months in this } \\
\text { sitio/barangay? } \\
\text { SELECT ALL APPLICABLE } \\
\text { MONTHS }\end{array}$ & $\begin{array}{l}\text { Where do people travel to } \\
\text { sell the fish that they have } \\
\text { caught? } \\
1 \text { To the same sitio/barangay } \\
2 \text { To the neighboring } \\
\text { barangay } \\
3 \text { To Baler } \\
4 \text { To Dingalan } \\
5 \text { To Manila } \\
6 \text { Elsewhere in the } \\
\text { Philippines } \\
7 \text { Outside of the Philippines }\end{array}$ & $\begin{array}{l}\text { If there is more than one } \\
\text { market, how do you think } \\
\text { people decide which market } \\
\text { to go to sell fish? }\end{array}$ \\
\hline 1 & I_I_I_I_L & 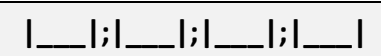 & 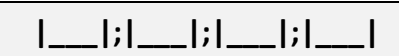 & 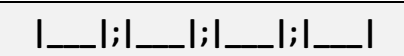 & I__ \\
\hline
\end{tabular}

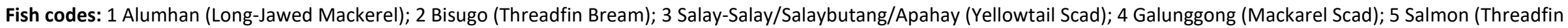

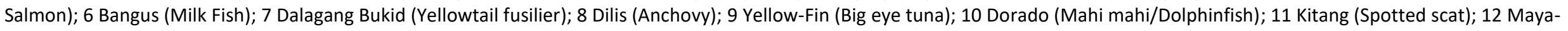

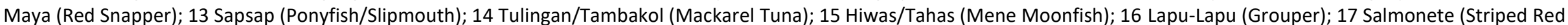
Mullet); 18 Tilapia; 19 Tawilis; 20 Crabs; 21 Shrimp; 22 Lobster; 23 Mussels; 24 Other Shellfish Other (Specify)

\begin{tabular}{|c|c|c|c|c|c|c|c|}
\hline & COMM.E.21 & COMM.E.22 & COMM.E.23 & COMM.E.24 & COMM.E.25 & COMM.E.26 & COMM.E.27 \\
\hline 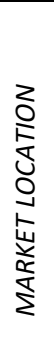 & Location & $\begin{array}{l}\text { What typical price } \\
\text { would you have } \\
\text { expected members } \\
\text { of your community } \\
\text { to get for [FISH] in } \\
\text { [LOCATION]? } \\
\text { Pesos/kg }\end{array}$ & $\begin{array}{l}\text { In the last } 12 \\
\text { months, what is the } \\
\text { lowest price people } \\
\text { in your community } \\
\text { received for [FISH] } \\
\text { in [LOCATION]? } \\
\text { Pesos/kg }\end{array}$ & $\begin{array}{l}\text { In the last } 12 \\
\text { months, what is the } \\
\text { highest price people } \\
\text { in your community } \\
\text { received for [FISH] } \\
\text { in [LOCATION]? } \\
\text { Pesos/kg }\end{array}$ & $\begin{array}{l}\text { What price would you have } \\
\text { expected members of your } \\
\text { community to get for [FISH] } \\
\text { in [LOCATION] this } \\
\text { morning? } \\
\text { Pesos/kg }\end{array}$ & $\begin{array}{l}\text { Do you think members of } \\
\text { your community know the } \\
\text { price of [FISH] before } \\
\text { selling in [LOCATION]? } \\
0 \text { No } \\
1 \text { Yes }\end{array}$ & $\begin{array}{l}\text { Do you think members of } \\
\text { your community receive a } \\
\text { fair price for [FISH] when } \\
\text { they sell in [LOCATION]? } \\
1 \text { Very unfair } \\
2 \text { Unfair } \\
3 \text { Fair } \\
4 \text { More than fair } \\
5 \text { Very fair }\end{array}$ \\
\hline 01 & Same community & 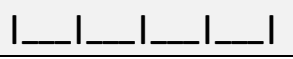 & 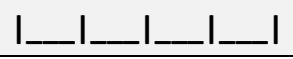 & 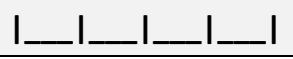 & I_I_ا_I_ا_I_ا_I & 1 & $I_{-} I$ \\
\hline 02 & Neighboring Bgy. & 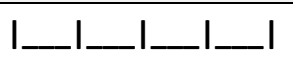 & 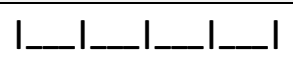 & 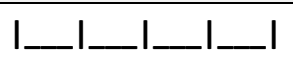 & 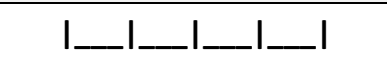 & $I$ & $I_{-}$ \\
\hline 03 & Baler & I_I_I_I_I_I & I_I_I_I_I_L_ & I_I_I_I_I_I & I_I_I_I_I_I_L_ & $I$ & 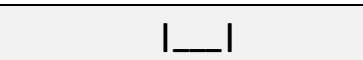 \\
\hline 04 & Dingalan & 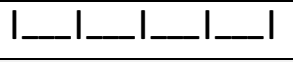 & 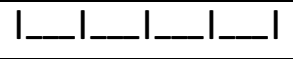 & 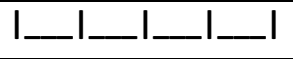 & I_I_I_I_I_I___ & $\mathrm{I}$ & I_I \\
\hline 05 & Manila & 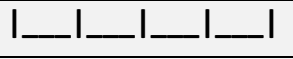 & I_I_I_I_I_I_L_ & I_I_l_l_l_ & 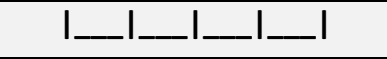 & $I_{-} I$ & $I$ \\
\hline
\end{tabular}


END OF THE SURVEY 